\title{
The ins and outs of professional skepticism
}

Citation for published version (APA):

Janssen, S. (2020). The ins and outs of professional skepticism: insights into the effects of professional skepticism traits on the inputs, process and outputs of the audit. [Doctoral Thesis, Maastricht University]. Maastricht University. https://doi.org/10.26481/dis.20200925sj

Document status and date:

Published: 01/01/2020

DOI:

10.26481/dis.20200925sj

Document Version:

Publisher's PDF, also known as Version of record

\section{Please check the document version of this publication:}

- A submitted manuscript is the version of the article upon submission and before peer-review. There can be important differences between the submitted version and the official published version of record.

People interested in the research are advised to contact the author for the final version of the publication, or visit the DOI to the publisher's website.

- The final author version and the galley proof are versions of the publication after peer review.

- The final published version features the final layout of the paper including the volume, issue and page numbers.

Link to publication

\footnotetext{
General rights rights.

- You may freely distribute the URL identifying the publication in the public portal. please follow below link for the End User Agreement:

www.umlib.nl/taverne-license

Take down policy

If you believe that this document breaches copyright please contact us at:

repository@maastrichtuniversity.nl

providing details and we will investigate your claim.
}

Copyright and moral rights for the publications made accessible in the public portal are retained by the authors and/or other copyright owners and it is a condition of accessing publications that users recognise and abide by the legal requirements associated with these

- Users may download and print one copy of any publication from the public portal for the purpose of private study or research.

- You may not further distribute the material or use it for any profit-making activity or commercial gain

If the publication is distributed under the terms of Article $25 \mathrm{fa}$ of the Dutch Copyright Act, indicated by the "Taverne" license above, 


\section{The INS AND OUts of Professional SKePticism}

INSIGHTS INTO THE EFFECTS OF PROFESSIONAL SKEPTICISM TRAITS ON THE INPUTS, PROCESS, AND OUTPUTS OF THE AUDIT 
The Ins and Outs of Professional Skeptisicm

Sanne Janssen, Antwerpen, 2020

Printed by: Universitas

(c) Sanne Janssen 2020

All rights reserved. No part of this book may be reproduced, stored in retrieval system, or transmitted in any form or by any means (including electronic, photocopying, recording, information storage and retrieval or otherwise) without permission in writing from the author. 


\title{
The Ins and Outs of Professional SKePticism \\ INSIGHTS INTO THE EFFECTS OF PROFESSIONAL SKEPTICISM TRAITS ON THE INPUTS, PROCESS, AND OUTPUTS OF THE AUDIT
}

\author{
DISSERTATION \\ to obtain the degree of Doctor at the Maastricht University, \\ on the authority of the Rector Magnificus, \\ Prof.dr. Rianne M. Letschert \\ in accordance with the decision of the Board of Deans, \\ to be defended in public \\ on 25 September 2020, at 14:00 hours \\ by \\ SANNE JANSSEN
}




\section{Supervisors}

Prof. dr. Ann Vanstraelen

Prof. dr. Kris Hardies, University of Antwerp, Belgium

\section{Assessment Committee}

Prof. dr. Jere Francis (Chairperson)

Prof. dr. Walter Aerts, University of Antwerp, Belgium

Prof. dr. Willem Buijink, Open University, the Netherlands

Prof. dr. Heidi Vander Bauwhede, Ghent University, Belgium 


\section{Professional Skepticism and Auditing}

A discourse goldmine

Conceived as a behavior, trait, and attitude

Behavioral theorists echo

Due professional care

Trait theorists caution Beware of recency bias

Attitude theorists?

Endorse critical assessment

Before taming audit risks

Before rotating audit firms

Or audit partners

Before adopting a questioning mind Assessing the auditors' frame of mind

Verify

Conservative-aggressive reporting

Managers engaging under pressure

Diligently

Scrutinized via an eye of presumptive doubt

And a lens of neutrality

Perceiving first their judgment

[...] as (un)trustworthy

Presuming next their accounting [...]

As (dis)honest

All the while

Walking on our profession's grey line When audits require (un)qualified judgments

When stakeholders request audit statements

Diligently engage in forensic-type audits

Since reports are legal testaments

Audit with presumptive mindsets

And at financial year ends

As accountable stewards

Reviewing audit decisions

When our judgments are final

We pause to ask auditors

"Did you trust, but verify?!"

(Ifeoluwa Tobi Popoola and Kazeem O. Akinyele, 2017) 



\section{SAMENVATTING}

Het doel van een externe audit is om zekerheid te bieden aan de gebruikers van de jaarrekening over de betrouwbaarheid van de gerapporteerde informatie. Een kwaliteitsvolle audit is dus van essentieel belang voor het functioneren van de kapitaalmarkten. Het toepassen van professioneel scepticisme wordt vaak omschreven als een belangrijke factor voor een kwaliteitsvolle audit. Echter, ondanks het vermeende belang, wordt het concept van professioneel scepticisme nog niet goed begrepen. Dit is, onder andere, het gevolg van onvoldoende onderzoek naar de gelijktijdige impact van persoonlijke en situationele karakteristieken. Samen met persoonlijke (bv. kennis, ervaring) en situationele karakteristieken (bv. tijds- en budgetdruk, audit kantoor), beïnvloeden professioneel sceptische karaktertrekken van een auditor het gedrag van de auditor. Dit proefschrift verbreedt ons begrip van professioneel scepticisme door professioneel sceptische karaktertrekken van een auditor te onderzoeken als inputfactoren, en drijfveren achter proces- en outputfactoren van de externe audit. De focus van dit proefschrift is dus op het inherent professioneel scepticisme van een auditor (d.w.z. de professioneel sceptische karaktertrekken), maar aangezien persoonlijke en situationele karakteristieken mede het gedrag van de auditor beïnvloeden, worden deze ook mee opgenomen.

De eerste studie, Hoofdstuk 2 van dit proefschrift, onderzoekt de antecedenten van professioneel sceptische karaktertrekken en test of deze karaktertrekken de auditor's attitude ten opzichte van sceptisch gedrag en intentie om zich sceptisch te gedragen, beïnvloeden. Het blijkt dat de professioneel sceptische karaktertrekken van een auditor significant worden beïnvloed door persoonlijkheidskenmerken en andere individuele verschillen. De resultaten tonen aan dat een sceptische auditor meer gewetensvol, open voor nieuwe ervaringen en narcistisch is, en minder psychopathisch. Verder blijkt dat ook geslacht en kennis een invloed hebben op de professioneel sceptische karaktertrekken, en dat deze karaktertrekken aanzienlijk verschillen tussen verschillende functies. Voorts geven de resultaten aan dat de professioneel sceptische karaktertrekken van een auditor positief geassocieerd zijn met de auditor's attitude ten opzichte van sceptisch gedrag, subjectieve norm met betrekking tot scepticisme (d.w.z. hoe iemand zich voelt bij en reageert op de druk van anderen om zich sceptisch te gedragen), waargenomen gedragscontrole (d.w.z. gepercipieerde moeilijkheid om sceptisch gedrag te vertonen) en intentie om sceptisch te handelen. Als laatste wordt onderzocht of deze inputfactoren (karaktereigenschappen, attitudes en intenties) uiteindelijk de auditkwaliteit beïnvloeden. De resultaten tonen aan dat deze inputfactoren positief verband houden met sceptische acties (bv. zoeken van informatie, het in twijfel trekken van bewijsmateriaal en het opschorten van oordeelsvorming bij het nemen van audit beslissingen). 
Uit de bevindingen van de eerste studie blijkt dat professioneel scepticisme een belangrijke inputfactor voor een kwalitatieve audit is. Echter is het niet duidelijk welke elementen van het auditproces beïnvloed worden door professioneel scepticisme en hoe professioneel scepticisme het auditproces beïnvloedt. Een belangrijk deel van het auditproces is het overwegen van de risico's op materiële afwijkingen in de jaarrekening als gevolg van fraude. Om de risico's zo goed mogelijk te kunnen inschatten, vereisen de auditing standaarden een bespreking met het auditteam over de fraude risico's (m.a.w. een fraude brainstorming sessie). Een tweede studie, Hoofdstuk 3 van dit proefschrift, onderzoekt dus de rol van professioneel scepticisme, meer bepaald van de professioneel sceptische karaktertrekken van een auditor, als drijfveer van de kwaliteit van de fraude brainstorming. De resultaten tonen aan dat meer sceptische partners een positief effect hebben op de kwaliteit van de fraude brainstorming. Meer bepaald zijn er meer specialisten aanwezig op en dragen die meer bij aan de fraude brainstorming sessie. Verder wordt er meer tijd besteed aan het voorbereiden van de sessie, duurt de sessie langer, en wordt er uitgebreider gediscussieerd over de mogelijkheden van fraude. De resultaten geven wel aan dat het effect van professioneel sceptische karaktertrekken van een auditor op de kwaliteit van de fraude brainstorming afhankelijk is van organisatorische factoren. Meer specifiek blijkt dat er een positief effect is als het audit kantoor een evaluatie systeem gebruikt dat professioneel scepticisme beloont en als het audit kantoor meer professioneel georiënteerd is.

De resultaten geven aan dat het inherent professioneel scepticisme van een auditor een belangrijke inputfactor is voor een kwalitatieve audit. Intuïtief lijkt het dus logisch dat de professioneel sceptische karaktertrekken van een auditor ook een effect zullen hebben op de output van een audit. Gezien de vereisten van de auditing standaarden om steeds professioneel scepticisme toe te passen en de gestandaardiseerde methodes voor het uitvoeren van een audit, is het echter niet zeker of het inherent professioneel scepticisme van een auditor een effect zal hebben op observeerbare audit uitkomsten (bv. de audit opinie). In een derde studie, Hoofdstuk 4 van dit proefschrift, wordt de relatie tussen de professioneel sceptische karaktertrekken van een auditor en de waarschijnlijkheid van een continuïteitsverklaring onderzocht. De resultaten tonen aan dat klanten, die in financiële moeilijkheden verkeren, van meer sceptische auditors meer kans hebben op het verkrijgen van een continuïteitsverklaring. Verder geven de resultaten aan dat situationele kenmerken (bv. klantengrootte, klantenrisico, duur van de partner-klant relatie) zelden invloed hebben op het effect van professioneel sceptische karaktertrekken van een auditor op de waarschijnlijkheid van een continuïteitsverklaring. Deze resultaten suggereren dat persoonlijkheid in de audit praktijk een belangrijke rol heeft. 
Samengevat, wordt aangetoond dat professioneel sceptische karaktertrekken van een auditor significant worden beïnvloed door persoonlijkheidskenmerken en andere individuele verschillen, en dat ze geassocieerd zijn met de auditor's attitude ten opzichte van sceptisch gedrag en intentie om sceptisch te handelen. Verder blijkt dat het toepassen van professioneel scepticisme de auditkwaliteit uiteindelijk zal beïnvloeden aangezien professioneel sceptische karaktertrekken van een auditor belangrijke drijfveren zijn van de auditproces- en outputfactoren. De holistische benadering die gebruikt wordt in dit proefschrift maakt het mogelijk om aanbevelingen te doen voor de praktijk om de toepassing van professioneel scepticisme te verbeteren.

Meer specifiek tonen de resultaten aan dat het belangrijk is om de juiste persoonlijkheid te vinden voor het audit beroep. Het is dus aangeraden aan audit kantoren om de persoonlijkheid te beoordelen tijdens het aanwerven (bv. door het gebruik van persoonlijkheidstesten) om uiteindelijk de mensen, die sceptische acties kunnen en durven ondernemen, aan te trekken en te behouden.

Verder kunnen de bevindingen van dit proefschrift de audit kantoren helpen bij het ontwerpen van effectieve interventies om het professioneel scepticisme van een auditor te verbeteren. Uit de resultaten van Hoofdstuk 2 blijkt dat de subjectieve norm (d.w.z. de sociale druk om zich sceptisch te gedragen) de sterkste voorspeller is van de auditor's intentie om sceptisch te handelen. Het toepassen van professioneel scepticisme kan dus verbeterd worden door de aanmoedigen van teamleden, en het goede voorbeeld van managers en partners. Voorts, geven de resultaten van Hoofdstuk 3 aan dat het prestatiebeoordelingssysteem het effect van professioneel sceptische karaktertrekken van een auditor op de kwaliteit van de fraude brainstorming beïnvloedt. Audit kantoren zouden bijgevolg hier rekening mee kunnen houden bij het ontwerpen van het evaluatie- en beloningssysteem. Een goed ontworpen evaluatie- en beloningssysteem kan het toepassen van professioneel scepticisme bevorderen.

Als laatste bieden de bevindingen van Hoofdstuk 3 waardevolle inzichten met betrekking tot de kwaliteit van de fraude brainstorming sessie. Op basis van deze bevindingen kunnen aanbevelingen gedaan worden om de kwaliteit van de fraude brainstorming te verbeteren. Meer specifiek wordt de aanwezigheid en deelname van specialisten en een uitgebreide discussie over hoe het management fraude zou kunnen plegen aanbevolen. 



\section{ACKNOWLEDGEMENT}

De voorbije jaren waren de mooiste en moeilijkste van mijn leven. Zowel op persoonlijk als professioneel vlak werden ze gekenmerkt door vele veranderingen. Een constante doorheen deze jaren was mijn doel om dit proefschrift af te werken. Dat was niet altijd vanzelfsprekend. Het was soms een uitdaging om gezien de vele veranderingen, en soms ook tegenslagen, gemotiveerd te blijven. Een woord van dank aan diegenen die mij, doorheen deze periode, gesteund, gemotiveerd en geholpen hebben, is dus zeker op zijn plaats.

Bedankt aan mijn promotoren, Kris en Ann. Ik heb al vaak gezegd dat ik erg veel geluk heb gehad met mijn promotoren. Ik heb enorm veel van jullie geleerd. Kris, ik was je eerste doctoraatstudent dus ik heb het gevoel dat we samen een hele weg hebben afgelegd. Vanaf het begin werd ik gemotiveerd door je passie en enthousiasme voor onderzoek. Je hebt er steeds alles aan gedaan om mij de beste kansen te geven en steun en begrip getoond op de moeilijke momenten. Ann, bedankt om mij de kans te bieden een dubbeldoctoraat te doen en op die manier veel bij te leren en interessante mensen te ontmoeten. Ongeacht hoe druk je het had, maakte je tijd om te luisteren, feedback en raad te geven. Bedankt voor jullie inspirerende passie en enthousiasme voor onderzoek, het delen van jullie ervaring, kennis en netwerk, en jullie begrip en steun tijdens de voorbije jaren. I also want to thank Karla Zehms for joining our FAR project, for giving me the opportunity to come to the University of Wisconsin-Madison and for sharing her experience and knowledge with me.

Bedankt aan mijn beoordelingscomité, Jere Francis, Walter Aerts, Willem Buijink, Ann Jorissen en Heidi Vander Bauwhede. Thank you all for your evaluation of my dissertation and the feedback. Thank you Jere for being the chair of my assessment committee. From the first time I saw you present at my first EAA, I was inspired by you as a researcher. Walter en Ann, bedankt om mij enkele jaren geleden de kans te geven te beginnen op het ACF departement en samen te werken. Heidi, bedankt voor jouw input en feedback vanaf het begin van mijn doctoraat. En als laatste Willem, bedankt om me nu de kans te geven om te werken aan de OU.

Bedankt aan mijn (ex)collega's. Gedurende de voorbije jaren heb ik veel mensen leren kennen verbonden aan verschillende universiteiten zowel aan Antwerpen en Maastricht, als aan Brussel, Leuven, Hasselt, en universiteiten over de hele wereld. Contact met collega's, zowel praten over

alledaagse dingen als praten over onderzoek en de bijhorende overwinningen, zorgen en frustraties, gaf me steeds energie en motivatie om verder te werken. 
Als laatste, maar zeker niet het minste, bedankt aan mijn familie en vrienden. Het leven is zoveel meer dan onderzoek. Bedankt om mij te steunen en samen met mij van het leven te genieten. Het gevoel ergens thuis en veilig te zijn en altijd ergens op terug te kunnen vallen is erg belangrijk. Het zorgt ervoor dat ik makkelijker kan relativeren en terug energie krijg en motivatie vind om verder te werken op moeilijke momenten.

Bedankt. 


\section{TABLE OF CONTENTS}

CHAPTER 1. GENERAL INTRODUCTION

1.1 INTRODUCTION

1.2 PROFESSIONAL SKEPTICISM

$\begin{array}{ll}1.3 \text { THIS DISSERTATION } & 9\end{array}$

CHAPTER 2. INPUT FACTORS 17

2.1 INTRODUCTION 18

2.2 LITERATURE REVIEW AND HYPOTHESES

2.3 METHOdOLOGY 28

2.4 RESULTS

2.5 CONCLUSIONS, LIMITATIONS AND DIRECTIONS FOR FUTURE RESEARCH

CHAPTER 3. PROCESS FACTORS 51

3.1 INTRODUCTION

3.2 LITERATURE REVIEW AND HYPOTHESIS

3.3 METHOdOLOGY

3.4 RESULTS $\quad 62$

3.5 ADDITIONAL ANALYSES $\quad 69$

3.6 CONCLUSIONS, LIMITATIONS AND DIRECTIONS FOR FUTURE RESEARCH 72

CHAPTER 4. OUTPUT FACTORS

$\begin{array}{ll}4.1 \text { INTRODUCTION } & 76\end{array}$

4.2 LITERATURE REVIEW AND HYPOTHESIS $\quad 79$

4.3 METHODOLOGY $\quad 82$

4.4 RESULTS

4.5 ADDITIONAL ANALYSES 93

4.6 CONCLUSIONS, LIMITATIONS AND DIRECTIONS FOR FUTURE RESEARCH 94

CHAPTER 5. GENERAL DISCUSSION 97

$\begin{array}{ll}5.1 \text { CONCLUSIONS } & 97\end{array}$

5.2 CONTRIBUTIONS AND PRACTICAL IMPLICATIONS 99

5.3 LIMITATIONS AND DIRECTIONS FOR FUTURE RESEARCH 100

REFERENCES

APPENDICES $\quad 121$

VALORIZATION ADDENDUM

$\begin{array}{ll}\text { CURRICULUM VITAE } & 137\end{array}$ 



\section{Chapter 1. General INTRODUCtion}

\subsection{INTRODUCTION}

An external auditor forms an opinion on the financial statements to provide assurance, to the users of the financial statements, on the quality of the reported information (i.e., provide a high level of assurance that the financial statements give a true and fair view). To form this opinion, the audit engagement team has to obtain sufficient appropriate audit evidence about whether the financial statements are free from material misstatements. The objective of the external audit is thus to give the users of financial statements confidence in the trustworthiness of the reported information. However, the users will only get confidence in the audited financial statements if they have confidence in the quality of the audit (i.e., trust that the audit is performed in accordance with the applicable auditing standards, laws, and regulations) (IAASB 2014).

Over the last decades, the quality of the performed audits is being questioned. The International Forum of Independent Audit Regulators (IFIAR) and its members, oversight bodies from all over the world, like the Public Company Accounting Oversight Board (PCAOB) in the United States, and the Authority Financial Markets (AFM) in the Netherlands, have investigated the performance of audit firms. The investigation reports show that audit firms deliver audits that contain a significant number of deficiencies, meaning that in a high number of audits, an opinion on the financial statements was formed even though there was not collected sufficient information to base their judgment on (e.g., AFM 2010, 2014; IFIAR 2014, 2015, 2016, 2017, 2018, 2019, 2020; PCAOB 2016, 2018, 2019b). In 2015, Lewis Ferguson, then Chair of IFIAR, concluded: "We continue to see these high levels of inspection deficiencies in vital areas of listed company audits. This is a problem for investors and other users of financial statements around the world. ... audit firms need to pursue initiatives to improve audit quality and the consistency of audit execution." (Ferguson 2015). The overall conclusion of these reports is that the audit profession is facing a structural problem (AFM 2014; IFIAR 2015), and although audit firms have invested in measures to improve audit quality in the past years, recent inspection findings show that improvement is slow (AFM 2017, 2019; IFIAR 2020).

To encourage audit firms to improve audit quality and to raise awareness of the key elements of audit quality, the International Auditing and Assurance Standards Board (IAASB) developed a Framework for Audit Quality (IAASB 2014). Audit quality is a complex subject, and there is no commonly accepted definition of audit quality (see Francis 2011; Knechel, Krishnan, Peyzner, 


\section{CHAPTER 1}

Schefchik, and Velury 2013). ${ }^{1}$ The Framework of the IAASB (2014) describes audit quality as the result of a combination of different input-, process- and output factors at engagement, audit firm, and national level, interactions with stakeholders, and contextual factors (see Figure 1.1).

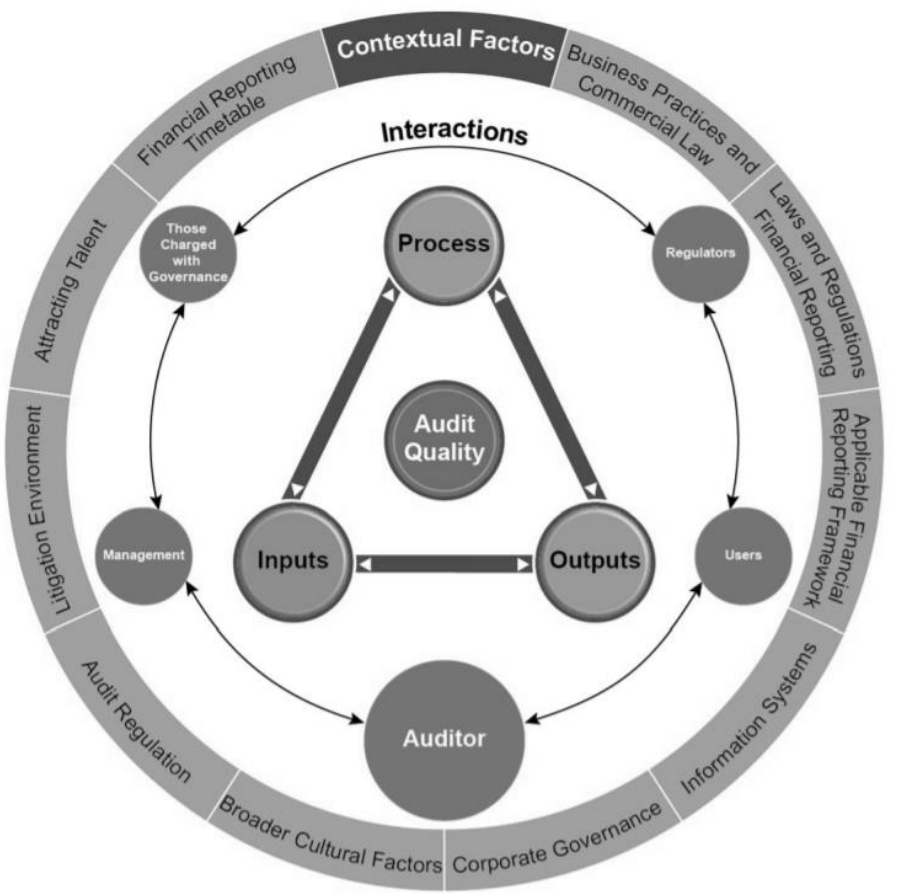

Figure 1.1 IAASB's Audit Quality Framework (IAASB 2014)

Both personal characteristics (e.g., the values, ethics, and attitudes of the auditor, the skills, and experience of the auditor) and situational characteristics (e.g., audit firm culture, and allocated time and budget) are considered as input factors. The process factors relate to the rigorousness of the audit process and quality control procedures, and the output factors include the auditor's report and other (in)visible outputs of the auditing process. The IAASB (2014, p. 6) concludes that "A quality audit is likely to have been achieved by an audit engagement team that exhibited appropriate values, ethics, and attitudes; was sufficiently knowledgeable, skilled, and experienced and had sufficient time allocated to perform the audit work; applied rigorous audit process and quality control procedures that complied with law, regulation and applicable standards; provided useful and timely reports; and interacted appropriately with relevant stakeholders."

\footnotetext{
${ }^{1}$ In the literature, multiple definitions of audit quality exist. DeAngelo (1981, p. 186) defined audit quality as "the marketassessed joint probability that a given auditor will both discover a breach in the client's accounting system, and report the breach". This is an example of a binary definition of audit quality (i.e., audit success or audit failure). Other authors have defined audit quality as continuous (i.e., ranging from low to high quality), for example DeFond and Zhang (2014, p. 275) define higher audit quality as "greater assurance of high financial statements quality".
} 
The Framework also describes the key attributes for a quality audit. One recurring key attribute is the exercise of professional skepticism. Following the IAASB (2014), personal skeptical characteristics like having a questioning mind, and being willing to challenge the judgments of other members of the engagement team or the client's management, and situational characteristics like coaching, on-the-job training, and tone at the top, which result in higher professional skepticism, are important input factors contributing to the quality of the audit. Further, the Framework describes that a rigorous audit process includes the exercise of professional skepticism. As the engagement team needs to comply with auditing standards, laws, and regulations, the application of professional skepticism throughout the planning and performance of the audit is required. If the audit methodology encourages the exercise of professional skepticism, the likelihood of a quality audit increases as maintaining professional skepticism throughout the audit process allows the auditor to better assess the risk of material misstatement in an entity's financial statements, assess the sufficiency and appropriateness of audit evidence, and reach appropriate conclusions (IAASB 2014).

Professional skepticism is often emphasized as a key input to audit quality by regulators and standard setters (e.g., AFM 2014; IAASB 2015; IFIAR 2015; PCAOB 2015). For example, IFIAR concluded from its 2014 Survey of Inspection Findings that: " $A$ factor underlying many audit deficiencies is insufficient exercise of professional skepticism during performance of the audi"' (IFIAR, 2015, p. 3). ${ }^{2}$ Hence, "IFIAR has suggested that enhanced professional skepticism by auditors will contribute significantly to improve the quality of the audit and that firms should prioritize efforts in this area" (IAASB, 2015, p. 12).

\subsection{PROFESSIONAL SKEPTICISM ${ }^{3}$}

Professional skepticism is definitely not a new theme, but it has rapidly increased in importance over the past decade(s). Reference to the concept of professional skepticism before the 1990s is close to non-existent. The first reference in US auditing standards to the concept of professional skepticism dates from the late 1980s. ${ }^{4}$ During the 1990s there was increased attention for professional skepticism both by regulators and standard setters (e.g., GAO 1996; AICPA 1997 (SAS No. 82); IAASB 1998 (ISA 240)) as well as by academics (e.g., McMillan and White 1993;

\footnotetext{
${ }^{2}$ According to a study by Beasley, Carcelly, Hermanson, and Neal (2013), insufficient levels of professional skepticism were amongst the top reasons for SEC sanctions against auditors over the period 1998-2010 related to instances of alleged fraudulent financial reporting by US public companies (cited in 49 of the 81 cases).

3 This section is based on Hardies, K., and S. Janssen. 2017. FAR research project: Professional skepticism: a trending concept in need of understanding. Maandblad voor Accountancy en Bedrijfseconomie 91(9):274-280.

${ }^{4}$ SAS No. 53 (The Auditor's Responsibility to Detect and Report Errors and Irregularities, 1988).
} 
Shaub 1996), but professional skepticism only started to get real attention after the turn of the century (due to the unraveling of a series of high-profile accounting scandals including Enron and WorldCom). Within important practitioner journals like CPA Journal and Journal of Accountancy professional skepticism got linked to audit failures (Carmichael and Craig 1996), SEC enforcement actions (Beasley, Carcello, and Hermanson 2001), and malpractice claims against auditors (Anderson and Wolfe 2002). Between 2000 and 2010, academics increased their focus on professional skepticism (e.g., Nelson 2009; Hurtt 2010; Rennie, Kopp, and Lemon 2010). Only in more recent years, however, professional skepticism became the trending topic that it is today. After the financial crisis, regulators and standard setters throughout the world devoted significant attention to the issue of professional skepticism. For example, in June 2010 the Financial Services Authority (FSA) and the Financial Reporting Council (FRC) issued a discussion paper which questions whether the auditor has always been sufficiently skeptical. In December 2012, the PCAOB issued a staff audit practice alert on professional skepticism. In December 2015, the IAASB solicited comments on their project Enhancing Audit Quality in the Public Interest: A Focus on Professional Skepticism, Quality Control and Group Audits. This increased attention to professional skepticism by practitioners is also reflected in the academic attention devoted to the subject.

Despite its alleged importance and popularity both among academics and practitioners, the concept of professional skepticism is in fact not well understood. Standard setters typically define professional skepticism as "an attitude that includes a questioning mind and a critical assessment of audit evidence" (ISA 200; AS 1015). Many academics view professional skepticism as an attitude (i.e., as a state) (e.g., Shaub 1996; Nolder and Kadous 2018; Robinson, Curtis, and Robertson 2018). However, academics have also defined professional skepticism in terms of (relative) stable individual differences between individuals (i.e., as a trait) (e.g., Hurtt 2010; Quadackers, Groot, and Wright 2014). Importantly, professional skepticism is an important input to auditors' judgment and decision-making and is thought to be of value because it enhances audit quality (e.g., Nelson 2009; IAASB 2015). Hence, professional skepticism should be apparent from the behavior displayed by the auditor. For example, if an auditor maintains professional skepticism throughout the audit, this should be reflected in "a heightened assessment of the risk that an assertion is incorrect, conditional on the information available to the auditor" (Nelson 2009, p. 1). As such, professional skepticism could be related to, for example, increased fraud detection, lower levels of earnings management, higher likelihood of GCO, lower materiality levels, more frequent audit adjustments, or less reliance on management explanations and evidence. 


\section{Professional Skepticism as a Trait}

As indicated above, research on professional skepticism is relative recent, but has seen a rapid expansion over the last few years. Most of this research has tended to treat professional skepticism as a trait. Traits refer to individual characteristics which are generally unaffected by the environment and consequently relatively stable (Fleeson 2017; John, Robins, and Pervin 2008; McCrae and Costa, 1995). As a trait, professional skepticism can be understood as "the propensity of an individual to defer concluding until the evidence provides sufficient support for one alternative/explanation over others" (Hurtt 2010, p. 151). If professional skepticism is a trait, this means that within every individual, there is some baseline level of professional skepticism that the individual is willing to extend to nearly all those situations/engagements in which the individual interacts. In this context, some authors also understand professional skepticism as the opposite of trust (Shaub 1996), being the propensity to trust (nearly all) those with whom one interacts and a general tendency to make positive attributions about others' intentions (Rotter 1954, 1967).

Drawing on this conceptualization of professional skepticism as a trait, measured by the Hurtt Professional Skepticism Scale (HPS; Hurtt 2010), Hurtt, Eining, and Plumlee (2012) experimentally find that auditors who score high on the HPS Scale detect more contradictions in working papers and generate more alternative explanations for management assertions. Similarly, Quadackers et al. (2014), using the inverse of trust to measure professional skepticism, show that less trusting auditors are more likely to arrive at skeptical judgments in an audit task. This finding mirrors earlier work in the field which found that less trusting auditors pay more attention to instances of aggressive financial reporting in financial statements and, as a result, are more likely to arrive at judgments of intentional misstatement (Rose 2007).

In addition to drawing on psychometric measures such as the HPS Scale or the Rotter Interpersonal Trust Scale (RIT; Rotter 1967), accounting researchers have investigated the effect of professional skepticism by investigating how management reacts to changes in auditor behavior that are indicative of an increase in auditor skepticism such as a change in audit procedures. For example, Chen, Kelly, and Salterio (2012) show experimentally that managers expect less earnings management to occur if they are made aware of the fact that auditors changed the nature of evidence collected toward more probative evidence. Collectively, these studies suggest that professional skepticism, whether operationalized as a trait or inferred from skeptical actions, is consistently linked with beneficial audit outcomes such as deterring earnings management on part of the client or more skeptical judgments and actions on part of the auditors. 


\section{Professional Skepticism as a State}

In addition to being a trait, professional skepticism can also be understood as an emergent state (Grohnert, Meuwissen, and Gijselaers 2018; Nolder and Kadous 2018; Robinson et al. 2018). Emergent states refer to cognitive, motivational, and affective states that are dynamic and vary as a function of situational characteristics as well as inputs, processes, and outcomes (Marks, Mathieu, and Zaccaro 2001). If professional skepticism is a state, this means that professional skepticism can be understood primarily as an attitude which can develop over time based on situational characteristics and need. This also implies that professional skepticism is not just an input, but could be a proximal outcome as well depending on the context (see Marks et al. 2001). For example, professional skepticism may be viewed as an input to fraud risk assessment, but may also be viewed as a proximal outcome of the interaction between a junior team member and the audit partner (e.g., during fraud brainstorming). Most importantly, this means that professional skepticism can be enhanced or impeded due to specific interactions (e.g., due to interaction with an audit partner that heavily stresses the importance of professional skepticism) or due to specific organizational conditions (e.g., due to severe time budget pressure).

In the existing literature, this aspect of professional skepticism as an emerging state is covered by studies that either investigate how situational characteristics at the level of the audit/client firm or auditor characteristics, such as experience and expertise, enable or constrain the exercise of professional skepticism. Regarding situational characteristics, there is a relatively strong consensus in the empirical literature that they can constrain or facilitate an auditor's exercise of professional skepticism. These studies can be broadly classified into those investigating situational characteristics at the level of the audit firm or audit team, and those considering factors in the client environment. Regarding the internal environment of the audit firm, Nelson, Proell, and Randel (2016) show that auditors who perceive their team leader to be more team-oriented are more likely to speak up and raise audit issues (i.e., engage in skeptical actions). Similarly, it has been shown that auditors whose audit partner stresses the importance of professional skepticism are more efficient and effective in the identification of relevant fraud risks as well as in their choice of relevant audit procedures (Carpenter and Reimers 2013). Partners can further trigger an increase in professional skepticism by highlighting that client management believes there to be a low risk of fraud (Harding and Trotman 2017). With regard to the external client environment, prior research has found that auditors confronted with either a weak control environment or overly optimistic management assertions arrive at more skeptical judgments and engage in more skeptical actions (Quadackers et al. 2009, 2014; Feng and Li 2014). In contrast to the relatively consistent findings regarding situational characteristics at the audit team and client level, findings 
related to the role of auditor experience and expertise on the exercise of professional skepticism are mixed. On the one hand, studies such as Rose (2007) find a direct, positive effect of (fraud) experience on the likelihood of arriving at a skeptical judgment regarding a potential misstatement. On the other hand, Grenier (2017) finds that non-industry specialist auditors are, in general, more skeptical than their specialist colleagues, calling into question the value of industry training and specialization from an audit quality perspective.

\section{Interaction Between Trait and State}

A potential reconciliation of these contradictory findings lies in the detailed study of the interactions between trait professional skepticism and the situational characteristics that promote professional skepticism as an emergent state (e.g. Grohnert et al. 2018). For example, Quadackers et al. (2014) find that auditors exhibiting a low level of dispositional trust will issue more skeptical judgments if the client has a weak internal control system compared to an auditor exhibiting high levels of dispositional trust. Consequently, it seems that auditors exhibiting a high level of trait professional skepticism are more likely to be triggered by situational characteristics that influence professional skepticism as an emergent state. There is thus considerable value in investigating how trait professional skepticism can potentially be impeded or facilitated by situational characteristics that are associated with triggering professional skepticism as an emergent state. Therefore, researchers have concluded that professional skepticism has both a trait and a state component. Some people might be "professional skeptic" (trait) (i.e., have an inherent tendency towards professional skepticism), but nevertheless on a specific occasion be "convinced" (state) easily by the evidence presented by management (i.e., be in a state of believing), which makes them "fail to demand" (behavior) more proof for a certain assertion. Overall, research indicates that traits interact with different factors to create many emotional states, and the temporary ways of being or feeling affect our behavior (modelled in Figure 1.2).

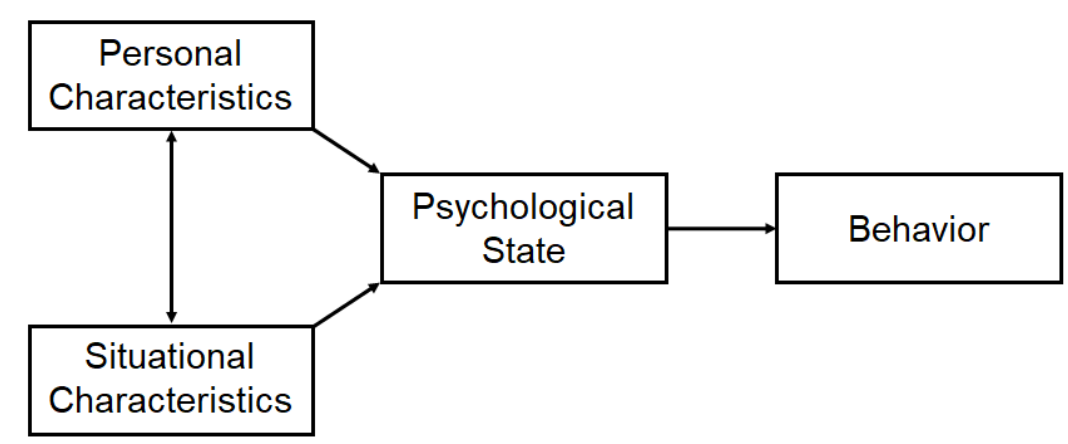

Figure 1.2 Conceptualizing Professional Skepticism 


\section{CHAPTER 1}

This implies that (a) different people will react differently (i.e., behave differently) to different situational cues, but also that (b) situations will have a different effect on behavior depending on the characteristics (e.g., traits) of people.

The conceptualization of professional skepticism as an interaction between personal and situational characteristics, creating a psychological state which affects the auditor's behavior, is an integration and extension of previous models of professional skepticism. Nelson (2009) models professional skepticism in audit outcomes as a consequence of the way in which auditor traits (e.g., professional skepticism traits, individual differences), knowledge (e.g., knowledge of audit standard), and incentives (e.g., time-budget pressure, tone at the top) combine to affect auditor judgments and actions. The professional skepticism framework of Hurtt (2010) presents professional skepticism as a multi-dimensional individual characteristic where trait skepticism and state skepticism (aroused by situational characteristics) form a skeptical mindset which in turn affects skeptical behavior. Hurtt et al. (2013) identified several factors that might be incrementally important to the Nelson (2009) model, particularly with respect to antecedents to skeptical judgment and skeptical action. Evidential input affects skeptical judgment which is also influenced by individual auditor characteristics (e.g., professional skepticism traits, individual differences), client and environmental characteristics (e.g., audit firm culture, financial incentives), and knowledge. Glover and Prawitt (2013) likewise view professional skepticism as arising from a combination of personal traits, knowledge, and skills. Nolder and Kadous (2018) conceptualize professional skepticism as a combination of both a skeptical mindset and a skeptical attitude which is influenced by individual determinants (e.g., personality, knowledge, motivation) and situational determinants (e.g., firm culture, client pressure, firm methodology). In their model, professional skepticism is reflected in auditor judgments, feelings and actions.

A common feature of all of these conceptualizations is that auditors possess some relatively stable traits, or predispositions, that affect the extent to which they behave and act skeptically in a particular audit situation. As widely established in personality psychology, such traits are important in explaining attitudes and behaviors (John et al. 2008; McCrae and Costa, 1995). Further, all these models acknowledge, to varying degrees, the importance of situational characteristics in skeptical behavior. 


\subsection{THIS DISSERTATION}

The literature on professional skepticism has rapidly been increasing over the past few years. However, despite some excellent theoretical work in this area (Hurtt, 2010; Nolder and Kadous 2018; Robinson et al. 2018) and the publication of a number of review studies on the subject matter (Nelson 2009; Hurtt, Brown-Liburd, Earley, and Krishnamoorthy 2013), our understanding of professional skepticism remains limited and underdeveloped due to the lack of prior research that simultaneously considers the impact of personal and situational characteristics and the intermediating role of psychological states. Although prior research suggests that professional skepticism should be understood as both a trait and state concept (i.e., professional skepticism is the outcome of both stable, enduring features and of contingent factors), the relative importance of personal and situational characteristics remains unknown. Additionally, we have no systematic evidence on the importance of various situational characteristics that allegedly could threaten the maintenance of professional skepticism during an audit (e.g., various organizational and environmental conditions such as tone at the top, commercialization, quality control procedures, promotion and compensation processes, client importance). ${ }^{5}$ We also lack a thorough understanding of the individual antecedents of professional skepticism (e.g., is professional skepticism as a trait associated with certain socio-demographic factors, experience, motivation, or personality). Further, the consequences of professional skepticism on various audit processes and audit outcomes are badly understood. It is assumed that professional skepticism fosters audit quality, but it is unclear which elements of the audit process are affected by professional skepticism. For example, does professional skepticism affect any of the following elements:

\footnotetext{
${ }^{5}$ Regulators and standard setters as well as the popular press have claimed that professional skepticism could be affected by a diverse set of organizational conditions and other situational characteristics such as a firm's quality control systems (including the tone at the top, performance, promotion, and compensation processes), workload and time budget pressures, incentives to maintain client relationships and avoid conflicts with management, identification with the client and trust in management, and the nature and volume of non-audit services (e.g., FRC 2012; PCAOB 2012; Richards 2016). There exists a reasonable amount of research on the impact of organizational conditions and environmental factors on various aspects of the audit process and audit quality. Especially the role of non-audit services has attracted a great deal of researcher attention (for an overview, see Sharma 2014), but also other factors such as audit time pressure and audit partner busyness (Goodwind and Wu 2016; Malone and Roberts 1996), the degree to which auditors identify with their client versus their identification with the audit profession (Bamber and lyer 2002, 2007), the strength of the audit firm's internal quality control and review system (e.g., Malone and Roberts 1996), and the audit firm's internal error reporting climate (Gronewold and Donle 2011; Gold, Gronewold, and Salterio 2014) have been investigated in the literature. The role of such factors in relationship with professional skepticism has, however, received scant attention from researchers to date. Some of the notable exceptions highlighted in this paper include investigations on the role of partner communications on auditor professional skepticism (Carpenter and Reimers 2013; Harding and Trotman 2017), partner characteristics on the likelihood that audit team members will speak up and raise audit issues (Nelson et al. 2016), and the influence of the clients control system on skeptical judgments (Quadackers et al. 2009, 2014).
} 
materiality levels, audit planning, fraud brainstorming, risk identification, risk assessment, audit testing, the evaluation of identified material misstatements, the audit reporting process? The objective of this dissertation is to advance our understanding of professional skepticism by investigating the effects of professional skepticism on the inputs, process, and outcomes of the audit by means of reporting the results of three empirical studies (modelled in figure 1.3).

\section{Professional Skepticism}

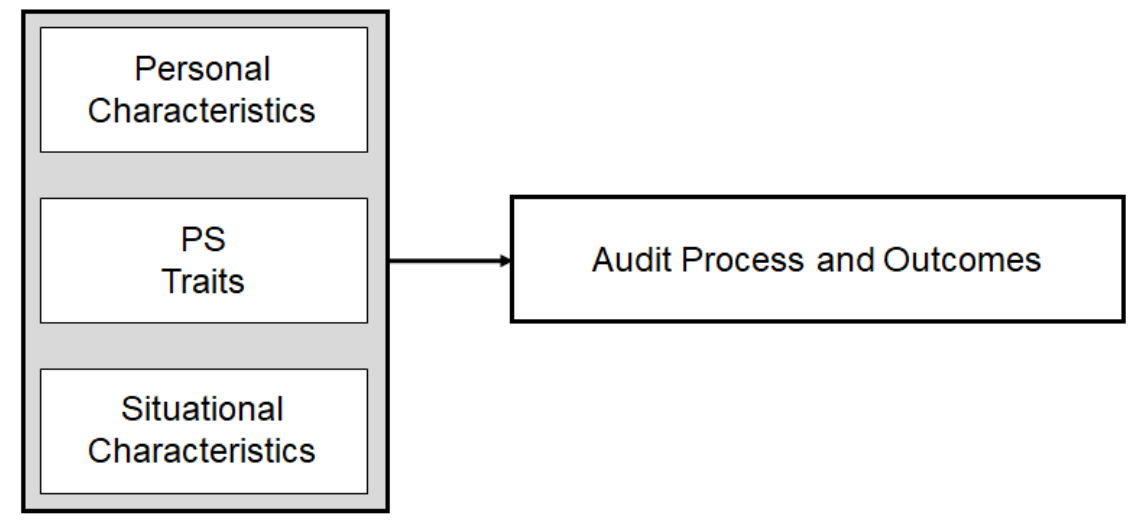

Figure 1.3 Conceptual Model Dissertation

Professional skepticism has both a trait and a state component. The focus of this dissertation is on the professional skepticism traits of the auditor to investigate the importance of inherent professional skepticism. Personal and situational characteristics are included as control variables to disentangle the effect of trait and state skepticism. ${ }^{6}$ The first empirical study looks into professional skepticism as an input factor for audit quality. The effect of professional skepticism on (a part of) the audit process is examined in a second empirical study, and in the third empirical study, the effect of professional skepticism on audit output is investigated.

\section{Input Factors}

The first empirical study, Chapter 2 of this dissertation, investigates the antecedents of professional skepticism traits, and tests the effect of these traits on the attitude and intention towards skeptical behavior (see Figure 1.4). To explore whether these input factors (traits, attitudes, and intentions) will ultimately affect audit quality, the study examines their collective association with skeptical actions with respect to evidence collection and evaluation while controlling for situational characteristics. The study consists of three phases to explore these different relationships. Phase I considers the effects of individual differences (gender, experience,

${ }^{6}$ The role of psychological states is outside the scope of this dissertation. 
and knowledge) and personality traits (Big 5 and Dark Triad indicators of personality) on professional skepticism traits. Based on prior literature, the score of the auditor on the Hurtt Professional Skepticism Scale (HPS, Hurtt 2010), the Professional Moral Courage Scale (PMC, Sekerka, Bagozzi, and Charnigo 2009), and Rotter's Interpersonal Trust scale (reversed, RIT, Rotter 1967; Wrightsman 1991) are used to capture three professional skepticism traits (professional skepticism, moral courage, and distrust). Phase II advances the Theory of Planned Behavior (Ajzen 1991, 2005, 2012), which researchers use to explain and predict human behavior, in the context of auditor professional skepticism. The Theory of Planned Behavior is extended with professional skepticism traits as antecedents of attitudes about behaving skeptically, subjective norms with respect to the social pressure to behave skeptically, and perceived behavioral control to behave skeptically. It is hypothesized that auditors with higher professional skepticism traits have a more positive attitude towards professional skepticism, and a stronger intention to take skeptical actions. Phase III completes the model, and links the skeptical intention to skeptical actions while controlling for situational characteristics. A positive associations between the auditors' skeptical intentions and skeptical actions with respect to searching for evidence, questioning its veracity, and suspending judgment until evidence search and analysis search concludes, is hypothesized.

\section{Professional Skepticism}

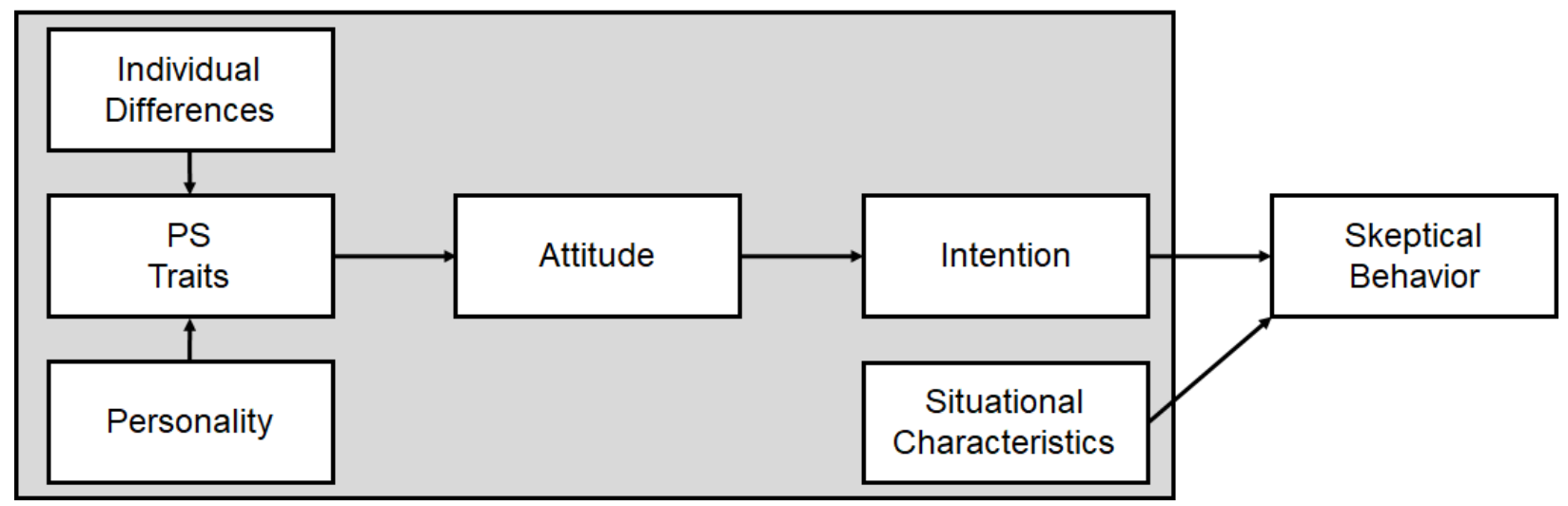

Figure 1.4 Conceptual Model Chapter 2

To investigate these associations, data were obtained from Dutch audit firms via the Foundation for Auditing Research (FAR). CenterData provided anonymized and transformed responses from six audit firms in the Netherlands and 663 auditors across all ranks who responded to an experiential questionnaire about one of their actual engagements (see Appendix IV). To investigate the conceptual model, a Confirmatory Factor Analysis was conducted to 
establish a valid and reliable measurement model and then a full Structural Equation Modelling analyses was conducted to test the associations hypothesized in the research model.

\section{Process Factors}

The results presented in Chapter 2 of this dissertation suggest a positive association between skeptical traits, attitudes, and intentions and skeptical actions. These findings support the assumption that professional skepticism is an important input factor to the audit process to support a quality audit (IAASB 2014). However, it is unclear which elements of the audit process are affected by professional skepticism and how professional skepticism affects these processes.

An important part of the audit process is the consideration of the risks of material misstatements due to fraud (e.g., ISA 240). Auditing standards require a discussion among the engagement team regarding these risks (i.e., fraud brainstorming). Fraud brainstorming quality enables the identification of fraud risk factors and associated audit responses (Carpenter 2007, Hoffman and Zimbelman 2009; Lynch, Murthy, and Engle 2009; Trotman, Simnett, and Khalifa 2009; Chen, Trotman, and Zhou 2015). Thus, higher fraud brainstorming quality leads to better fraud risk identification and more effective audit plans to identify misstatements due to fraud, and consequently, indirectly affects audit quality.

Although auditing standards emphasize the need for auditors to exercise professional skepticism, especially when considering the risk of material misstatements due to fraud (e.g., AS 2110; ISA 240; SAS. No. 99), a lack of professional skepticism is regularly cited in inspection reports as a problem for auditors' fraud assessments (e.g., PCAOB 2008). Therefore, the second empirical study, Chapter 3 in this dissertation, examines the role of professional skepticism as a driver of fraud brainstorming quality (see Figure 1.5).

\section{Professional Skepticism}

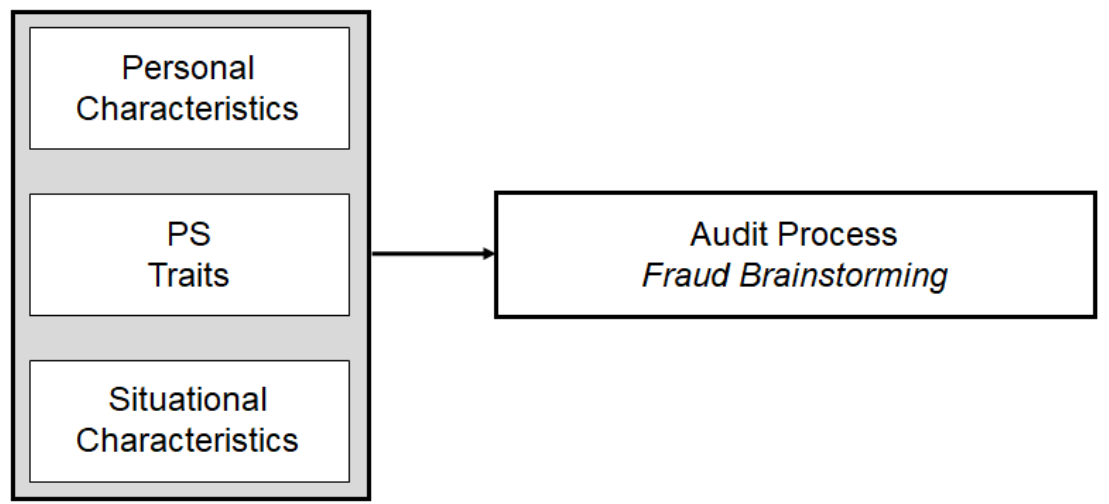

Figure 1.5 Conceptual Model Chapter 3 
An OLS regression model is estimated to examine the effect of professional skepticism traits on fraud brainstorming quality and its underlying factors (i.e., attendance and communication, fraud brainstorming structure and timing, and engagement team effort). Three professional skepticism traits are considered (HPS, PMC, and RIT) and fraud brainstorming quality is measured by the fraud brainstorming quality measure of Brazel, Carpenter, and Jenkins (2010). The data were obtained from the FAR, which provided anonymized and transformed responses from five audit firms in the Netherlands and 185 partners who responded to an experiential questionnaire about one of their actual engagements (see Appendix IV).

\section{Output Factors}

As discussed above, independent public oversight bodies have repeatedly expressed concerns on the level of professional skepticism as a factor underlying many audit deficiencies (e.g., IFIAR 2012, 2015). It is argued that enhancing professional skepticism contributes significantly to quality audits (e.g., IFIAR 2015). Prior experimental research has investigated associations between professional skepticism and auditor judgments and decisions (e.g., Bowlin, Hobson, and Piercey 2015; Quadackers et al. 2014; Rose 2007), but there is very limited archival evidence that contextualizes these findings. The results, reported in Chapter 2 and Chapter 3 , suggest that the inherent professional skepticism of an auditor is a key input factor of audit quality and an important driver of the audit process. Thus, it seems intuitive that variations in trait skepticism would also drive audit outcomes. However, whether differences in trait skepticism have small or large effects on audit outcomes remains an empirical question. Further, various factors within an audit engagement (investigated in isolation in experimental settings) can offset or interact with each other in creating audit outcomes (Aobdia 2019; Nelson 2009). Given that auditing standards require all auditors to exercise professional skepticism for each engagement, it is not clear whether professional skepticism traits of audit partners are predictive of actual audit outcomes in audit practice. Furthermore, audit firms have standard methodologies in place for conducting an audit, and the auditor's work is subject to engagement quality control review (e.g., ISQC1). Hence, whether higher or lower levels of individual auditor's professional skepticism ultimately affect publicly observable audit outcomes is an empirical question. Therefore, the third empirical study, Chapter 4 in this dissertation, investigates the relationship between auditors' professional skepticism traits and audit output (see Figure 1.6). 
Professional Skepticism

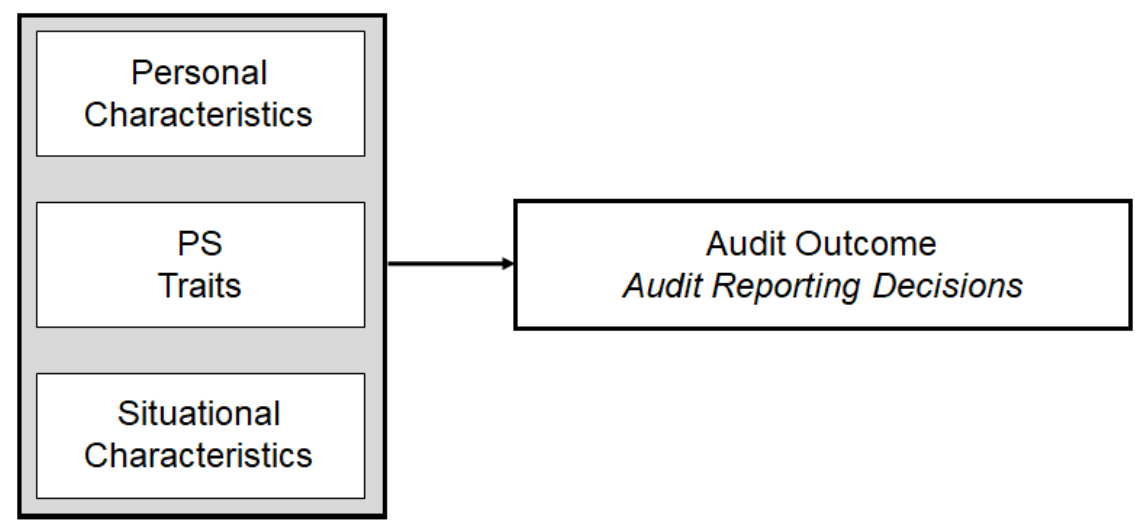

Figure 1.6 Conceptual Model Chapter 4

To investigate this relation, survey data on individual auditors are combined with publicly available, archival data from Belgium (see Appendix IV). Regression models are estimated to examine the effect of professional skepticism traits (HPS, PMC and RIT) on audit opinions.

\section{Setting}

The studies in this dissertation are based on Dutch (Chapters 2 and 3) and Belgian (Chapter 4) data. The Netherlands and Belgium are two European Union (EU) member states. Given that the EU provides regulations on auditing to improve the integrity of financial statements, the two countries have comparable audit regulations and audit markets (Van Linden and Hardies 2018). ${ }^{7}$ The International Standards on Auditing (ISA's) of the International Auditing and Assurance Standards Board (IAASB) are adopted without modifications by the professional bodies in the two countries (i.e., the Royal Netherlands Institute of Chartered Accountants (NBA) and the Belgian Institute of Registered Auditors (IBR)). The Dutch Authority for the Financial Markets (AFM) and the Belgian Financial Services and Markets Authority (FSMA) are responsible for overseeing the audit market. Information on the registered external auditors (i.e., the auditors who have taken the oath and are allowed to sign the audit report) and the audit firms (i.e., the firms who are allowed to perform an external audit) can be found in the AFM register for 1800 Dutch auditors and 274 Dutch audit firms, and in the IBR register for 1024 Belgian auditors and 581 Belgian audit firms (numbers as of February 7,2020).

\footnotetext{
7 To reinforce auditors' independence and their professional skepticism an amending directive (Directive 2014/56/EU) that sets out the framework for all statutory audits, strengthens public oversight of the audit profession and improves cooperation between competent authorities in the EU, and a regulation (Regulation No 537/2014) that specifies requirements for statutory audits of public interest entities (PIEs), such as listed companies, banks and insurance undertakings, were adopted in 2014.
} 
In addition to a highly regulated supply, there is also a highly regulated demand for audit services in both countries. Companies are required to have their financial statements audited by a registered auditor if they meet certain size criteria (in accordance with EU directives). ${ }^{8}$ The thresholds of these criteria are rather low and therefore many relatively small companies are subject to a statutory audit. As a result, both in the Netherlands and Belgium, more than 99 percent of the companies that are required to appoint an external auditor are private companies. For many privately held companies, the demand for audit services is thus not voluntary. This leads to 19,870 statutory audit engagements per year in the Netherlands (AFM) and 28,560 statutory audit engagements per year in Belgium (FSMA).

\section{Outline $^{9}$}

Chapter 5 concludes this dissertation with a synthesis of findings across the three empirical studies, including a discussion of limitations, an agenda for future research and an overview of the implications for practice.

\footnotetext{
8 The thresholds are different in various EU countries. In the Netherlands, a company is considered large if they meet at least two of the following criteria: (1) turnover (excluding VAT) $>12,000,000$ euros; (2) total assets $>6,000,000$ euros; and (3) number of employees (yearly average) $>50$. The thresholds in Belgium are lower: (1) turnover (excluding VAT) >7,300,000 euros; (2) total assets > 3,650,000 euros; and (3) number of employees (yearly average) $>50$. These criteria must be considered on a consolidated basis if the company belongs to a group that publishes consolidated statements or if the company is a holding or a listed company. Listed companies and companies with more than 100 employees are always considered large.

${ }^{9}$ Note: This dissertation is a collection of related studies. Because each study is written to be read on its own, repetition and overlap between the chapters in inevitable.
} 



\title{
CHAPTER 2. INPUT FACTORS
}

\begin{abstract}
Auditors' professional skepticism is critical to applying auditing standards and achieving audit quality. Prior research provides measures of skepticism in general, and auditor-specific trait skepticism. Other research develops and tests a theoretical model of auditor professional skepticism, positing factors that contribute to skeptical intentions and skeptical actions. In this chapter, we provide an empirical test of these measures and theories, examining individual differences and personality traits that affect trait-based professional skepticism, testing the associations between factors related to behavioral intentions toward skepticism, and revealing their collective association with skeptical actions. We use data from a sample of 663 auditors across all ranks from staff through partner who each complete an experiential questionnaire relating to one of their actual audit engagements. We find that individual differences (gender, experience, and knowledge) are associated with differential levels of professional trait skepticism, as are personality traits (agreeableness, conscientiousness, openness, narcissism and psychopathy). Advancing the Theory of Planned Behavior in an auditing context, the results reveal that trait skepticism is positively associated with attitudes, subjective norms, and perceived behavioral control over skepticism, which in turn affect auditors' intentions to act skeptically. Subjective norms are the strongest predictor of auditors' skeptical intentions. Further, attitudes, subjective norms, and perceived behavioral control are positively associated with skeptical actions with respect to evidence collection and evaluation, and intentions to act skeptically positively mediate these associations..
\end{abstract}

This chapter is based on a working paper with Kris Hardies, Ann Vanstraelen, and Karla Zehms.

We would like to thank the Foundation for Auditing Research for their grant $2016 \mathrm{~B} 05$. Furthermore, we would like to thank all participants and data providing firms. The views expressed in this chapter are our views and do not necessarily reflect the views of the Foundation for Auditing Research. Professor Zehms also acknowledges the financial support from her EY Professorship, along with support from the University of Wisconsin School of Business Andersen Center for Financial Reporting and the University of New South Wales. We gratefully acknowledge the comments provided by workshop participants at the University of Antwerp and PhD students at the University of Wisconsin-Madison. We also appreciate feedback from Wei Chen, Christine Nolder, Diane Mayorga, Sarka Stepankova, and Emily Griffith. 


\subsection{INTRODUCTION}

Auditors' professional skepticism is critical to applying auditing standards and achieving audit quality (e.g., AFM 2014; PCAOB 2015b; IFIAR 2015; IAASB 2015, 2017), and a global recurring theme in audit inspection findings is that auditors struggle to appropriately apply skepticism in their judgments and decision making (PCAOB 2012; IAASB 2015; IFIAR 2015). Prior research provides measures of skepticism with respect to moral courage (Sekerka et al. 2009), interpersonal trust (Rotter 1967; Wrightsman 1991) and auditor-specific trait skepticism (Hurtt 2010). Other research yields theoretical models of auditor professional skepticism, positing factors that contribute to skeptical intentions and skeptical actions (Nelson 2009; Hurtt et al. 2013; Nolder and Kadous 2018). The purpose of our study is to provide an empirical test of these measures and theories, examining individual differences and personality traits that affect traitbased professional skepticism, testing the associations between factors related to behavioral intentions toward skepticism, and revealing their collective association with skeptical actions with respect to evidence collection and evaluation.

We integrate prior theories of auditor professional skepticism and the Theory of Planned Behavior (Ajzen 1991) to develop the conceptual model for this study, which we then use to inform our empirical analyses. Phase I of the model considers a host of individual differences (gender, experience, and knowledge) and personality traits ('Big 5' and Dark Triad indicators of personality) that may affect auditors' professional skepticism traits. The model acknowledges a variety of perspectives on skepticism, including neutral (assuming neither honesty or dishonesty on the part of management; see e.g., PCAOB AS 1015 para. .09), presumptive doubt (recognizing the possibility of management bias despite prior honesty and integrity; see e.g., ISA 240.24), and the moral courage to take skeptical actions (see e.g., ISA 200, A21). Phase II advances the Theory of Planned Behavior (Ajzen 1991; Ajzen 2005; Ajzen 2012) in the context of auditor professional skepticism, thereby extending prior accounting research that employs that theory to study topics such as financial reporting fraud, tax compliance, career choices, and auditors' use of support systems (Bobek and Hatfield 2003; Buchan 2005; Carpenter and Reimers 2005; Dowling 2009; Bagley, Dalton, and Ortegren 2012; Dalton, Bucheit, and McMillan 2014). We hypothesize that skepticism traits are positively associated with attitudes about behaving skeptically, subjective norms (i.e., social pressure to behave skeptically), and perceived behavioral control over obstacles to behaving skeptically. The conceptual model then provides insights as to our expectations that these factors are each positively associated with both skeptical intentions and skeptical actions. In Phase III, the model acknowledges the importance of situational characteristics with respect to anticipating auditors' skeptical actions and enables us to 
hypothesize that auditors' skeptical intentions are positively associated with skeptical actions with respect to searching for evidence, questioning its veracity, and suspending judgment until evidence search and analysis concludes.

To conduct the study, we obtained our data via the Foundation for Auditing Research (FAR), which provided anonymized and transformed responses from six audit firms in the Netherlands, including two Big 4 and four non-Big 4 firms and 663 auditors across all ranks from staff through partner. Participants completed an experiential questionnaire (e.g., see Gibbins and Trotman 2002) about one of their actual audit engagements. We employ three measures of skepticism: the Hurtt Professional Skepticism scale (HPS; Hurtt 2010, which adopts a neutral perspective), the Professional Moral Courage scale (PMC; Sekerka et al. 2009), and Rotter's Interpersonal Trust scale (RIT; Rotter 1967; Wrightsman 1991, which adopts a presumptive doubt perspective). We measure individual differences including gender, age/audit experience, and audit knowledge. We measure personality traits with respect to the 'Big 5' personality characteristics (i.e., extraversion, agreeableness, conscientiousness, emotional stability, and openness) and with respect to the Dark Triad (i.e., Machiavellianism, narcissism, and psychopathy) using validated measures (Jones and Paulhus 2014; Gosling, Rentfrow, and Swann 2003). Measures relating to the Theory of Planned Behavior include attitudes, subjective norms (social expectations around skepticism), perceived behavioral control (auditors' perceptions about the relative difficulty they will experience in executing skepticism), and intentions toward acting skeptically. We control for Big 4 audit firm membership, the ethical tone at the top of each audit firm, client importance, and budget pressure to represent audit firm-level antecedents to skeptical actions. We measure skeptical actions with respect to searching for evidence, questioning the veracity of evidence, and suspending judgment to consider evidence before reaching a decision on one of their actual audit engagements from practice.

Our results reveal that higher-ranked auditors have greater neutral trait skepticism than lowerranked auditors and partners' scores with respect to professional moral courage to take action are significantly higher than all other ranks. In contrast, we find that partners and managers have more interpersonal trust than lower-ranked auditors, possibly because auditors with lower trust are most likely to leave the profession entirely (Cohen, Dalton, and Harp 2017). With respect to individual differences, female auditors have lower skepticism traits, while more knowledgeable auditors have higher skepticism traits. Regarding personality, we find that more-skeptical auditors tend to be conscientious, open to new experiences, and express greater narcissism. They are also less agreeable, and less psychopathic than less-skeptical auditors. Hypothesis-testing results are consistent with the Theory of Planned Behavior, whereby professional skepticism traits 
are positively associated with attitudes toward behaving skeptically, subjective norms about skepticism, perceived behavioral control, and intentions toward acting skeptically. Importantly, these intentions are positively associated with auditors' subsequent search for information, questioning of evidence, and suspending judgment while making audit judgments and decisions in the field.

Our study yields several notable incremental contributions to prior literature. First, we provide large-scale evidence on the antecedents to auditors' professional skepticism using validated scales, revealing the importance task-specific knowledge. Second, audit firms use personality tests during personnel screening (e.g., KMPG 2020) and our results speak to the importance of finding the right personality fit for the profession with regard to ultimately attracting and retaining professionals that are able to take skeptical actions as the standards and regulators require. Further, because our results reveal specific associations between three alternative measures of trait professional skepticism - with respect to neutral, presumptive doubt, and moral courage and a host of personality traits, users of our research can map the type of skepticism that a task requires with the type of personality trait necessary to accomplish a particular auditing objective. Our results are also notable because they report on data that is particularly difficult to obtain psychometric details including sensitive personal information across all ranks in audit firms.

Our third incremental contribution lies in providing an empirical test of a conceptual model of auditor professional skepticism, which builds on existing conceptual models (Nelson 2009; Hurtt et al. 2013; Nolder and Kadous 2018) and the Theory of Planned Behavior. These conceptual models on auditor professional skepticism developed in prior literature have been important in motivating research on skepticism and its relationship with audit quality (Knechel et al. 2013), as well as guiding a path towards ultimate empirical tests - ours is the first study to provide largescale empirical evidence on many aspects that these models articulate as important. The results from our large sample size across a range of auditor ranks and audit firms provide assurance regarding the external validity and generalizability of the associations that we observe. Further, no prior research in auditing provides an empirical test of The Theory of Planned Behavior with respect to the critical role that attitudes, perceived behavioral control, and subjective norms play in skeptical intentions and skeptical actions. We find that subjective norms are the most important driver of auditors' intentions to ultimately act with skepticism. Thus, we provide a specific avenue (i.e., social pressure) by which interventions can focus to encourage organizational change regarding enhancing professional skepticism.

Finally, our study provides a holistic understanding of professional skepticism by simultaneously incorporating antecedents of various professional skepticism traits, factors that 
affect the association between trait skepticism and skeptical intentions, and of the relationship between skeptical intentions and skeptical actions. This approach allows us to examine relative effect sizes of given associations (e.g., the association between subjective norms and intentions to behave skeptically), while controlling for other relevant factors (e.g., the association between attitudes and intentions to behave skeptically). In contrast, prior empirical research on professional skepticism often focuses on singular relations in isolation such as between trait skepticism and auditors' reliance on management explanations (Quadackers et al. 2014), effects of partner communication on auditors' skepticism (e.g., Harding and Trotman 2017), or supervisors' evaluations of skeptical behavior (Brazel, Jackson, Schaefer, and Stewart 2016).

\subsection{LITERATURE REVIEW AND HYPOTHESES}

\section{Models of Professional Skepticism in Auditing}

Auditing standards emphasize the importance of professional skepticism (IAASB 2012; PCAOB 2003, 2006) and note its role in the collection and critical evaluation of evidence (IAASB 2016, ISA 240). ${ }^{10}$ Regulators provide many examples of deficiencies in skepticism leading to audit quality detriments (e.g., IFIAR 2015; PCAOB 2019a), and researchers offer a number of conceptual models with respect to auditor professional skepticism.

Nelson's (2009) model describes how auditors apply knowledge, leverage personal traits, and respond to incentives with respect to audit-evidence judgments. Auditor knowledge can have both positive and negative effects on skepticism, whereby it may enable auditors to correctly recognize evidence patterns, but it may also lead auditors to default to (common) non-error explanations even in the presence of a misstatement. Individual personality traits may predispose auditors toward adopting a neutral view of skepticism - one in which the auditor seeks to verify management assertions without any directional bias (i.e., 'trust but verify') - or may predispose auditors toward adopting a presumptive doubt view - one in which the auditor assumes that management has a predisposition to bias financial statement assertions (Cohen et al. 2017). In addition to knowledge and personality traits, situational characteristics yield incentives for auditors

10 The PCAOB AS 1015 provides guidance on professional skepticism. "Professional skepticism is an attitude that includes a questioning mind and a critical assessment of audit evidence. The auditor uses the knowledge, skill, and ability called for by the profession of public accounting to diligently perform, in good faith and with integrity, the gathering and objective evaluation of evidence (paragraph .07) ... Since evidence is gathered and evaluated throughout the audit, professional skepticism should be exercised throughout the audit process (paragraph .08) ... The auditor neither assumes that management is dishonest nor assumes unquestioned honesty. In exercising professional skepticism, the auditor should not be satisfied with less than persuasive evidence because of a belief that management is honest" (paragraph .09). 
to adopt varying levels of skepticism. For example, a complex, risky client may trigger a more skeptical mindset, whereas budget pressure may trigger a less skeptical mindset. Within this context, Nelson's (2009) model adopts a presumptive doubt perspective and anticipates that evidential input will integrate with skeptical judgments and actions to yield high-quality evidential outcomes. ${ }^{11}$

The Hurtt (2010) model focuses on skepticism as an individual auditor trait, anticipating that state skepticism (which derives from situational characteristics) mediates the association between trait skepticism and skeptical behavior. Nolder and Kadous' (2018) model adopts a similar perspective, whereby auditors' skepticism incorporates both a skeptical attitude and a skeptical mindset whereby auditors integrate evidential input via cognitive processing in targeting their skeptical judgments and intentions toward skeptical actions. Their model also acknowledges the importance of social/situational determinants with respect to auditor skepticism.

Figure 2.1 depicts our own conceptual model, which extends the collective whole of these models. Phase I considers a host of characteristics that may affect auditors' professional skepticism traits, including individual differences (age, gender, experience, and knowledge) and personality traits ('Big 5' and Dark Triad personality characteristics). We conceptualize various perspectives on skepticism, including neutral, presumptive doubt, and the moral courage to act, each of which the professional standards recognize as necessary in varying decision settings. For example, professional quality control standards take a neutral perspective whereby "the auditor neither assumes that management is dishonest nor assumes unquestioned honesty ... the auditor should not be satisfied with less than persuasive evidence because of a belief that management is honest" (PCAOB AS 1015 para .09). In contrast, auditing standards relating to the consideration of fraud take the presumptive doubt perspective and acknowledge potential management bias by "recognizing the possibility that a material misstatement due to fraud could exist, notwithstanding the auditor's past experience of the honesty and integrity of the entity's management" (ISA 240.24). From this perspective, skepticism is the opposite of trust (Shaub 1996) and auditors present varying levels of dispositional trust or distrust (McKnight, Choudhury, and Kacmar 2002; McKnight, Kacmar, and Choudhurry 2004; Harding, Azim, Jidin, and Muir 2016). The moral courage perspective focuses on auditors' willingness to take skeptical actions (Hurtt et al. 2013), and auditing standards also reflect this perspective. For example, ISA 200 states that "in cases of doubt about the reliability of information or indications of possible fraud ...

11 Hurtt, Brown-Liburd, Earley, and Krishnamoorthy (2013) directly extend Nelson's (2009) model, providing important insights regarding the antecedents of skepticism including auditor, evidential, client, and external environment characteristics. 
the ISAs require that the auditor investigate further and determine what modifications or additions to audit procedures are necessary to resolve the matter" (ISA 200, A21). Phase II advances the Theory of Planned Behavior (Ajzen 1991; Ajzen 2005; Ajzen 2012) in the context of auditor professional skepticism. Here we posit that variation in auditors' professional skepticism traits is positively associated with attitudes about behaving skeptically (Nolder, Kadous, and Peecher 2019; Nolder and Blankenship 2019), subjective norms with respect to the social pressure to behave skeptically (Peecher 1996), and perceived behavioral control over behaving skeptically (Hasson and Knechel 2019). We argue that each of these factors is positively associated with intentions to act skeptically. In Phase III, we anticipate that auditors' skeptical intentions will positively mediate the associations between attitudes, subjective norms, and perceived behavioral control and skeptical actions with respect to searching for evidence, questioning its veracity, and suspending judgment until evidence search and analysis concludes. Further, we acknowledge the role that situational characteristics may play in affecting skeptical actions.

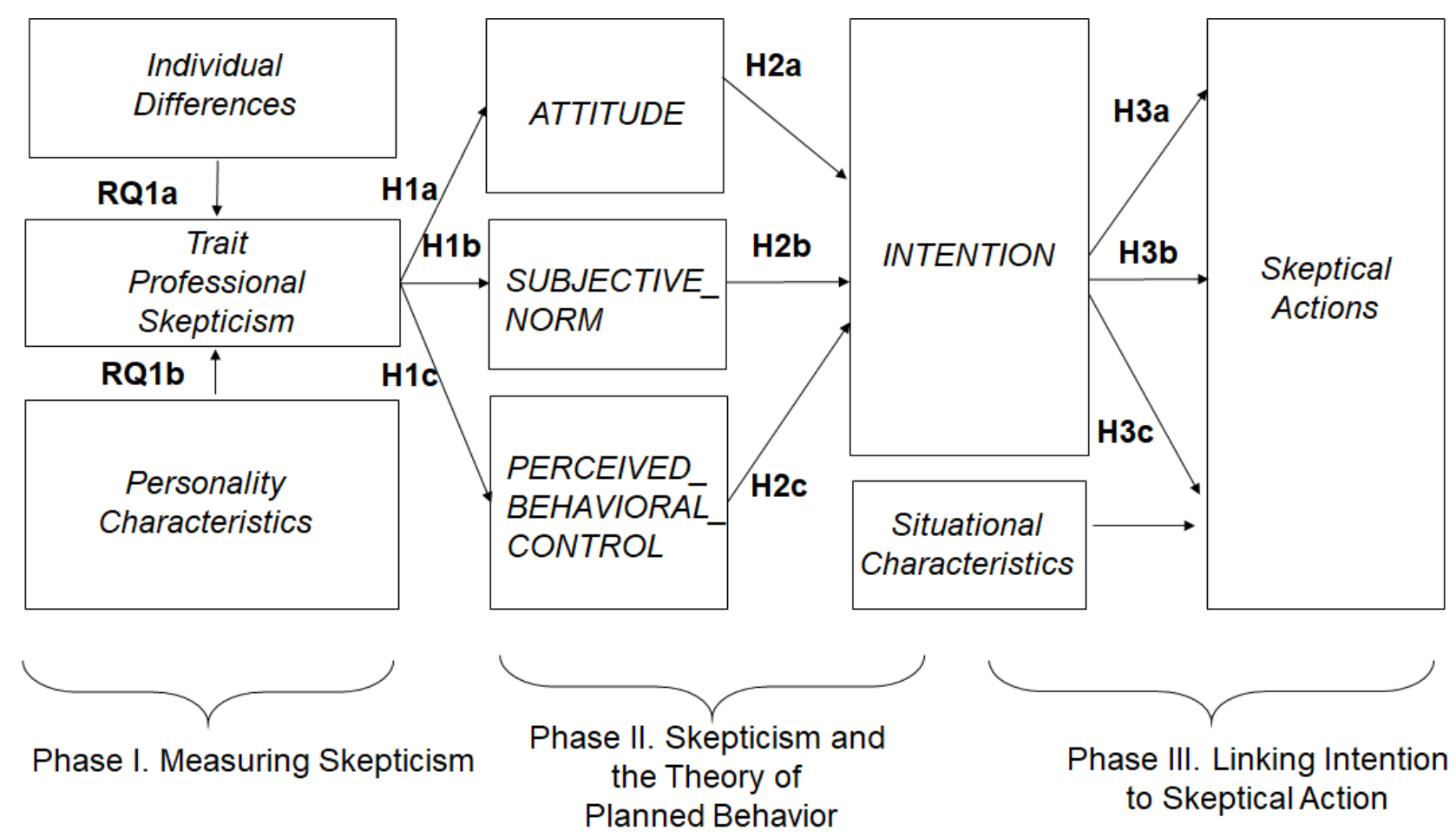

Figure 2.1 Conceptual model and hypotheses 


\section{Individual Differences, Personality Characteristics, and Professional Skepticism}

Individual differences exist that are associated with auditors' professional skepticism traits albeit with mixed directional inferences - including age, experience, gender and task-specific knowledge. In experimental settings, Payne and Ramsay (2005) report a decline in skepticism as auditors age and gain more experience. Similarly, Shaub and Lawrence (1999) find that staff are significantly more skeptical than higher-ranked auditors. Alternatively, older partners might accumulate portfolios of higher-quality clients (Lennox and Wu 2018), for which professional skepticism is less critical and therefore less salient. In contrast, Knapp and Knapp (2001) report that audit managers are more skeptical than seniors in assessing fraud risk. Archival research similarly presents mixed evidence. For example, both Goodwin and Wu (2016) and Sundgren and Svanström (2014) document a negative association between partner age and audit quality, while Chi, Myers, Omer and Xie (2017) document a positive association between a partner's years of prior experience (as a partner) at the start of the current engagement and audit quality. The association between gender and professional skepticism is unclear as well (Olsen and Gold 2018), although neuroscience research reveals that gender plays a role in processing emotions whereby negative emotions are more salient for women (Drobyshevsky, Baumann, and Schneider 2006; Koch, Pauly, Kellermann, Seiferth, Reske, Backes, and Habel 2007).

While Nelson (2009) posits that auditor knowledge can have either positive and negative effects on skepticism, we expect that task-specific knowledge is positively associated with skepticism. An auditor who has previously encountered fraud or who has assessed subjective management valuations will be more skeptical than auditors without such experiences because they are familiar with methods by which management accomplishes manipulations. This line of reasoning is consistent with research documenting that task-specific knowledge improves audit quality (Bonner 1990; Goldman, Harris, and Omer 2019).

Personality characteristics may also play a role in trait skepticism (Khan and Harding 2020). The 'Big 5' personality characteristics include extraversion, conscientiousness, emotional stability, openness, and agreeableness (McCrae and Costa 1990). Extraversion represents the degree to which an individual is enthusiastic and empathetic as opposed to being reserved and quiet around others (Scott, Colquitt, Paddock, and Judge 2010). Conscientiousness concerns relative self-discipline (Judge and Ilies 2002). Emotional stability, or its opposite - neuroticism represents the degree to which an individual is calm as opposed to anxious or easily upset (Eysenck 1991). Openness concerns a relative willingness to engage in new or potentially risky experiences (Mervielde, De Fruyt, and Jarmuz 1998). Agreeableness reflects the extent to which an individual is sympathetic as opposed to being critical (Costa and McCrae 1992). In a study 
employing undergraduate accounting students with minimal experience in public accounting and the Hurtt (2010) measure of professional skepticism, Farag and Elias (2016) report a positive association between each of the Big 5 personality characteristics and trait skepticism. Therefore, we anticipate a positive association between skepticism and extraversion, conscientiousness, emotional stability, and openness. However, we anticipate a negative association between skepticism and agreeableness because it seems logical that less-agreeable auditors are more likely to challenge management assertions.

The Dark Triad personality characteristics may also play a role in trait skepticism. Machiavellianism, narcissism, and psychopathy share a common theme with respect to socially unattractive traits and a lack of appropriate empathy and emotionality in interactions with others (Paulhus and Williams 2002; Book, Biser, and Volk 2015). Recent work by Hobson, Stern, and Zimbelman (2019) finds that auditors with high levels of Dark Triad personality characteristics are distrustful (i.e., avoid unjustified trust) even in the presence of social interactions with client managers. Further, Church, Dai, Kuang, and Liu (2019) suggest that more-narcissistic auditors encourage higher financial reporting quality, and are also tougher negotiators, thereby achieving more-conservative negotiated outcomes. At the same time, other research shows that Dark Triad personality characteristics are associated with unethical attitudes and counterproductive workplace behaviors (Bailey 2015; Harrison, Summers, and Mennecke 2018; O'Boyle, Forsyth, Banks, and McDaniel 2012). Further, more-psychopathic individuals tend to do whatever is necessary to achieve their goals, and are more likely to engage in or accept unethical behavior through the process of moral disengagement (Stevens, Deuling, and Armenakis 2012). Hence, individuals with greater psychopathy may be less skeptical. Based on this discussion, we anticipate a positive association between trait skepticism and both Machiavellianism and narcissism, but a negative association with psychopathy. Our conceptual model begins by investigating how individual differences and personality characteristics affect professional skepticism traits:

RQ1: How are (a) individual differences and (b) personality characteristics associated with professional skepticism traits?

\section{Professional Skepticism and The Theory of Planned Behavior}

The second phase in our conceptual model employs the Theory of Planned Behavior (Ajzen 1991; Ajzen 2012), which researchers use to predict, explain, and change human behavior. Nolder and Kadous (2018, p. 4) suggest that the attitude literature can provide insights into the 
relationship between skeptical attitudes and skeptical behavior and call for research that examines this relationship, while noting that "conceptualizing professional skepticism as a mindset and an attitude implies that skepticism is exercised, and thus should be measured, situationally". Our goal is to predict and explain how trait skepticism affects attitudes toward, intentions about, and ultimately auditors' skeptical actions with respect to evidence collection and evaluation.

The Theory of Planned Behavior proposes, and our conceptual model is consistent with, the notion that intentions about performing a behavior mediate the direct association between attitudes, subjective norms, and perceived behavioral control with respect to behavioral actions. ${ }^{12}$ Attitude "refers to the degree to which a person has a favorable or unfavorable evaluation or appraisal of the behavior in question" and subjective norm "refers to the perceived social pressure to perform or not to perform the behavior" (Ajzen 1991, p. 188). Perceived behavioral control "refers to people's perception of the ease or difficulty of performing the behavior of interest" (Ajzen 1991, p. 183) and is closely linked to perceived self-efficacy, i.e., "judgments of how well one can execute courses of action required to deal with prospective situations" (Bandura 1977, $1982 \mathrm{p}$. 122). A limitation of the Theory of Planned Behavior is that it provides few insights with respect to antecedents of attitude, subjective norms (i.e., social pressures), and perceived behavioral control (e.g., Armitage and Conner 1999, 2001). Therefore, we extend the theory by examining the role of professional skepticism as an antecedent to these drivers of intention, predicting that:

H1: Professional skepticism traits are positively associated with:

(a) attitudes about behaving skeptically

(b) subjective norms with respect to the pressure to behave skeptically, and

(c) perceived behavioral control to behave skeptically.

Attitudes, subjective norms, and perceived behavioral control each predict intentions, which are crucial for securing long-term goals (Ajzen 1991; Kuhl annd Quirin, 2011; Baumeister and Bargh 2014). Intentions are important because they indicate how much effort individuals will exert

\footnotetext{
12 According to Ajzen (1991, p. 189), precursors to attitudes, subjective norms, and perceived behavioral control include "behavioral beliefs, which are assumed to influence attitudes toward the behavior, normative beliefs which constitute the underlying determinants of subjective norms, and control beliefs which provide the basis for perceptions of behavioral control". Fishbein and Ajzen (1975) employ a cognitive/information-processing approach to understanding the behavioral beliefs individuals hold, which they form by linking behaviors to outcomes with respect to positive or negative attitudinal expectations. In this way, individuals learn to form positive attitudes about behaviors with desirable consequences and negative attitudes about behaviors with undesirable consequences. Normative beliefs involve how an individual is motivated by referent groups' relative approval or disapproval regarding a given behavior. Control beliefs relate to factors that enhance or inhibit the relative difficulty of performing a given behavior.
} 
to engage in subsequent decision-relevant actions. Hurtt et al. (2013) cast these factors within the context of the motivation to behave skeptically. The Theory of Planned Behavior anticipates a positive association between: an individual's attitude towards a behavior (Nolder et al. 2019), subjective norms (i.e., social pressure) surrounding the behavior (Peecher 1996), a higher perceived behavioral control (i.e., self-efficacy) with respect to the behavior (Hasson and Knechel 2019) and the intention towards taking action with respect to the behavior (e.g., Gibson and Frakes 1997; Carpenter and Reimers 2005; Heirman, Walrave, Vermeulen, Ponnet, Vandebosch, and Hardies 2016). Nolder and Kadous (2018, p. 9) conceptualize attitudes as "auditors' cognitive and affective evaluative responses associated with management's assertions" and depict perceived behavioral control in the context of auditors' beliefs about their authority to modify audit programs in light of risk assessments. Research in fraud brainstorming shows that leadership behaviors relating to subjective norms can affect subordinates' skeptical orientations (i.e., intentions) and subsequent skeptical actions (Harding and Trotman 2017; Dennis and Johnstone 2018). Other research in auditing shows that when peers share attitudes reflecting a high (low) emphasis on professional skepticism, other auditors are more (less) skeptical in their judgments (Ying, Patel and Pan 2019). Based on this discussion, we expect that:

H2: (a) Attitudes, (b) subjective norms, and (c) perceived behavioral control are positively associated with intentions to behave skeptically.

\section{Skeptical Actions}

Meta-analyses typically indicate a strong positive association between intentions and behavioral actions (e.g., Armitage and Conner 2001; Sheeran 2002; Webb and Sheeran 2006). Likewise, in an auditing context, Fullerton and Durtschi (2004) show that internal auditors with high professional skepticism traits (based on the Hurtt scale) are more likely than low skepticism auditors to expand their search for evidence. Other studies also show a positive association between risk assessments (i.e., an intention to act skeptically) and both modifying audit plans and conducting audit procedures (e.g., Johnstone and Bedard 2001; Graham and Bedard 2003; Hoffman and Zimbelman 2009).

In contrast, other research shows that auditors have difficulty linking fraud risk assessments with fraud risk responses such as tailoring audit plans (e.g., Mock and Turner 2005; Hammersley, Johnstone, and Kadous 2011). Therefore, auditors in some cases fail to follow through with skeptical actions despite properly assessing risk, which implies only an intention to respond according to professional standards (e.g., IAASB 2016, ISA 240). Further, research also shows 
that different types of skepticism, one that adopts a neutral perspective as compared to one that adopts a presumptive doubt perspective, may differentially affect skeptical actions. Quadackers et al. (2014) find that auditors with higher levels of presumptive doubt skepticism who are making decisions in a high-risk setting respond by making more skeptical judgments and decisions compared to auditors with higher levels of neutral skepticism. This implies that individuals with differential skeptical traits may respond differently with respect to their skeptical intentions and subsequent actions. Bowlin et al. (2015) also cast some doubt on the association between skeptical intentions and skeptical actions. They find that auditors who adopt a skeptical frame of mind decrease audit effort upon auditor-client rotation, reducing audit quality. While acknowledging tension with respect to our expectations, we make the following predictions:

H3: Intentions to behave skeptically are positively associated with skeptical actions during the audit in terms of:
(a) searching for audit evidence,
(b) questioning audit evidence, and
(c) suspending judgment about audit evidence.

\subsection{METHODOLOGY}

\section{Sample and Participants}

We obtain our data from Dutch audit firms through the Foundation for Auditing Research (FAR). Representatives of an independent datacenter (CenterData) sent an email invitation (and a maximum of three subsequent follow-up emails) during 2018 to audit firms who had previously agreed to participate in the FAR's research agenda. CenterData anonymized and transformed responses from six audit firms in the Netherlands that chose to participate, including two Big 4 and four non-Big 4 firms. Each firm agreed to provide a specific number of fiscal year-end 2016 engagements in proportion to the total number of audit engagements that they conduct each year. $^{13}$

13 Representatives at each firm used a three-step process to select engagements. First, they randomly selected partners whose engagements were to be the subject of within-firm engagement quality review (this requirement was imposed because the authors are interested in engagement quality review for a different research study). If that process yielded the agreed-upon number of engagements, the selection process concluded. If it did not, the second step included randomly selecting any remaining audit partners within the firm until the agreed-upon number of engagements was achieved. Third, if the sampling process exhausted all partners and the agreed-upon number of engagements was still not achieved, then the representatives randomly selected the sample from all other engagements. 
Table 2.1 shows that this sampling process yielded 342 selected engagements and 1,447 individual auditors. In total, 858 auditors responded (59.3\% response rate), and after eliminating observations with missing data, the final sample size equals 663 auditors. ${ }^{14}$ The percentage (number) of responses by rank is $21 \%$ (139), 26\% (174), 16\% (103), and 37\% (247) for partners, managers, seniors, and staff, respectively. Firm 1 makes up the greatest proportion of the sample $(36.6 \%)$, whereas Firm 6 the smallest $(1.7 \%) .{ }^{15}$

Table 2.1 Sample Composition

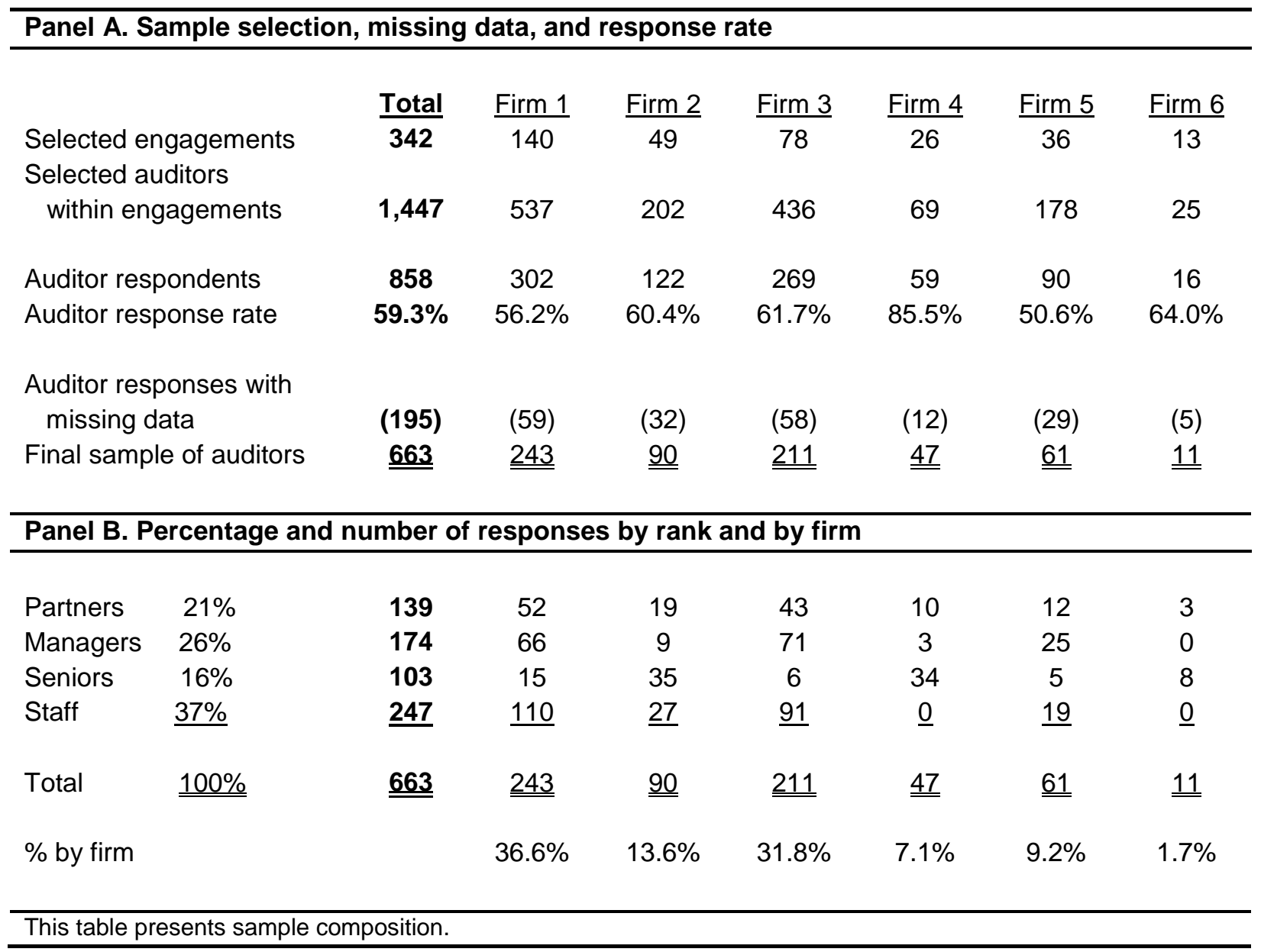

14 Of the 663 auditors in our final sample, 140 were assigned to engagements that would later be subject to engagement quality review. There are no significant differences in terms of professional skepticism traits, attitudes, intentions and actions based on whether an auditor's engagement was or was not selected for engagement quality review. Analyses using responses of auditors working on non-reviewed engagements only $(N=523)$ yield essentially the same results.

15 In untabulated results, about one percent of our sample clients are listed. Sixty-one percent use Dutch GAAP, 11 percent use IFRS, less than one percent use US GAAP, and for the remainder this information is missing. The audit requirements in the Netherlands are derived from the EU Audit Directives. The International Standards on Auditing as issued by the International Auditing and Assurance Standards Board are applicable. 
Participating auditors each responded to our invitation via a survey. The first part includes questions relating to demographics and measures of professional skepticism, which we introduce as follows: "In this first part of the survey, you will have to answer questions about yourself, including how you feel and think about certain aspects of your work life and life in general" (underline appears in original). The next part includes questions relating to the auditors' employer, which we introduce as follows: "In this second part of the survey, you will have to answer questions about perceptions about your accounting firm and your work environment." The third part includes an experiential questionnaire that asks auditors to reflect on one of their actual audit engagements as directed by CenterData personnel and audit firm contacts (i.e., individual auditors were not allowed to self-select an engagement of their choice). We introduce this part as follows: "In the remainder of this survey, you will have to answer questions about the audit engagement of a specific client that you worked on (as explained in the accompanying letter to this survey research). All questions hereafter refer to this specific engagement ...".

The experiential questionnaire asks auditors to make retrospective recalls of information relating to each of the phases in our conceptual model. Retrospective recalls provide evidence about the facts and inferences that individuals believe to be part of the original event (e.g., Ericsson and Simon 1980; Nelson, Eliott, and Tarpley 2002; Hammersley 2006; Dennis and Johnstone 2018). Since retrospective recalls are subject to validity threats, we follow the precepts of the Critical Incident Technique (Flanagan 1954) and the Experimental Questionnaire Method (Gibbins and Qu 2005) to minimize these threats. Furthermore, we promote accuracy by asking auditors to recall specific experiences and by avoiding leading questions (e.g., Christ 1993; Gibbins, Salterio, and Webb 2001; Gibbins and Trotman 2002; Nelson et al. 2002).

\section{Variables}

\section{Professional Skepticism}

We employ three measures of skepticism that accounting researchers use: the Hurtt Professional Skepticism scale (HPS; Hurtt 2010), the Professional Moral Courage scale (PMC; Sekerka et al. 2009), and Rotter's Interpersonal Trust scale (RIT; Rotter 1967; Wrightsman 1991). HPS adopts a neutral perspective and includes 30 questions that collectively assess auditors' behaviors with respect to having a questioning mind, being willing to suspend judgment, searching for knowledge, possessing interpersonal understanding, and having autonomy and self-esteem. Each question includes a six-point Likert response scale that ranges from strongly disagree to strongly agree, with higher scores indicating greater neutral trait skepticism. PMC includes 15 questions about work-related ethical issues indicating a behavioral perspective consistent with 
the desire and ability to act. Each question includes a five-point Likert scale that ranges from almost never true to almost always true, with higher scores indicating a greater willingness to take skeptical actions. RIT includes 25 questions that capture an expectancy that another individual or group can be relied upon from a presumptive doubt perspective. Each question includes a fivepoint Likert response scale that ranges from strongly disagree to strongly agree, whereby higher scores indicate greater interpersonal trust; we reverse-scored the questions such that higher scores indicate greater presumptive doubt trait skepticism (RIT). See Appendices I and IV for individual questions and accompanying measurement scales relating to all variables.

\section{Individual Differences and Personality Traits}

We measure individual differences including $A G E$ (in years), GENDER (= 1 if female; $=0$ if male), EXPERIENCE_YRS, and self-assessed AUDIT_KNOWLEDGE (on a scale from $=1$ if not at all experienced to $=7$ if extremely experienced) for tasks relating to valuation (KNOW_VALUATION; level of experience with difficult accounting measurement and valuation problems), fraud (KNOW_FRAUD; level of experience assessing risks of material misstatements due to fraud), and analytical procedures (KNOW_ANALYTICAL_PROC; level of experience applying analytical procedures during an audit). We measure personality traits in terms of the Big 5 personality characteristics: EXTRAVERSION (the degree of enthusiasm with being around others as opposed to being reserved and quiet around others), AGREEABLENESS (the degree of criticality as opposed to sympathy towards others), CONSCIENTIOUSNESS (the degree of dependability and self-discipline as opposed to disorganization or carelessness), EMOTIONAL_STABILITY (the degree of anxiousness as opposed to calm), and OPENNESS (the degree to which an individual is open to new experiences as opposed to preferring conventional routines) using the Ten Item Personality Inventory (Gosling et al. 2003 on a scale from = 1 disagree strongly to $=7$ agree strongly). We also measure personality in terms of the Dark Triad: MACHIAVELLIANISM (the extent of subtle or unscrupulous deception or expediency in decision making), NARCISSISM (the extent of self-absorption or arrogance in decision making), and PSYCHOPATHY (the extent of amoral or antisocial behavior) using the Short Dark Triad scale (Jones and Paulhus 2014 on a scale from $=1$ disagree strongly to $=5$ strongly agree).

\section{Attitudes and Intentions}

Consistent with prior research (e.g., Buchan 2005; Dowling 2009; see Fishbein and Ajzen 2010), we use direct measures of attitude, subjective norms, perceived behavioral control, and 
intentions. ${ }^{16}$ We measure each auditor's ATTITUDE toward professional skepticism based on five relative indicators: good/bad, harmful/beneficial, pleasant/unpleasant, difficult/easy, and unimportant/important, whereby a higher score indicates a more-positive attitude. We measure subjective norms $(S M)$ based on three relative indicators about social expectations around skepticism (their own feelings of social pressure, others' feelings of social pressure, and the firm's social pressure to maintain skepticism), whereby a higher score indicates that an auditor perceives greater social pressure to engage in skeptical behavior. We measure perceived behavioral control $(P B C)$ based on three relative indicators about the extent to which an auditor believes they have the self-control to maintain skepticism during the audit (whether maintaining skepticism is up to the auditor, whether the auditor believes that maintaining skepticism is beyond their control, and their confidence in maintaining skepticism), whereby a higher score indicates that an auditor has higher self-efficacy in maintaining skepticism. The Theory of Planned Behavior proposes that these three factors drive intention (i.e., the likelihood that an individual plans to engage in a behavior). ${ }^{17}$ We measure INTENTION based on relative agreement with the following statement 'I intend to maintain professional skepticism throughout my next audits', whereby a higher score indicates a stronger intention to take skeptical action.

\section{Situational Control Variables}

Each of the conceptual auditor-skepticism models presents skepticism as situational (Nelson 2009; Hurtt 2010; Nolder and Kadous 2018), suggesting possible mediating or moderating roles for situational variables; for simplicity, we model these variables as controls with main effects on skeptical actions. ${ }^{18}$ Regarding the audit firm, as opposed to the individual auditor, Nolder and Kadous (2018, p. 4) posit that the 'fact that auditors' beliefs and feelings about risk are, at least in part, fostered within the firms, and not innate, implies that firms have some control over auditors' skepticism". We therefore control for the type of audit firm, whereby BIG_4=1 if the auditor's firm is one of the four largest; $=0$ otherwise, anticipating a positive association with skeptical actions. The tone that top management at the audit firm sets is also likely important for how auditors within the firm act with respect to skepticism. Johnstone, Sutton, and Warfield (2001) propose a continuum of audit firm culture, which ranges from a public duty culture (whereby the firm

16 According to the Theory of Planned Behavior, attitudes, social norms, and perceived behavioral control are themselves determined by readily accessible beliefs (i.e., behavioral beliefs, normative beliefs, and control beliefs, respectively) (Ajzen 1991; Ajzen 2005; Ajzen 2012; Fishbein and Ajzen 2010). Assessing these beliefs is outside the scope of our study.

17 For the variables HPS, PMC, RIT, ATTITUDE, and SUBJECTIVE_NORM Cronbach alpha scores are at or above 0.60, which indicates an acceptable composite reliability (Tabachnick and Fidell, 2013); Cronbach's alpha for PERCEIVED_BEHAVIORAL_CONTROL equals 0.34. See Appendix IV for specific values.

18 We obtain similar results when modeling situational variables as mediators or moderators. 
encourages its auditors to consider the needs of investors and creditors by adhering to the professional ethics standards) to a client advocacy culture (whereby the firm encourages its auditors to 'add value' to clients by viewing themselves as business partners with client management and thereby moving away from professional ethics standards). ${ }^{19}$ We measure audit firm culture via TONE_AT_TOP, which consists of four variables about firm expectations around ethical behavior to which auditors rate their level of agreement (e.g., behavior of leadership and tolerance for unethical acts), whereby a higher score indicates that an auditor perceives that the firm encourages a more ethical tone at the top (Sweeney, Arnold, and Pierce 2010). We expect a positive association between TONE_AT_TOP and skeptical actions. We also measure CLIENT_IMPORTANCE to proxy for the extent of resources that the firm allocates to the engagement (e.g., based on client size and complexity). We measure this variable as the number of engagement team members, and expect a positive association between CLIENT_IMPORTANCE and skeptical actions. As a complement to client importance, we also control for the possibility for quality-reducing actions that result from budget pressure (e.g., Kelley and Margheim 1990; Ponemon 1992; Glover 1997; Bedard, Ettredge, and Johnstone 2008; Ettredge, Bedard, and Johnstone 2008). We measure BUDGET_PRESSURE using variables relating to pressure, attainability, and ability to complete work within the allocated time; higher scores indicate greater perceived pressure. We expect a negative association between BUDGET_PRESSURE and skeptical actions.

\section{Skeptical Actions}

The ultimate judgment and decision-making behavior that auditors need to accomplish involves taking skeptical actions. International Auditing Standard 200 illustrates the need for auditors to take skeptical actions with respect to obtaining and evaluating audit evidence:

Professional skepticism is necessary to the critical assessment of audit evidence. This includes questioning contradictory audit evidence and the reliability of documents and responses to inquiries and other information obtained from management and those charged with governance. It also includes consideration of the sufficiency and appropriateness of audit evidence. (para. A20)

19 We note that recent work by Knechel, Thomas and Driskill (2020) conceptualizes financial statement auditing as an economic service where cooperation between the audit firm and the client is essential for improving audit quality. 
Evaluating whether sufficient appropriate audit evidence has been obtained, and whether more needs to be done to achieve the objectives of the ISAs and thereby, the overall objectives of the auditor. (para A23)

We measure skeptical actions using three constructs from the scales in Robinson et al. (2018) and with respect to a specific audit engagement: SEARCHING_FOR_EVIDENCE (e.g., actively seeking information and using available resources), QUESTIONING (e.g., rejecting statements unless there exists relevant proof), and SUSPENDING_JDGMT (taking time to make decisions and considering available information before reaching a decision). Higher scores indicate that the auditor acted with higher skepticism during the engagement. We estimate each phase of our conceptual model (see Figure 1) and the accompanying measurement model jointly and simultaneously via structural equation modeling using STATA's SEM.

\subsection{RESULTS}

\section{Measurement model}

The results of the CFA are reported in Appendix IV. The measurement model provides a good fit for the data. The variables attitude, perceived behavioral control, subjective norm, and skeptical actions are treated as latent constructs and the other variables are all treated as observed variables. All factor loadings are significant and, except for perceived behavioral control, the Cronbach alpha's are at or above .60 indicating an acceptable composite reliability (Tabachnick and Fidell 2013). ${ }^{20}$

\section{Descriptive Statistics: Skepticism}

Table 2.2 reports descriptive statistics on trait skepticism (Panel A), descriptive statistics on skepticism by rank (Panel B), and differences in skepticism by rank (Panel C). The mean HPS equals 137.29 based on a theoretical range of 30-180. HPS for staff, seniors, managers, and partners is about $135,136,138$, and 141 , respectively. Partners' scores are significantly higher than all other ranks, and managers' scores are significantly higher than staff. Thus, higher-ranked auditors have greater neutral trait skepticism than lower-ranked auditors. The mean $P M C$ equals 79.22 based on a theoretical range of 15-105. PMC for staff, seniors, managers, and partners is about 76, 78, 81, and 84, respectively. Partners' $P M C$ scores are significantly higher than all other

20 We also do analyses where we only take into account the observed underlying items with a factor loading above .45 and the results are similar. 
ranks and managers' $P M C$ scores are significantly higher than seniors' and staff. Thus, higherranked auditors have greater moral courage to take skeptical action than lower-ranked auditors.

Table 2.2 Descriptive Statistics for Skepticism Measures

\begin{tabular}{ccccccc}
\hline \multicolumn{7}{l}{ Panel A. Descriptive Statistics for Skepticism Measures } \\
\hline Measure & Mean & Median & $\begin{array}{c}\text { Standard } \\
\text { deviation }\end{array}$ & $\begin{array}{c}\text { Theoretical } \\
\text { range }\end{array}$ & $\begin{array}{c}\text { Actual } \\
\text { range }\end{array}$ & $\begin{array}{c}\text { Cronbach's } \\
\text { alpha }\end{array}$ \\
HPS & 137.29 & 137.59 & 10.60 & $30-180$ & $103-168$ & 0.84 \\
PMC & 79.22 & 79.00 & 10.61 & $15-105$ & $52-105$ & 0.91 \\
RIT & 78.04 & 77.00 & 8.49 & $25-125$ & $54-107$ & 0.76 \\
\hline
\end{tabular}

\begin{tabular}{|c|c|c|c|c|c|c|c|c|c|c|}
\hline \multicolumn{11}{|c|}{ Panel B. Descriptive Statistics by Rank } \\
\hline \multirow[t]{2}{*}{$\underline{\text { Rank }}$} & \multirow[t]{2}{*}{$\underline{N}$} & \multicolumn{3}{|c|}{$\begin{array}{l}\text { Measurement } \\
\text { Scale }\end{array}$} & Mean & \multicolumn{2}{|c|}{$\underline{\text { Std. Dev. }}$} & \multicolumn{2}{|l|}{$\underline{\text { Min }}$} & $\underline{\operatorname{Max}}$ \\
\hline & & \multicolumn{3}{|c|}{ HPS } & 140.93 & & 8.98 & 119 & & 165 \\
\hline \multirow[t]{3}{*}{ Partner } & \multirow[t]{2}{*}{139} & \multicolumn{3}{|c|}{$P M C$} & 84.01 & & 9.96 & 60 & & 105 \\
\hline & & \multicolumn{3}{|c|}{$R I T$} & 75.15 & & 8.77 & 54 & & 105 \\
\hline & \multirow{3}{*}{174} & \multicolumn{3}{|c|}{ HPS } & 138.11 & & 10.47 & 106 & & 168 \\
\hline \multirow[t]{3}{*}{ Manager } & & \multirow{2}{*}{\multicolumn{3}{|c|}{$\begin{array}{c}P M C \\
R I T\end{array}$}} & 81.00 & & 9.48 & 59 & & 105 \\
\hline & & & & & 78.13 & & 8.82 & 57 & & 98 \\
\hline & \multirow{3}{*}{103} & \multicolumn{3}{|c|}{ HPS } & 136.46 & & 9.91 & 110 & & 159 \\
\hline \multirow[t]{2}{*}{ Senior } & & \multirow{2}{*}{\multicolumn{3}{|c|}{$\begin{array}{c}P M C \\
R I T\end{array}$}} & 77.80 & & 9.84 & 54 & & 105 \\
\hline & & & & & 79.97 & & 7.95 & 59 & & 107 \\
\hline \multirow{4}{*}{ Staff } & \multirow{3}{*}{247} & \multicolumn{3}{|c|}{ HPS } & 135.00 & & 11.22 & 103 & & 161 \\
\hline & & \multirow{2}{*}{\multicolumn{3}{|c|}{$\begin{array}{c}P M C \\
R I T\end{array}$}} & 75.87 & & 10.80 & 52 & & 105 \\
\hline & & & & & 78.79 & & 7.96 & 56 & & 107 \\
\hline & \multicolumn{10}{|l|}{$\underline{663}$} \\
\hline \multicolumn{11}{|c|}{ Panel C. Differences in professional skepticism measures by rank } \\
\hline & & \multicolumn{3}{|c|}{ HPS } & \multicolumn{3}{|c|}{$P M C$} & \multicolumn{3}{|c|}{$R I T$} \\
\hline \multicolumn{2}{|c|}{$\underline{\text { Rank (1) vs rank (2) }}$} & $\underline{\Delta}$ & $\underline{\mathrm{t}}$ & $\underline{\mathrm{p}}$ & $\underline{\Delta}$ & $\underline{t}$ & $\underline{\mathrm{p}}$ & $\underline{\Delta}$ & $\underline{t}$ & $\underline{\mathrm{p}}$ \\
\hline \multirow{3}{*}{\multicolumn{2}{|c|}{$\begin{array}{l}\text { Partner vs Manager } \\
\text { Partner vs Senior } \\
\text { Partner vs Staff }\end{array}$}} & 2.82 & 2.5 & 0.012 & 3.01 & 2.7 & 0.007 & -2.98 & -3.0 & 0.003 \\
\hline & & 4.47 & 3.7 & 0.000 & 6.21 & 4.8 & 0.000 & -4.82 & -4.4 & 0.000 \\
\hline & & 5.93 & 5.3 & 0.000 & 8.14 & 7.3 & 0.000 & -3.64 & -4.2 & 0.000 \\
\hline \multirow{2}{*}{\multicolumn{2}{|c|}{$\begin{array}{l}\text { Manager vs Senior } \\
\text { Manager vs Staff }\end{array}$}} & 1.65 & 1.3 & 0.198 & 3.20 & 2.7 & 0.008 & -1.84 & -1.7 & 0.083 \\
\hline & & 3.11 & 2.9 & 0.004 & 5.13 & 5.0 & 0.000 & -0.66 & -0.8 & 0.423 \\
\hline \multicolumn{2}{|c|}{ Senior vs Staff } & 1.46 & 1.1 & 0.253 & 1.93 & 1.6 & 0.119 & 1.18 & 1.3 & 0.207 \\
\hline
\end{tabular}


The mean RIT equals 78.04 based on a theoretical range of 25-125. RIT for staff, seniors, managers, and partners is about $79,80,78$, and 75, respectively. Partners' RIT scores are significantly lower than all other ranks and managers' scores are marginally lower than seniors' scores. The results for partners and managers imply that these auditors have greater interpersonal trust than seniors or staff, which is in contrast to the inferences for the HPS and the PMC scales. A potential explanation lies in the results of Cohen et al. (2017), who report that auditors with lower trust are more likely to leave the profession, resulting in auditors with higher trust rising through the ranks toward manager and partner status.

\section{Descriptive Statistics: Individual Differences, Personality Traits, Attitudes, and Actions}

Table 2.3 Panel A includes descriptive statistics for all variables in our conceptual model, and Panel B includes comparisons by high-versus-low skepticism, dichotomized at the median of each skepticism measure. Mean AGE is 32 years, and does not differ by level of skepticism. A mean of 27 percent of our sample auditors are female and these auditors exhibit lower HPS $(\mathrm{t}=-2.30$, $\mathrm{p}=0.021)$ and $P M C(\mathrm{t}=-1.80, \mathrm{p}=0.065)$ and higher $R I T(\mathrm{t}=2.10, \mathrm{p}=0.040)$ as compared to their male colleagues. Mean EXPERIENCE_YRS is 10 and does not differ by level of skepticism. Mean self-assessed AUDIT_KNOWLEDGE is 14 (and by valuation, fraud, and analytical procedures equal to 4.6,4.7, and 5.1, respectively); more-knowledgeable auditors have higher HPS (e.g., for total knowledge $t=3.80, p=0.000$ ) and $P M C$ (e.g., for total knowledge $t=3.10, p$ $=0.002$ ), but not higher RIT.

Descriptive statistics for the Big 5 personality traits are generally favorable (i.e., high on a 7point scale) with means as follows: EXTRAVERSION (4.6), AGREEABLENESS (4.0), CONSCIENTIOUSNESS (5.8), EMOTIONAL_STABILITY (5.4), and OPENNESS (4.9). ${ }^{21}$ Auditors who score higher on EXTRAVERSION ( $\mathrm{t}=3.70, \mathrm{p}=0.000 ; \mathrm{t}=2.40, \mathrm{p}=0.015)$, CONSCIENTIOUSNESS $(\mathrm{t}=4.80, \mathrm{p}=0.000 ; \mathrm{t}=3.80, \mathrm{p}=0.000)$, EMOTIONAL_STABILITY $(\mathrm{t}=$ 4.90, $\mathrm{p}=0.000 ; \mathrm{t}=2.40, \mathrm{p}=0.015)$, and OPENNESS $(\mathrm{t}=5.70, \mathrm{p}=0.000 ; 4.50, \mathrm{p}=0.00)$ have higher HPS and PMC, respectively, but not higher RIT. AGREEABLENESS does not differ by level of skepticism. Descriptive statistics for the Dark Triad traits are also generally favorable (i.e., low on a 7-point scale) with means as follows: MACHIAVELLIANISM (2.8), NARCISSISM (2.9),

21 Our sample of practicing auditors have relatively similar levels of EXTRAVERSION, AGREEABLENESS, and OPENNESS and somewhat higher levels of CONSCIENTIOUSNESS and EMOTIONAL_STABILITY compared to individuals from other studies (e.g., Ehrhart, Ehrhart, Roesch, Chung-Herrera, Nadler, and Bradshaw 2009; Romero, Gomez-Fraguela, and Lopez-Romero 2012; Isaacs, Mota, Tsai, Harpaz-Rotem, Cook, Kirwin, Krystal, Southwick, and Pietrzak 2017; Rouwelaar and DeLoo 2018; and Hardies 2019). 
and PSYCHOPATHY (2.1). ${ }^{22}$ Auditors who score higher on MACHIAVELLIANISM have lower HPS $(\mathrm{t}=-3.00, \mathrm{p}=0.003)$ and $P M C(\mathrm{t}=-3.70, \mathrm{p}=0.000)$, and higher $R I T(\mathrm{t}=1.80, \mathrm{p}=0.066)$ than other auditors. Auditors who score higher on NARCISSISM have higher HPS and PMC $(\mathrm{t}=$ 1.90, $\mathrm{p}=0.063 ; \mathrm{t}=2.10, \mathrm{p}=0.039$ ), while auditors who score higher on PSYCHOPATHY have lower HPS $(\mathrm{t}=-4.10, \mathrm{p}=0.000)$ and lower on $P M C(\mathrm{t}=-4.40, \mathrm{p}=0.000)$, but neither measure differs by $R I T$.

Table 2.3 Individual Differences, Personality Traits, Attitudes, Intentions, and Actions

\begin{tabular}{|c|c|c|c|c|c|}
\hline \multicolumn{6}{|c|}{ Panel A. Descriptive statistics } \\
\hline & Mean & Median & Std. Dev & $\underline{\text { Min }}$ & $\underline{\operatorname{Max}}$ \\
\hline \multicolumn{6}{|l|}{ Individual Differences: } \\
\hline$\overline{A G E}$ & 32 & 29 & 9.83 & 19 & 64 \\
\hline GENDER & 0.27 & 0 & 0.44 & 0 & 1 \\
\hline EXPERIENCE_YRS & 10 & 6 & 9.44 & 0 & 41 \\
\hline AUDIT_KNOWLEDGE & 14 & 15 & 3.38 & 3 & 21 \\
\hline KNOW_VALUATION & 4.6 & 5.0 & 1.42 & 1 & 7 \\
\hline KNOW_FRAUD & 4.7 & 5.0 & 1.33 & 1 & 7 \\
\hline KNOW_ANALYTICALPR & 5.1 & 5.0 & 1.10 & 1 & 7 \\
\hline \multicolumn{6}{|l|}{ Personality Traits: } \\
\hline EXTRAVERSION & 4.6 & 4.5 & 1.50 & 1 & 7 \\
\hline AGREEABLENESS & 4.0 & 4.0 & 0.85 & 1 & 7 \\
\hline CONSCIENTIOUSNESS & 5.8 & 6.0 & 0.96 & 2 & 7 \\
\hline EMOTIONAL_STABILITY & 5.4 & 5.5 & 1.13 & 2 & 7 \\
\hline OPENNESS & 4.9 & 5.0 & 1.06 & 1 & 7 \\
\hline MACHIAVELLIANISM & 2.8 & 2.9 & 0.58 & 1 & 5 \\
\hline NARCISSISM & 2.9 & 2.9 & 0.48 & 1.5 & 4 \\
\hline PSYCHOPATHY & 2.1 & 2.0 & 0.56 & 1 & 4 \\
\hline \multicolumn{6}{|c|}{ The Theory of Planned Behavior: } \\
\hline$\overline{A T T I T U D E}$ & 5.7 & 5.8 & 0.75 & 2 & 7 \\
\hline SN & 5.9 & 6.0 & 0.69 & 3 & 7 \\
\hline$P B C$ & 5.1 & 5.0 & 0.96 & 2 & 7 \\
\hline INTENTION & 6.2 & 6.0 & 0.71 & 3 & 7 \\
\hline \multicolumn{6}{|l|}{ Situational Characteristics: } \\
\hline$\overline{B I G \_4}$ & 0.5 & 1.0 & 0.50 & 0 & 1 \\
\hline CLIENT_IMPORTANCE & 4.1 & 4.0 & 1.46 & 1 & 7 \\
\hline$T O N E \_A T \_T O P$ & 21 & 22 & 4.13 & 4 & 28 \\
\hline BUDGET_PRESSURE & 11 & 11 & 3.96 & 3 & 21 \\
\hline \multicolumn{6}{|l|}{ Skeptical Actions: } \\
\hline 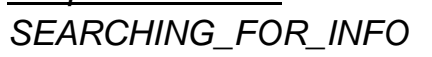 & 5.6 & 6.0 & 0.79 & 2 & 7 \\
\hline QUESTIONING & 5.4 & 5.7 & 0.84 & 2 & 7 \\
\hline SUSPENDING_JDGMT & 5.7 & 6.0 & 0.72 & 3 & 7 \\
\hline
\end{tabular}

${ }^{22}$ Our sample of practicing auditors have relatively similar levels of MACHIAVELLIANISM, NARCISSISM, and PSYCHOPATHY compared to individuals from other studies (e.g., Majors 2013; Hmieleski and Lerner 2016; Vedel and Thomsen 2017; Prusik and Szulawski 2019; Wissing and Reinhard 2019). 
Table 2.3 Individual Differences, Personality Traits, Attitudes, Intentions, and Actions (continued)

\begin{tabular}{|c|c|c|c|c|c|c|c|c|c|}
\hline \multicolumn{10}{|c|}{ Panel B. Variable Means by Skepticism Measures } \\
\hline \multicolumn{10}{|l|}{ Individual Differences: } \\
\hline$\overline{A G E}$ & 0.64 & 0.8 & 0.405 & 1.02 & 1.3 & 0.183 & -1.14 & -1.5 & 0.137 \\
\hline GENDER & -0.08 & -2.3 & 0.021 & -0.06 & -1.8 & 0.065 & 0.07 & 2.1 & 0.040 \\
\hline EXPERIENCE_YRS & 0.54 & 0.7 & 0.462 & 0.53 & 0.7 & 0.471 & -0.66 & -0.9 & 0.374 \\
\hline AUDIT_KNOWLEDGE & 0.99 & 3.8 & 0.000 & 0.81 & 3.1 & 0.002 & 0.05 & 0.2 & 0.837 \\
\hline KNOW_VALUATION & 0.31 & 2.8 & 0.005 & 0.34 & 3.1 & 0.002 & -0.02 & -0.2 & 0.856 \\
\hline KNOW_FRAUD & 0.31 & 3.0 & 0.003 & 0.24 & 2.3 & 0.020 & 0.01 & 0.1 & 0.904 \\
\hline KNOW_ANALYTICALPR & 0.37 & 4.3 & 0.000 & 0.22 & 2.6 & 0.009 & 0.06 & 0.7 & 0.468 \\
\hline \multicolumn{10}{|l|}{ Personality Traits: } \\
\hline$\overline{\text { EXTRAVERSION }}$ & 0.43 & 3.7 & 0.000 & 0.28 & 2.4 & 0.015 & 0.07 & 0.6 & 0.576 \\
\hline AGREEABLENESS & -0.07 & -1.1 & 0.272 & 0.00 & 0.0 & 0.971 & -0.10 & -1.4 & 0.149 \\
\hline CONSCIENTIOUSNESS & 0.35 & 4.8 & 0.000 & 0.28 & 3.8 & 0.000 & 0.11 & 1.4 & 0.155 \\
\hline EMOTIONAL_STABILITY & 0.42 & 4.9 & 0.000 & 0.21 & 2.4 & 0.015 & -0.13 & -1.5 & 0.137 \\
\hline OPENNESS & 0.46 & 5.7 & 0.000 & 0.36 & 4.5 & 0.000 & 0.06 & 0.7 & 0.498 \\
\hline MACHIAVELLIANISM & -0.14 & -3.0 & 0.003 & -0.17 & -3.7 & 0.000 & 0.08 & 1.8 & 0.066 \\
\hline NARCISSISM & 0.07 & 1.9 & 0.063 & 0.08 & 2.1 & 0.039 & -0.02 & -0.7 & 0.515 \\
\hline PSYCHOPATHY & -0.18 & -4.1 & 0.000 & -0.19 & -4.4 & 0.000 & -0.06 & -1.3 & 0.178 \\
\hline \multicolumn{10}{|c|}{ The Theory of Planned Behavior: } \\
\hline$\overline{A T T I T U D E}$ & 0.40 & 7.1 & 0.000 & 0.31 & 5.4 & 0.000 & 0.10 & 1.8 & 0.075 \\
\hline$S N$ & 0.30 & 5.8 & 0.000 & 0.28 & 5.3 & 0.000 & 0.00 & 0.0 & 0.996 \\
\hline$P B C$ & 0.29 & 3.9 & 0.000 & 0.18 & 2.5 & 0.014 & 0.18 & 2.4 & 0.018 \\
\hline $\begin{array}{l}\text { INTENTION } \\
\text { Situational Characteristics: }\end{array}$ & 0.44 & 8.6 & 0.000 & 0.38 & 7.1 & 0.000 & 0.16 & 2.8 & 0.005 \\
\hline$\overline{B I G \_4}$ & 0.09 & 2.3 & 0.022 & 0.16 & 4.1 & 0.000 & 0.02 & 0.4 & 0.660 \\
\hline CLIENTIIMPORTANCE & 0.08 & 0.7 & 0.456 & 0.19 & 1.7 & 0.096 & -0.10 & -0.9 & 0.379 \\
\hline$T O N E \_\bar{A} T \_T O P$ & 1.43 & 4.5 & 0.000 & 1.90 & 6.1 & 0.000 & 0.22 & 0.7 & 0.505 \\
\hline $\begin{array}{l}\text { BUDGET_PRESSURE } \\
\text { Skeptical Actions: }\end{array}$ & -0.38 & -1.2 & 0.214 & -0.69 & -2.3 & 0.024 & -0.16 & -0.5 & 0.598 \\
\hline 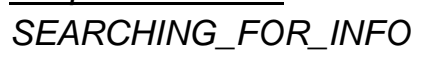 & 0.46 & 7.7 & 0.000 & 0.51 & 8.7 & 0.000 & 0.10 & 1.6 & 0.101 \\
\hline QUESTIONING & 0.58 & 9.5 & 0.000 & 0.45 & 7.2 & 0.000 & 0.16 & 2.5 & 0.012 \\
\hline SUSPENDING_JDGMT & 0.44 & 8.2 & 0.000 & 0.43 & 8.1 & 0.000 & 0.12 & 2.1 & 0.037 \\
\hline
\end{tabular}

This table summarizes the descriptive statistics for the professional skepticism measures and presents differences by rank. $H P S=$ Hurtt professional skepticism; $P M C=$ professional moral courage; $R I T=$ Rotter interpersonal trust, reverse scaled to indicate relative levels of distrust. Difference $\Delta=[$ mean $(\mathrm{HIGH})-$ mean $(\mathrm{LOW})]$ of the variables by high vs. low professional skepticism measures; p-values are two-tailed.

Variables relevant to the Theory of Planned Behavior indicate high levels of ATTITUDE (mean = 5.7), SN (mean = 5.9), PBC (mean = 5.1), and INTENTION (mean = 6.2) toward skepticism. Auditors who score higher on these variables also score significantly higher on professional skepticism with respect to HPS, PMC, and RIT, except that $S N$ is not associated with RIT. With respect to situational variables, we find that 50 percent of our sample are BIG_4 auditors, and 
that auditors in this category have higher levels of $\operatorname{HPS}(\mathrm{t}=2.30, \mathrm{p}=0.022)$ and $P M S(\mathrm{t}=4.10, \mathrm{p}$ $=0.000$ ), but not RIT. Mean CLIENT_IMPORTANCE is about four on a 7-point scale, and only marginally differs by $P M C(\mathrm{t}=1.70, \mathrm{p}=0.096)$. Mean TONE_AT_TOP equals 21 , which indicates a fairly high ethical tone at our sample audit firms, and auditors' perceptions of tone are better for more skeptical auditors in terms of HPS $(\mathrm{t}=4.50, \mathrm{p}=0.000)$ and $P M C(\mathrm{t}=6.10, \mathrm{p}=0.000)$, but not RIT. BUDGET_PRESSURE is moderate with a mean of 11 on a 21 -point scale, and is negatively associated with skepticism in terms of $P M C(\mathrm{t}=-2.30, \mathrm{p}=0.024)$, but not HPS or RIT. With respect to skeptical actions, we find that the means of SEARCHING_FOR_INFO, QUESTIONING, and SUSPENDING_JDGMT are each around 5.5 on a 7-point scale, and all are significantly higher for more-skeptical auditors.

\section{Correlations}

Table 2.4 presents correlations. Panel A provides results for the skepticism measures, individual differences, and personality traits. HPS and $P M C$ are significantly positively correlated ( $r=0.49$ ), whereas their correlations with RIT are insignificant. This suggests that $R I T$ is a distinct construct, which further explains why the inferences from some of the descriptive statistics for the HPS and PMC scales are different from the RIT scale. ${ }^{23}$ The correlations between HPS and PMC and the other variables are fairly consistent, with positive associations with $A G E$, EXPERIENCE_YRS, AUDIT_KNOWLEDGE, EXTRAVERSION, CONSCIENTIOUSNESS, EMOTIONAL_STABILITY, OPENNESS, NARCISSISM, and PARTNER rank; HPS and PMC are also negatively associated with MACHIAVELLIANISM, PSYCHOPATHY, and STAFF rank. RIT is negatively associated with AGE, EXPERIENCE, EMOTIONAL_STABILITY, and PARTNER rank; RIT is positively associated with MACHIAVELLIANISM. There is a high correlation between EXPERIENCE_YRS and AUDIT_KNOWLEDGE $(r=0.51)$, and both are positively associated with EMOTIONAL_STABILITY, OPENNESS, and the ranks of PARTNER and MANAGER; EXPERIENCE_YRS and AUDIT_KNOWLEDGE are negatively associated with MACHIAVELLIANISM and the rank of SENIOR. We find significant, positive associations among each of the Big 5 personality traits and among each of the Dark Triad personality traits.

${ }^{23}$ The results indicate that the three professional skepticism traits represent separate constructs. This is also confirmed by an untabulated factor analysis. 
Panel A. Professional Skepticism Measures, Individual Differences, and Personality Traits

\begin{tabular}{|c|c|c|c|c|c|c|c|c|c|c|c|c|}
\hline & $\begin{array}{l}\infty \\
\frac{n}{2}\end{array}$ & $\sum_{Q}^{O}$ & $\stackrel{\llcorner}{\boldsymbol{x}}$ & 岕 & 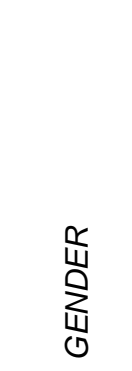 & 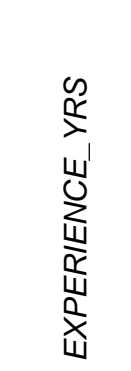 & 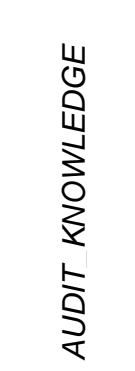 & 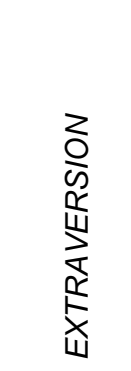 & 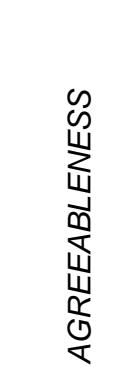 & 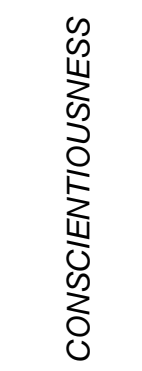 & 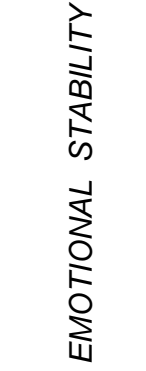 & $\begin{array}{l}\infty \\
\text { 岕 } \\
\substack{\mathbf{W} \\
0}\end{array}$ \\
\hline HPS & - & & & & & & & & & & & \\
\hline$P M C$ & $.4901^{*}$ & & & & & & & & & & & \\
\hline$R / T$ & .0595 & -.0730 & & & & & & & & & & \\
\hline$A G E$ & $.2095^{*}$ & $.3157^{\star}$ & $-.2048^{\star}$ & & & & & & & & & \\
\hline GENDER & -.0765 & $-.1208^{*}$ & .0919 & $-.2775^{\star}$ & & & & & & & & \\
\hline EXPERIENCE_YRS & $.1968^{*}$ & $.2992^{*}$ & $-.1838^{\star}$ & $.9413^{*}$ & $-.2432^{*}$ & & & & & & & \\
\hline AUDIT_KNOWLEDGE & $.2553^{*}$ & $.3368^{*}$ & -.0742 & $.4800^{\star}$ & $-.1707^{\star}$ & $.5051^{*}$ & & & & & & \\
\hline EXTRAVERSION & $.1760^{*}$ & $.1232^{*}$ & -.0047 & .0289 & .0782 & .0413 & $.1092^{*}$ & & & & & \\
\hline AGREEABLENESS & -.0379 & .0262 & -.0988 & $.1128^{*}$ & $.1134^{*}$ & .0875 & .0128 & .0638 & & & & \\
\hline CONSCIENTIOUSNESS & $.2596^{*}$ & $.2271^{*}$ & -.0031 & .0785 & $.1407^{\star}$ & .0736 & $.1061^{*}$ & .0375 & .0530 & & & \\
\hline EMOTIONAL_STABILITY & $.2214^{*}$ & $.1543^{*}$ & $-.1568^{\star}$ & .2526 & $-.2593^{*}$ & $.2426^{*}$ & $.1655^{\star}$ & -.0310 & .0390 & $.2404^{*}$ & & \\
\hline OPENNESS & $.3081^{*}$ & $.2499^{*}$ & -.0497 & $.1517^{\star}$ & -.0177 & $.1354^{*}$ & $.1321^{*}$ & $.3497^{\star}$ & .0387 & $.1227^{\star}$ & $.2014^{*}$ & \\
\hline MACHIAVELLIANISM & $-.1940^{*}$ & $-.1790^{*}$ & $.2011^{*}$ & $-.2138^{*}$ & -.0781 & $-.2195^{\star}$ & $-.1428^{\star}$ & -.0474 & -.0866 & $-.1723^{\star}$ & $-.1038^{\star}$ & $-.1384^{\star}$ \\
\hline PSYCHOPATHY & $-.2579^{*}$ & $-.2261^{*}$ & .0483 & $-.1635^{\star}$ & $-.1823^{*}$ & $-.1593^{*}$ & -.0571 & .0948 & $-.1374^{*}$ & $-.3856^{*}$ & $-.2227^{\star}$ & $-.1013^{\star}$ \\
\hline NARCISSISM & $.1003^{*}$ & $.1200^{*}$ & -.0405 & .0387 & $-.1063^{*}$ & .0489 & $.1149^{*}$ & $.3885^{\star}$ & .0340 & -.0573 & -.0016 & $.2570^{*}$ \\
\hline PARTNER & $.1772^{*}$ & $.2323^{*}$ & $-.1751^{*}$ & $.7622^{*}$ & $-.2257^{*}$ & $.7746^{*}$ & $.3501^{*}$ & $.1153^{*}$ & .0645 & $.1045^{\star}$ & $.2095^{\star}$ & $.1911^{*}$ \\
\hline MANAGER & .0462 & $.1001^{*}$ & .0065 & $.1141^{*}$ & -.0170 & $.1095^{\star}$ & $.2412^{*}$ & -.0309 & .0353 & -.0203 & .0210 & -.0560 \\
\hline SENIOR & -.0334 & -.0574 & .0976 & $-.2559^{\star}$ & .0533 & $-.2374^{\star}$ & -.0842 & -.0319 & -.0080 & - .0228 & -.0791 & -.0503 \\
\hline STAFF & $-.1661^{*}$ & $-.2436^{*}$ & .0684 & $-.5539^{\star}$ & $.1655^{\star}$ & $-.5739^{*}$ & $-.4512^{*}$ & -.0451 & -.0805 & -.0525 & $-.1362^{*}$ & -.0722 \\
\hline
\end{tabular}


Table 2.4 Correlation Matrix (continued)

Panel A. Professional Skepticism Measures, Individual Differences, and Personality Traits (continued)

\begin{tabular}{|c|c|c|c|c|c|c|}
\hline & 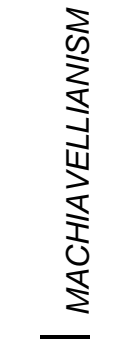 & 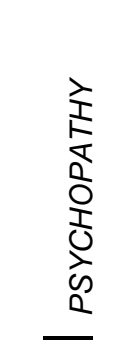 & 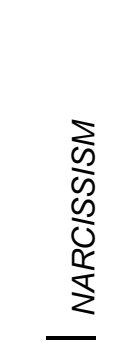 & 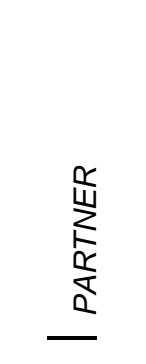 & 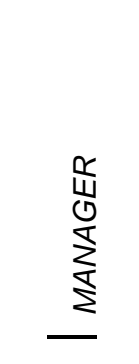 & $\sum_{\substack{\mathbf{W} \\
\mathrm{c}}}^{\frac{\pi}{2}}$ \\
\hline PSYCHOPATHY & $.4633^{*}$ & & & & & \\
\hline NARCISSISM & $.2175^{*}$ & $.3434^{\star}$ & & & & \\
\hline PARTNER & $-.1574^{*}$ & $-.1340^{*}$ & $.1093^{*}$ & & & \\
\hline MANAGER & $-.0703^{*}$ & .0131 & -.0142 & $-.3072^{\star}$ & & \\
\hline SENIOR & $.1041^{*}$ & .0702 & .0192 & $-.2209^{\star}$ & $-.2558^{*}$ & \\
\hline STAFF & $.1185^{*}$ & .0483 & -.0935 & $-.3969^{*}$ & $-.4596^{*}$ & $-.3305^{*}$ \\
\hline
\end{tabular}


HPS

\section{$P M C$}

RIT

ATTITUDE

$S N$

$P B C$

INTENTION

BIG_4

CLIENT_IMPORTANCE

TONE_AT_TOP

BUDGET_PRESSURE

SEARCHING_FOR_INF

QUESTIONING

SUSPENDING_JDGMT

$$
\text { 告 }
$$$$
\stackrel{0}{\infty} \quad \stackrel{\frac{1}{x}}{-}
$$$$
\text { \& }
$$
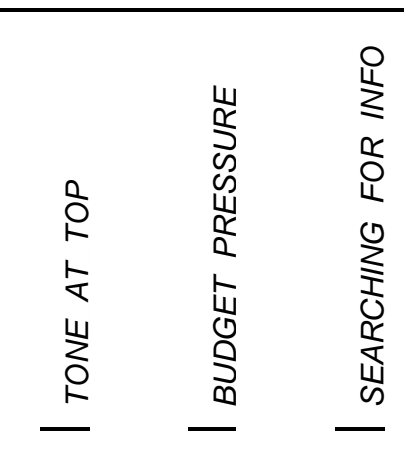

$.0595-.0730$

$\begin{array}{lll}.3276^{*} & .2338^{*} \quad .0588\end{array}$

$.3419^{*} \quad .3300^{*}-.0772$

$.3020^{*} \quad .2291^{*} \quad .0466$

$.4362^{*} \quad .3561^{*} \quad .0335$

$\begin{array}{lll}.1139^{*} & .1463^{*} & .0254 \\ .0259 & .0764 & -.0121\end{array}$

$.0259 \quad .0764-.0121$

$.2598^{*} \quad .2991^{*}-.1153^{*}$

$0880-1193^{*}-0358$

$\begin{array}{lll}.3926^{*} & .4237^{*} & .0244\end{array}$

$.4272^{*} \quad .3368^{*} \quad .0627$

$.4479^{*} \quad .4331^{*} \quad .0073$

$.3516^{*}$

$.3513^{*}$

$4077^{*}$

$\begin{array}{lll}.1439^{*} & .1421^{*} \quad .0676 \\ .0202 & -.0098 & .0852\end{array}$

$.0202-.0098 \quad .0852$

$\begin{array}{lllll}.1941^{*} & .4315^{*} & .2548^{*} & .2650^{*} & .1505^{*}\end{array}$

$-.1617^{\star}-.2778^{\star}-.1493^{\star}-.1545^{\star}-.0862$

$\begin{array}{lllll}.2378^{*} & .3367^{*} & .2300^{*} & .3091^{*} & .1343^{*}\end{array}$

$\begin{array}{lllll}.2107^{*} & .2685^{*} & .1614^{*} & .2735^{*} & .1632^{*}\end{array}$

$\begin{array}{lllll}.2909^{*} & .3539^{*} & .2443^{*} & .3560^{*} & .1531^{*}\end{array}$
.0028

$.0772-.2640$

$.1067^{*} \quad .2779^{*}-.1190^{\star}$

$\begin{array}{llll}.0391 & .2156^{*}-.0451 & .6141^{*}\end{array}$

$\begin{array}{lllll}.0611 & .3012^{*} & -.0897 & .7293^{*} & .6717^{*}\end{array}$

This table presents the correlation matrix. ${ }^{*}$ significant at 0.01 level; $p$-values are two-tailed. See Appendix I for variable definitions. 
Table 2.4 Panel B provides correlations with respect to measures of the Theory of Planned Behavior, situational characteristics, and skeptical actions. HPS and PMC both are positively associated with ATTITUDE, SN, PBC, INTENTION, BIG_4, TONE_AT_TOP, SEARCHING_FOR_INFO, QUESTIONING, and SUSPENDING_JDGMT; in contrast, the only significant correlation for $R I T$ is a negative association with TONE_AT_TOP. Regarding situational characteristics, BIG_4 is positively associated with TONE_AT_TOP and each of the three skeptical actions.

\section{Research Questions}

Table 2.5 presents results of structural equation testing for our conceptual model. ${ }^{24}$ Regarding RQ1a, we find that individual differences affect professional skepticism traits in various respects. We have no directional expectation regarding GENDER, but find that female auditors have lower HPS $(\mathrm{t}=-2.03, \mathrm{p}=0.042)$ and PMC $(\mathrm{t}=-2.89, \mathrm{p}=0.004)$, but GENDER is not associated with $R I T$. Given mixed evidence in prior research, we have no directional expectation between experience and skepticism traits, and find that auditors with more EXPERIENCE_YRS have higher $P M C(\mathrm{t}=2.55, \mathrm{p}=0.011)$, but lower $R I T(\mathrm{t}=-2.75, \mathrm{p}=0.006)$. We anticipate a positive association regarding task-specific AUDIT_KNOWLEDGE, and find that more knowledgeable auditors have higher HPS $(\mathrm{t}=3.83, \mathrm{p}=0.000)$ and $P M C(\mathrm{t}=5.19, \mathrm{p}=0.000)$, but there is no association with $R I T$. Thus, female auditors are less skeptical and auditors with more knowledge are more skeptical, while the results for experience are mixed. ${ }^{25}$

Regarding RQ1b and with respect to the Big Five personality traits, auditors with greater EXTRAVERSION have greater HPS $(\mathrm{t}=2.27, \mathrm{p}=0.023)$, while auditors who score higher on AGREEABLENESS are less skeptical (HPS: $\mathrm{t}=-2.58, \mathrm{p}=0.010 ; R I T: \mathrm{t}=-2.10, \mathrm{p}=0.035$ ); both results are consistent with our expectations. Auditors with greater CONSCIENTIOUSNESS are more skeptical (HPS: $\mathrm{t}=3.58, \mathrm{p}=0.000 ; P M C: \mathrm{t}=3.50, \mathrm{p}=0.000$ ), as are those with greater OPENNESS (HPS: $\mathrm{t}=4.70, \mathrm{p}=0.000$; PMC: $\mathrm{t}=3.56, \mathrm{p}=0.000$ ), also consistent with our expectations. Auditors with greater EMOTIONAL_STABILITY have lower RIT $(\mathrm{t}=-2.96, \mathrm{p}=$ $0.003)$, which is in contrast to our expectations. In terms of the Dark Triad, the results reveal that

24 We calculate various goodness-of-fit measures, which collectively provide strong support for our conceptual model: $X^{2}(120)=642.65, p=0.001$; RMSEA $=0.081$ (confidence interval at $90 \%=0.075-0.087$ ); $\mathrm{CFI}=0.81 ; \mathrm{SRMR}=$ 0.076 (Hooper, Coughlan, and Mullen 2008; Kline 2016). Because of the high correlation between AGE and EXPERIENCE_YRS, we only include EXPERIENCE_YRS in the hypothesis-testing model; results remain essentially the same if we include $A G E$ rather than EXPERIENCE_YRS.

25 As we observe significant differences between ranks, especially for the individual differences, we run additional analyses at subsamples of different ranks to rule out that our result are driven by our sample composition. Overall, we find similar results, indicating that personality and individual differences are associated with especially HPS and $P M C$. However, we do not find an effect for GENDER at partner level. 
auditors who score higher on MACHIAVELLIANISM have higher levels of $R I T(\mathrm{t}=5.07, \mathrm{p}=0.000)$, and those with greater NARCISSISM also have higher trait skepticism (HPS: $\mathrm{t}=2.11, \mathrm{p}=0.035$; $P M C: \mathrm{t}=2.85, \mathrm{p}=0.004)$; both results are consistent with our expectations. Auditors with greater PSYCHOPATHY have lower skepticism (HPS: $\mathrm{t}=-4.63, \mathrm{p}=0.000 ; P M C: \mathrm{t}=-4.26, \mathrm{p}=0.000$ ), which is consistent with the theory underlying our expectation in this regard. Taken together, we find that more skeptical auditors tend to be extraverted, conscientious, open to new experiences, and express greater Machiavellianism and narcissism. They also tend to be less agreeable, less emotionally stable, and less psychopathic. Overall, we find theoretically consistent relationships between individual differences and personality traits for the skepticism measures HPS and PMC, while these relationships are less consistent for RIT.

Table 2.5 Determinants of Skepticism, Attitudes, Intentions, and Skeptical Actions

\begin{tabular}{|c|c|c|c|c|}
\hline \multirow[t]{2}{*}{ Independent variables } & \multirow[b]{2}{*}{$\begin{array}{c}\text { Predicted } \\
\text { Relationship }\end{array}$} & \multicolumn{3}{|c|}{ Dependent variables } \\
\hline & & HPS & $P M C$ & $R I T$ \\
\hline \multicolumn{5}{|c|}{ Individual Differences (RQ1a): } \\
\hline GENDER & $+1-$ & $\begin{array}{c}-1.861^{* \star} \\
{[-2.03]}\end{array}$ & $\begin{array}{c}-2.651^{* * *} \\
{[-2.89]}\end{array}$ & $\begin{array}{l}0.692 \\
{[0.86]}\end{array}$ \\
\hline EXPERIENCE_YRS & $+/-$ & $\begin{array}{l}0.009 \\
{[0.20]}\end{array}$ & $\begin{array}{l}0.119^{* *} \\
{[2.55]}\end{array}$ & $\begin{array}{c}-0.112^{* * *} \\
{[-2.75]}\end{array}$ \\
\hline AUDIT_KNOWLEDGE & + & $\begin{array}{l}0.478^{* * *} \\
{[3.83]}\end{array}$ & $\begin{array}{l}0.650^{* * *} \\
{[5.19]}\end{array}$ & $\begin{array}{l}0.107 \\
{[0.98]}\end{array}$ \\
\hline \multicolumn{5}{|l|}{ Personality Traits (RQ1b): } \\
\hline EXTRAVERSION & + & $\begin{array}{l}0.626^{* *} \\
{[2.27]}\end{array}$ & $\begin{array}{l}0.166 \\
{[0.60]}\end{array}$ & $\begin{array}{l}0.180 \\
{[0.74]}\end{array}$ \\
\hline AGREEABLENESS & - & $\begin{array}{c}-1.114^{* \star *} \\
{[-2.58]}\end{array}$ & $\begin{array}{l}-0.231 \\
{[-0.60]}\end{array}$ & $\begin{array}{l}-0.794^{\star *} \\
{[-2.10]}\end{array}$ \\
\hline CONSCIENTIOUSNESS & + & $\begin{array}{l}1.506^{\star * *} \\
{[3.58]}\end{array}$ & $\begin{array}{c}1.476^{* * *} \\
{[3.50]}\end{array}$ & $\begin{array}{l}0.317 \\
{[0.86]}\end{array}$ \\
\hline EMOTIONAL_STABILIY & + & $\begin{array}{l}0.572 \\
{[1.59]}\end{array}$ & $\begin{array}{l}-0.356 \\
{[-0.99]}\end{array}$ & $\begin{array}{l}-0.937^{\star \star *} \\
{[-2.96]}\end{array}$ \\
\hline OPENNESS & + & $\begin{array}{l}1.797^{\star \star \star} \\
{[4.70]}\end{array}$ & $\begin{array}{c}1.366^{* * *} \\
{[3.56]}\end{array}$ & $\begin{array}{l}0.138 \\
{[0.41]}\end{array}$ \\
\hline MACHIAVELLIANISM & + & $\begin{array}{l}-0.892 \\
{[-1.24]}\end{array}$ & $\begin{array}{l}-0.639 \\
{[-0.89]}\end{array}$ & $\begin{array}{l}3.195^{\star * *} \\
{[5.07]}\end{array}$ \\
\hline NARCISSISM & + & $\begin{array}{l}1.893^{\star *} \\
{[2.11]}\end{array}$ & $\begin{array}{c}2.564^{* * *} \\
{[2.85]}\end{array}$ & $\begin{array}{l}-1.293 \\
{[-1.64]}\end{array}$ \\
\hline PSYCHOPATHY & - & $\begin{array}{l}-3.891^{* \star *} \\
{[-4.63]}\end{array}$ & $\begin{array}{c}-3.588^{* * *} \\
{[-4.26]}\end{array}$ & $\begin{array}{l}-0.985 \\
{[-1.34]}\end{array}$ \\
\hline
\end{tabular}


Table 2.5 Determinants of Skepticism, Attitudes, Intentions, and Skeptical Actions (continued)

\begin{tabular}{|c|c|c|c|c|}
\hline \multicolumn{5}{|c|}{ Panel B. Attitudes, Intentions, Situational Characteristics, and Skeptical Actions } \\
\hline \multirow[t]{3}{*}{ Independent variables } & \multirow{3}{*}{$\begin{array}{c}\text { Predicted } \\
\text { Relationship } \\
\end{array}$} & \multicolumn{3}{|c|}{ Dependent variables } \\
\hline & & ATTITUDE & $S N$ & $P B C$ \\
\hline & & H1a & H1b & H1c \\
\hline \multirow[t]{2}{*}{ HPS } & + & $0.027^{\star \star *}$ & $0.018^{\star \star *}$ & $0.012^{* * *}$ \\
\hline & & {$[6.51]$} & {$[6.00]$} & {$[5.76]$} \\
\hline \multirow[t]{2}{*}{$P M C$} & + & $0.010^{\star \star \star}$ & $0.015^{\star \star \star}$ & $0.006^{\star \star \star}$ \\
\hline & & {$[2.45]$} & [4.94] & [2.64] \\
\hline \multirow[t]{2}{*}{$R I T$} & + & 0.006 & $-0.007^{* *}$ & 0.003 \\
\hline & & {$[1.36]$} & {$[-2.14]$} & {$[1.08]$} \\
\hline \multicolumn{5}{|c|}{ INTENTION } \\
\hline ATTITUDE $\mathbf{H 2 a}$ & + & $\begin{array}{c}0.138^{\star \star \star} \\
{[5.99]}\end{array}$ & & \\
\hline \multirow[t]{2}{*}{$S N$} & + & $0.420^{* * \star}$ & & \\
\hline & & [13.80] & & \\
\hline \multirow[t]{4}{*}{$P B C$} & + & $0.170^{* * *}$ & & \\
\hline & & {$[3.86]$} & & \\
\hline & & $\begin{array}{l}\text { SEARCHING_ } \\
\text { FOR_INFO }\end{array}$ & QUESTIONING & $\begin{array}{c}\text { SUSPENDING } \\
\text { JDGMT }\end{array}$ \\
\hline & & H3a & $H 3 b$ & $\mathrm{H} 3 \mathrm{c}$ \\
\hline \multirow[t]{2}{*}{ INTENTION } & + & $0.141^{\star \star \star}$ & $0.156^{\star \star *}$ & $0.200^{* * *}$ \\
\hline & & {$[2.74]$} & [2.85] & [3.61] \\
\hline \multicolumn{5}{|l|}{ Situational Characteristics: } \\
\hline \multirow[t]{2}{*}{ BIG_4 } & + & $0.099^{*}$ & $0.176^{\star \star \star}$ & $0.120^{* \star}$ \\
\hline & & {$[1.72]$} & {$[2.86]$} & {$[1.92]$} \\
\hline \multirow[t]{2}{*}{ CLIENT_IMPORTANCE } & + & $0.055^{\star \star \star}$ & 0.021 & 0.033 \\
\hline & & {$[2.83]$} & {$[1.00]$} & {$[1.57]$} \\
\hline \multirow[t]{2}{*}{$T O N E \_A T \_T O P$} & + & $0.027^{\star \star \star}$ & $0.023^{\star \star \star}$ & $0.036^{\star \star \star}$ \\
\hline & & {$[3.51]$} & {$[2.71]$} & {$[4.30]$} \\
\hline \multirow[t]{2}{*}{ BUDGET_PRESSURE } & - & -0.001 & 0.011 & 0.009 \\
\hline & & {$[-0.07]$} & {$[1.40]$} & {$[1.15]$} \\
\hline \multicolumn{5}{|c|}{$\begin{array}{l}\text { This table reports the standardized coefficients of the full SEM analysis and the [t-scores]. }{ }^{*},{ }^{* *} \text { and }{ }^{* * *} \text { significant at } \\
\text { respectively } 0.10,0.05 \text { and } 0.01 \text { level. See Appendix I for variable definitions. } \\
X^{2}(120)=642.65, p=0.001 ; \text { RMSEA }=0.081(\mathrm{Cl} \text { at } 90 \%=0.075-0.087) ; \mathrm{CFI}=0.81 ; \text { SRMR }=0.076\end{array}$} \\
\hline
\end{tabular}

\section{Hypothesis-Testing}

Hypotheses 1a-c predict and our results, shown in Table 2.5 Panel B and Figure 2.2, largely support that professional skepticism traits are positively associated with attitudes toward, subjective norms about, and intentions to act skeptically. Specifically, HPS and PMC are each positively associated with ATTITUDE $(\mathrm{t}=6.51, \mathrm{p}=0.000 ; \mathrm{t}=2.45, \mathrm{p}=0.014$, respectively $), S N(\mathrm{t}$ 
$=6.00, \mathrm{p}=0.000 ; \mathrm{t}=4.94, \mathrm{p}=0.000$, respectively $)$, and $P B C(\mathrm{t}=5.76, \mathrm{p}=0.000 ; \mathrm{t}=2.64, \mathrm{p}=$ 0.008 , respectively); an exception is that $R I T$ is negatively associated with $S N(\mathrm{t}=-2.14, \mathrm{p}=$ 0.032). Hypotheses $2 \mathrm{a}-\mathrm{c}$ predict and our results support that $A T T I T U D E(\mathrm{t}=5.99, \mathrm{p}=0.000), S N$ $(\mathrm{t}=13.80, \mathrm{p}=0.000)$ and $P B C(\mathrm{t}=3.86, \mathrm{p}=0.000)$ are each positively associated with auditors' INTENTIONs to act skeptically. A comparison of the coefficients of ATTITUDE, SN and PBC shows that subjective norms (i.e., social pressure) have the largest impact on auditors' intentions. Finally, Hypotheses 3a-c predict and our results support that auditors' INTENTIONs to act skeptically are, indeed, positively associated with auditors' reports of acting professionally in practice with respect to SEARCHING_FOR_INFO $(\mathrm{t}=2.74, \mathrm{p}=0.006)$, QUESTIONING $(\mathrm{t}=2.85$, $\mathrm{p}=0.004)$, and SUSPENDING_JDGMT $(\mathrm{t}=3.61, \mathrm{p}=0.000)$.

We also estimate direct effects from each of the measures of the Theory of Planned Behavior to skeptical actions. The results are as follows (coefficient, two-tailed p-value): ATTITUDE to SEARCHING_FOR_INFO (0.058, 0.062), QUESTIONING $(0.073, \quad 0.033)$, SUSPENDING_JDGMT $(0.111,0.001)$; SUBJECTIVE_NORM to SEARCHING_FOR_INFO (0.155, $\mathrm{p}=0.001)$, QUESTIONING (0.123, $\mathrm{p}=0.019)$, SUSPENDING_JDGMT $(0.167, \mathrm{p}=0.002)$; $P B C$ to SEARCHING_FOR_INFO (0.089, $\mathrm{p}=0.124)$, QUESTIONING $(0.026, \mathrm{p}=0.679)$, SUSPENDING_JDGMT $(0.096, \mathrm{p}=0.137)$.

With respect to control variables for situational characteristics, we predict and find that BIG_4 auditors and those whose audit firms have an ethical TONE_AT_TOP act more skeptically with respect to SEARCHING_FOR_INFO $(\mathrm{t}=1.72, \mathrm{p}=0.085 ; \mathrm{t}=3.51, \mathrm{p}=0.000$, respectively), QUESTIONING ( $\mathrm{t}=2.86, \mathrm{p}=0.004 ; \mathrm{t}=2.71, \mathrm{p}=0.007$, respectively), and SUSPENDING_JDGMT $(\mathrm{t}=1.92, \mathrm{p}=0.055 ; \mathrm{t}=4.30, \mathrm{p}=0.000$, respectively $)$. We also predict and find that CLIENT_IMPORTANCE is positively associated with skeptical action, but only with respect to SEARCHING_FOR_INFO ( $\mathrm{t}=3.51, \mathrm{p}=0.005)$. In contrast to our expectations, BUDGET_PRESSURE appears to have no association with skeptical actions. ${ }^{26}$

26 In an additional analysis, we further extend the model. We include direct effects of the professional skepticism traits on intention and skeptical actions, and direct effects of personality and individual differences on attitude, subjective norm, perceived behavioral control, intention and skeptical actions. Overall, the effects tested in the main analysis remain similar. Further, we find a significant positive effect of HPS and PMC (coefficient, two-tailed p-value for HPS and PMC respectively) on INTENTION $(0.013, p=0.000 ; 0.006, p=0.009)$ and the skeptical actions SEARCHING_FOR_INFO $(0.011, \mathrm{p}=0.001 ; 0.017, \mathrm{p}=0.000)$, QUESTIONING $(0.022, \mathrm{p}=0.000 ; 0.010, \mathrm{p}=0.004)$, and SUSPENDING_JDGMT $(0.018, \mathrm{p}=0.000 ; 0.016, \mathrm{p}=0.000)$, while we find no direct effect of RIT. We find no consistent relationships between personality and individual differences and attitude, subjective norm, perceived behavioral control, intention and skeptical actions $\left[X^{2}(31)=254.202, p=0.001\right.$; RMSEA $=0.104$ (confidence interval at $90 \%=0.093-0.116) ; \mathrm{CFI}=0.92 ; \mathrm{SRMR}=0.038]$. 


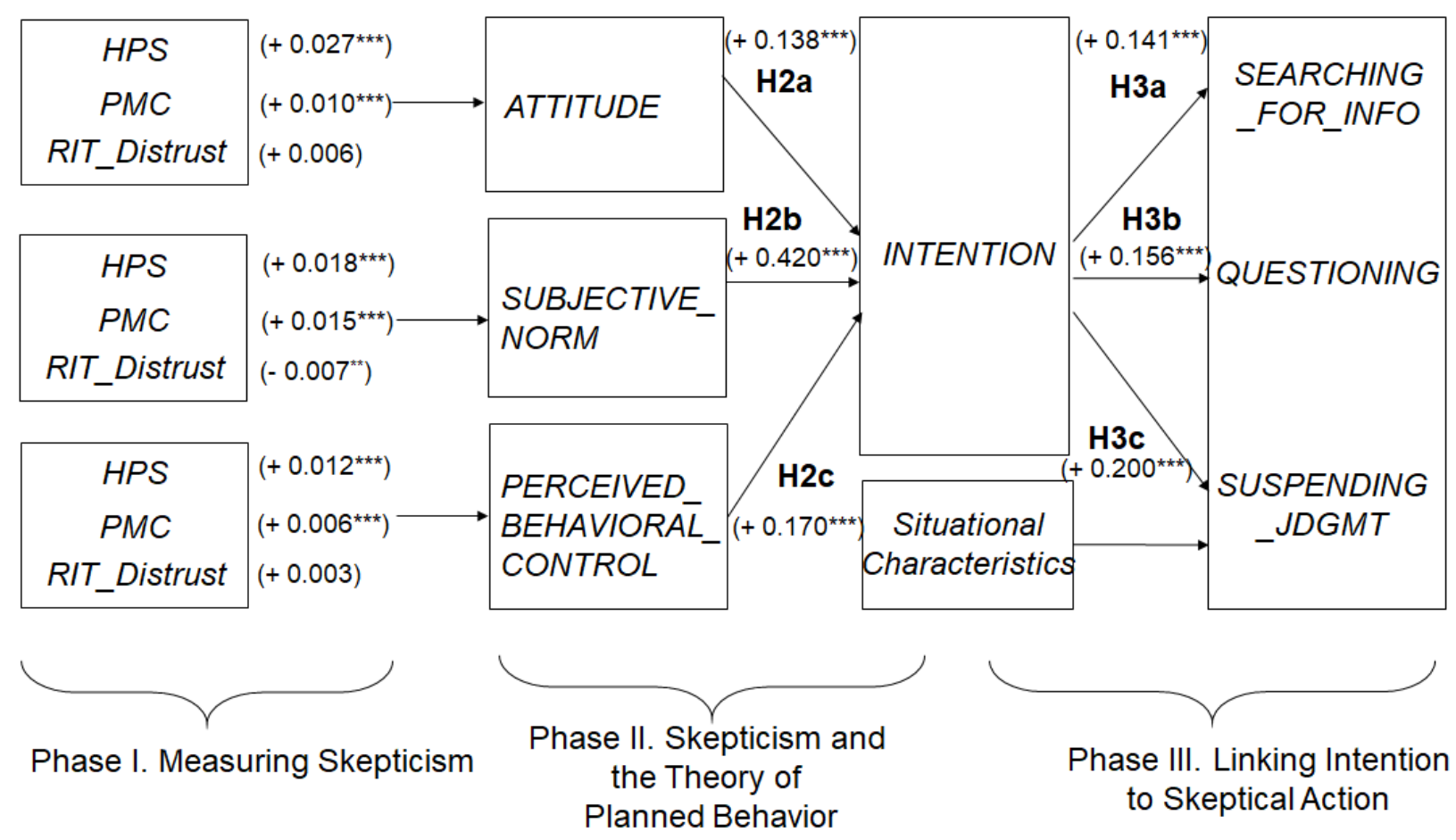

Figure 2.2 Determinants of Attitudes toward, and Intentions about Professional Skepticism

\subsection{CONCLUSIONS, LIMITATIONS AND DIRECTIONS FOR FUTURE RESEARCH}

We provide an answer to calls from prior research to provide empirical tests on individual auditor characteristics (e.g., DeFond and Zhang 2014) and to calls from researchers introducing various conceptual models of auditors' professional skepticism and its associations with attitudes, intentions and skeptical actions (e.g., Nolder and Kadous 2018). The results reveal evidence in support of using HPS (Hurtt 2010, which adopts a neutral perspective) and professional moral courage (PMC; Sekerka et al. 2009) to measure professional skepticism traits. The results provide insights with respect to various measures of professional skepticism: the Hurtt Professional Skepticism scale (HPS, which adopts a neutral perspective), the Professional Moral Courage scale (PMC, which focuses on taking skeptical action), and Rotter's Interpersonal Trust scale (RIT, which adopts a presumptive doubt perspective), so the inferences we draw are wide-ranging in their application. Further, we cannot emphasize enough the unique and valuable contribution that our data provide. Sensitive psychometric data is particularly difficult to obtain and audit firms, especially in the US, are often reluctant to approve its collection by researchers; obtaining this 
data across all ranks and multiple audit firms is also unusual and therefore yields valuable insights.

We advance the Theory of Planned Behavior in an auditing context, showing that behaviors underlying professional skepticism traits, and in particular those relating to HPS and PMC, are positively associated with attitudes, subjective norms, and perceived behavioral control over skepticism, which in turn affect auditors' intentions to act skeptically. Our results also have practical implications in that they may assist with designing effective interventions to improve auditors' professional skepticism. While the Theory of Planned Behavior does not provide specific guidance on the types of interventions that may be most effective (e.g., enhancing partner communication [Harding and Trotman 2017], improving evaluation and reward systems [Brazel et al. 2016], or changing auditors' mindsets [Griffith, Hammersley, Kadous, and Young 2015]), it does help to identify where to target behavioral interventions. From a practice-advancing perspective concerning potential interventions to foster professional skepticism, we find that subjective norms (i.e., social pressure) are the strongest predictor of auditors' intentions to act skeptically. Subjective norms relate to how individuals feel about and respond to pressure from others, so those considering using interventions to improve skeptical intentions and actions will most profitably employ some element of this construct. Our results also speak to criticisms by regulators who claim that auditors often lack professional skepticism. We find strong evidence that auditors both intend to act skeptically and then do believe that they are acting skeptically with respect to evidence collection and evaluation. This would suggest that there is a disconnect between auditors' and regulatory inspectors' views about what constitutes skeptical actions. Understanding and proposing theoretically grounded remedies for this disconnect are an important avenue for future research inquiry. Toward this end, future research might assess the behavioral, normative, and control beliefs underlying auditors' attitudes, subjective norms, and perceived behavioral control towards professional skepticism in order to guide the design of behavioral interventions to align the views of auditors and inspectors.

There exist certain limitations of our research. First, we cannot completely control for client characteristics, although we do include a rough proxy for size and complexity based on our measure of client importance. Second, due to client-confidentiality constraints, we were not allowed to directly oversee the selection of our sample selection process, and the sample selection is biased in that we requested that participating firms begin their selections by first choosing partners whose engagements were to be the subject of within-firm inspection. Each audit firm likely has different processes for selecting engagements for within-firm inspection and the role of such processes is unclear as to potential effects on our inference; however, when we 
remove such firms, we obtain essentially identical results. Third, our data comes from each individual auditor's perceptions of and recalls about past client engagement experiences, which may yield inaccuracy since these perceptions are an internal state. Other members of the team might have made different assessments (Ericsson and Simon 1980). Fourth, we cannot unequivocally determine the causality underlying our inferences. The results reveal that skepticism is increasing in auditors' task knowledge. Future research might try to determine if auditors with higher trait skepticism are more likely to stay in public accounting and are more likely to get promoted to partner, or if auditors become more professionally skeptical as they evolve with changing leadership roles within the firms over time. 



\title{
Chapter 3. Process factors
}

\begin{abstract}
Auditing standards emphasize that fraud detection is an important objective of an audit and require the exercise of professional skepticism (PS) and a discussion among the engagement team to prevent and detect fraud. The purpose of this study is to examine whether professional skepticism is a driver of fraud brainstorming quality. We investigate the relationship between fraud brainstorming quality, using the measure of Brazel et al. (2010), and auditor's professional skepticism traits. Using proprietary data from Dutch audit firms on 125 engagements, we find that neutral trait skepticism and professional moral courage of the partner have a significant effect on fraud brainstorming quality. We observe a higher attendance rate and contribution of specialists, more extensive discussion, longer preparation, and longer sessions for engagements led by partners with high neutral trait skepticism and high moral courage. We find no significant results for partners with a high presumptive doubt trait. Additional cross-sectional analyses show that the effect of professional skepticism on FBQ depends on situational, organizational conditions.
\end{abstract}

This chapter is based on a working paper. I thank Kris Hardies, Ann Vanstraelen, and Karla Zehms for their helpful comments on the paper.

I would like to thank the Foundation for Auditing Research for their grant 2016B05. Furthermore, I would like to thank all participants and data providing firms. The views expressed in this paper are my views and do not necessarily reflect the views of the Foundation for Auditing Research. 


\subsection{INTRODUCTION}

This paper examines the role of professional skepticism as a driver of fraud brainstorming quality. Fraud has important economic and social consequences, harming financial statement users' trust and social integrity (AFM 2018). Auditing standards therefore require auditors to explicitly consider the risks of material misstatements due to fraud (e.g., SAS No. 99; ISA 240). Specifically, auditing standards require a discussion among the engagement team regarding the risks of material misstatements due to fraud (i.e., fraud brainstorming) ${ }^{27}$ Auditing standards also emphasize the need for auditors to exercise professional skepticism throughout the audit and particularly when considering the risk of material misstatements due to fraud (e.g., AS 2110; ISA 240; SAS. No. 99). ${ }^{28}$

Prior literature has focused on fraud brainstorming practices after the initial implementation of SAS No. 99 (Bellovary and Johnstone 2007; Brazel et al. 2010; Dennis and Johnstone 2016). To the best of our knowledge, prior research has not paid any attention to the drivers of fraud brainstorming quality. Understanding the drivers of fraud brainstorming quality is, however, important because it is an important element of the audit process, as it enables the identification of fraud risk factors and associated audit responses (Carpenter 2007, Hoffman and Zimbelman 2009; Lynch et al. 2009; Trotman et al. 2009; Chen et al. 2015). In this study, we focus on professional skepticism as a potential driver of fraud brainstorming quality. Professional skepticism is considered a key input factor to the audit process to support a quality audit (IAASB 2015). The importance of professional skepticism is widely and indisputably recognized both by regulators (e.g., PCAOB 2015b; IFIAR 2015), standard setters (e.g., IAASB 2017), practitioners (e.g., ICAEW 2018), and academics (e.g., Brazel and Schaefer, 2015; Nolder and Kadous, 2018). However, there is little research that has investigated which audit processes are affected by professional skepticism and how professional skepticism affects these processes. Prior literature has studied the effect of auditor's professional skepticism on fraud detection in experimental settings (for an overview see Brazel and Schaefer, 2015), but there is no research that investigated the effect of professional skepticism on fraud brainstorming quality. Therefore, the purpose of this study is to examine the relationship between professional skepticism, more specifically the partner's professional skepticism traits, and fraud brainstorming quality.

27 While SAS No. 99 refers to brainstorming specifically, ISA 315 simply refers to "a discussion" and does not stipulate the type of group discussion (Trotman et al. 2009). The intention and general wording of both standards are, however, similar.

28 A lack of professional skepticism is also regularly cited in inspection reports as a problem for auditors' fraud assessments (e.g., PCAOB 2008). 
Our study provides several incremental contributions to prior fraud brainstorming and professional skepticism research, and to the broader psychological literature on group decision making. First, our study is the first to investigate the effect of professional skepticism on fraud brainstorming quality. As a higher fraud brainstorming quality leads to better fraud risk identification and more effective audit plans to identify misstatements due to fraud, fraud brainstorming quality indirectly affects audit quality. With the results of our study we provide insights regarding fraud brainstorming practices under ISA 240 and compare this with insights from the US setting. Further, to investigate the effect of professional skepticism, we include both individual and social characteristics which together form an auditor's professional skepticism to enable us to make the distinction between the effect of professional skepticism traits and the effect of other characteristics of professional skepticism. Next, our study is the first to examine differences in fraud brainstorming quality and the underlying items across professional skepticism traits partitions. Investigating the underlying items across these partitions allow us to make recommendations for improving fraud brainstorming in practice. Thus, the result of our study are not only relevant for the academic literature, but also for audit practice, standard setters and regulators. Given that professional skepticism traits are inherent and relatively stable over time, the results of this study might, for example help audit firms in selecting and training their people. Last, brainstorming has been studied within auditing (see, e.g., Trotman, Bauer, and Humphreys 2015), and within the broader psychological literature on group decision making (see, e.g., Brown and Paulus 2002; Kerr and Tindale 2004). The focus of this body of research has, however, been heavily on whether groups outperform individuals, and on the impact of group size and the method of brainstorming (e.g., electronic, nominal). Furthermore, participants in these psychological studies are most often unexperienced novices such as students, while participants in fraud brainstorming are experienced professionals. With the results of our study, based on data of 125 audit partners, we contribute to the broader psychological literature on group decision making by investigating drivers of brainstorming.

While prior research has provided some evidence on auditor professional skepticism and fraud identification and detection in experimental settings, there is no empirical evidence on how the professional skepticism traits of an auditor might affect fraud brainstorming sessions in practice as an important scientific challenge is the lack of availability of actual data from the field. For this study, we were able to go inside the "black box" of individuals, audit teams and the audit process. We sent out a survey to auditors in different engagement teams, and in different firms. This provides us with unique data to examine the fraud brainstorming quality and the effect of professional skepticism traits on fraud brainstorming quality. 


\section{4 | CHAPTER 3}

Analyzing a sample of 125 engagements from five Dutch audit firms (two Big 4 and three nonBig 4) relating to the year 2016, the result show that neutral trait skepticism and professional moral courage of the partner have a significant effect on fraud brainstorming quality. More specifically, we observe higher attendance rate and contribution of specialists, more extensive discussion, longer preparation, and longer sessions for partners with high neutral trait skepticism and high moral courage. We find no significant results for partners with a high presumptive doubt trait. Next, we find cross-sectional evidence showing that the effect of professional skepticism traits on fraud brainstorming quality depends on organizational conditions. We find that professional moral courage of the partner has an effect on fraud brainstorming quality in firms with a positive performance evaluation system towards professional skepticism and in firms with a high professional orientation. Last, we find that fraud brainstorming quality is somewhat different in our sample compared to fraud brainstorming quality observed in the US (see Brazel et al. 2010; Dennis and Johnstone 2016), especially regarding fraud brainstorming attendance and communication as the attendance rate and contribution of specialists is lower in our sample. We do not find important differences for professional skepticism traits with regard to fraud brainstorming structure and timing, and engagement team effort.

\subsection{LITERATURE REVIEW AND HYPOTHESIS}

Auditors are responsible for providing reasonable assurance that the financial statements of the client are free from material misstatements due to error or fraud (IFAC 2009b). Auditing standards therefore require a discussion among the engagement team members, at the beginning of the audit, to discuss the susceptibility of the client's financial statements to material misstatements due to fraud or error (IFAC, 2009b). Although the intention and the wording are the same, the ISA's do not specifically refer to this discussion as "brainstorming", contrary to SAS No. 99. The concept of brainstorming is commonly used in audit literature and audit practice where the brainstorming session includes identifying fraud risk, fraud risk assessment and planning the fraud risk responses (Hammersley 2011).

\section{Fraud Brainstorming Quality}

Prior research has investigated fraud brainstorming processes and outcomes and demonstrates that fraud brainstorming enables the identification of fraud risk factors and associated audit responses (Carpenter 2007; Hoffman and Zimbelman 2009; Lynch et al. 2009; Trotman et al. 2009; Chen et al. 2015). Brazel et al. (2010) developed a measure of fraud brainstorming quality, where quality is a function of attendance and communication, brainstorming 
structure and timing, and engagement team effort. They report descriptive statistics on the 21 items underlying fraud brainstorming quality. Dennis and Johnstone (2016) update and extend their insights with regard to fraud brainstorming quality and practices by not only reporting descriptive statistics on the underlying items of fraud brainstorming quality, but also on differences in audit team characteristics and brainstorming practices across risk and trading-status partitions.

In addition to the development of a fraud brainstorming quality measure, Brazel et al. (2010) also developed and tested a conceptual model that links fraud risk factors, fraud risk assessment, and fraud risk responses to fraud brainstorming quality. They found that fraud brainstorming quality moderates the relations between fraud risk factors and fraud risk assessments, and between fraud risk assessments and fraud-related testing. These results suggest that higher fraud brainstorming quality leads to better fraud risk identification and more effective audit plans to identify misstatements due to fraud. Yet, to deal with fraud that causes a material misstatement in the financial statements, ISA 240 not only requires a discussion among the engagement team member, but also the exercise of professional skepticism throughout the audit.

\section{Professional Skepticism}

Both regulators and standard setters (e.g., AFM 2014; IFIAR 2015; IAASB 2015, 2017; PCAOB 2015b) and academic literature (e.g., Glover and Prawitt 2014; Hurtt et al. 2013; Nelson 2009; Nolder and Kadous 2018) recognize the fundamental role of professional skepticism as an input to audit quality. When auditors apply more professional skepticism in their judgments and actions, the level of audit quality attained on audit engagements should increase. To better understand the link between an auditor's professional skepticism and audit quality, research has attempted to define and model professional skepticism.

The extant literature emphasizes three different definitions of professional skepticism. First, the neutral definition which states that the auditor neither assumes that management is dishonest nor assumes unquestioned honesty (O'Malley 2000) and which is referenced in numerous auditing standards. Second, the professional moral courage definition of professional skepticism, where auditors vary in their willingness to take skeptical actions (Hurtt et al. 2013). Last, the presumptive doubt definition which states that auditors present different levels of dispositional trust (McKnight et al. 2002; McKnight et al. 2004; Harding et al. 2016) and have relatively more doubt about the validity of an assertion than about its invalidity, assuming some level of management bias or dishonesty by management unless evidence indicates otherwise (Bell, Peecher, and Solomon 2005). This definition is consistent with fraud standards and under this view, skepticism is the opposite of trust (Shaub 1996). 
Different studies in prior literature have developed a model for professional skepticism (Nelson 2009; Hurtt et al. 2013; Glover and Prawitt 2014; Nolder and Kadous 2018). The general idea of those models is that professional skepticism arises as a consequence of the combination of individual characteristics including personality traits, knowledge, motivation, and social characteristics like firm culture, client pressure, and firm methodology.

Contrary to what one would expect, given the importance placed on the exercise of professional skepticism in fraud detection, little research to date has focused on this topic. Carpenter and Reimers (2013) investigated the importance of a partner's emphasis on skepticism (i.e., tone at the top) with respect to fraud risk identification, fraud risk assessment, and fraud risk responses. Based on an experiment with 80 managers from Big 4 firms, they found that audit partners who put more emphasis on skepticism cause audit managers to more effectively and efficiently identify fraud risk factors and choose relevant audit testing procedures. McAllister, Blay, and Kadous (2018) conducted an experiment with 267 accounting master students and found that including participants with a high professional skepticism in a group increases the group's perceived risk of fraud. These results suggest that there is a link between professional skepticism and fraud detection, but there is no evidence for the relationship between fraud brainstorming quality and professional skepticism, and more specifically professional skepticism traits. Fraud brainstorming is a planning stage activity which includes identifying fraud risk factors, fraud risk assessment and planning the associated fraud risk responses (Carpenter 2007, Hoffman and Zimbelman 2009; Lynch et al. 2009; Trotman et al. 2009;Hammersley 2011; Chen et al. 2015). In accordance with ISA 240, the fraud brainstorming session includes a discussion of the susceptibility of the financial statements to material misstatement due to fraud which provides the audit partner to share insights about fraud and enables the partner to consider appropriate fraud risk responses. ${ }^{29} \mathrm{~A}$ more skeptical engagement leader might discuss more extensively, which leads to a higher fraud brainstorming quality. However, as discussed above, in prior literature, professional skepticism is modelled as a combination of both individual and social characteristics (e.g., Nolder and Kadous 2018). Consequently, it is not evident that the individual professional skepticism traits have an impact on the audit process or outcome. Therefore, we control for both individual and social characteristics which together form an auditor's professional skepticism to enable us to make the distinction between the effect of professional skepticism traits and the effect of other characteristics of professional skepticism. We focus on professional skepticism

${ }^{29}$ In the Netherlands, the ISA's are adopted without modifications. Therefore, auditors are required to have a discussion among the engagement team regarding the risks of material misstatements due to fraud (i.e., a fraud brainstorming session) in accordance with ISA 240. 
traits as used in prior literature (e.g., Hurtt et al. 2013; Quadackers et al. 2014; Cohen et al. 2017) and formulate the following research question:

RQ1: To what extent do professional skepticism traits of the engagement partner affect fraud brainstorming quality?

Figure 3.1 illustrates our conceptual model. We expect a positive effect of professional skepticism traits on fraud brainstorming quality, while controlling for other individual characteristics (knowledge and experience), and social characteristics (tone at the top and time budget pressure).

\section{Professional Skepticism}

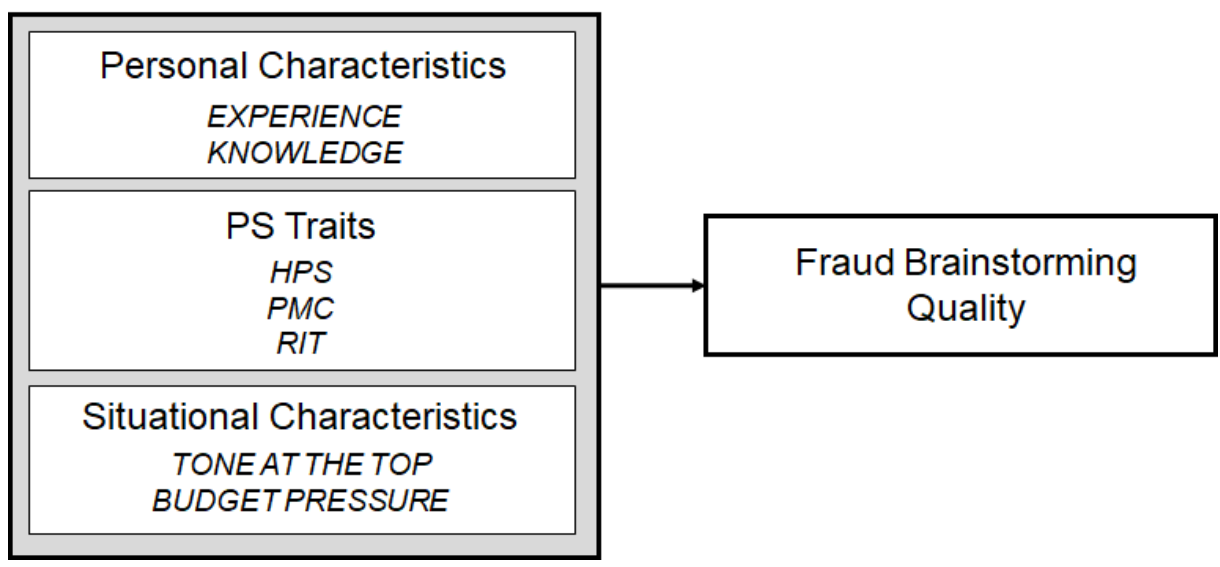

Figure 3.1 Conceptual model

\subsection{Methodology}

\section{Participants}

To investigate the effect of professional skepticism traits on fraud brainstorming quality, we combine survey and proprietary archival data which we obtained from five Dutch audit firms participating in our project: two Big 4 and three non-Big 4 audit firms. ${ }^{30}$ Each audit firm provided a selection of engagements (number depending on the size of the audit firm) and archival data related to those engagements. We selected a number of auditors to participate in our survey from the engagement teams of each of these engagements, based upon their personnel number, team role, and hours worked on the engagement. ${ }^{31}$

30 This study is part of a Foundation for Auditing Research (FAR) project: "Professional Skepticism Profiles, Effects on Audit Processes and Outcomes, and the Moderating Role of Audit Firm Culture". The FAR facilitated the delivery of data from the audit firms in the Netherlands to the research team.

31 For each engagement, we tried to select at least a partner, a manager, and a senior/staff. 
Table 3.1 details the construction of our sample. We received information from the Dutch audit firms for in total 342 engagements. For these engagements, we were able to select 312 partners to participate in our study. ${ }^{32}$ Invitations to participate in the study were sent via e-mail at the beginning of the year 2018 and up to four reminders were sent. ${ }^{33}$ We received 214 completed surveys, which represent a 68.6 percent response rate. This is a rather high response rate compared to response rates in other auditing surveys (e.g., 16 percent response rate by Nelson et al. (2002); 48.8 percent response rate by Brazel et al. (2010); see Nkansa and Bailey 2018). Due to missing data, we report statistics of fraud brainstorming quality based on 185 observations. Further, to investigate RQ1, we use a sample of 125 observations as a result of a loss of 60 observations due to missing data for auditor and client characteristics. ${ }^{34}$

Table 3.1 Sample Composition

\begin{tabular}{|c|c|c|c|c|c|c|c|}
\hline \multicolumn{8}{|c|}{ Panel A. Sample based on survey data } \\
\hline \multirow{3}{*}{$\begin{array}{l}\text { Selected engagements } \\
\text { Selected partners for } \\
\text { survey }\end{array}$} & Total & Firm 1 & Firm 2 & Firm 3 & Firm 4 & \multirow{2}{*}{$\underline{\text { Firm } 5}$} & \multirow{2}{*}{$\frac{\text { Firm } 6}{26}$} \\
\hline & $\overline{342}$ & 78 & 13 & $\overline{140}$ & $\overline{36}$ & & \\
\hline & 312 & 74 & 12 & 128 & 34 & 42 & 22 \\
\hline Respondents & 214 & 59 & 7 & 79 & 21 & 30 & 18 \\
\hline Response rate & $68.6 \%$ & $79.7 \%$ & $58.3 \%$ & $61.7 \%$ & $61.8 \%$ & \multirow{2}{*}{$\begin{array}{l}71.4 \% \\
(2)\end{array}$} & $81.8 \%$ \\
\hline Missing data & $(29)$ & $(10)$ & (3) & $(10)$ & $(2)$ & & (2) \\
\hline Final sample & 185 & 49 & 4 & 69 & 19 & 28 & 16 \\
\hline \multicolumn{8}{|c|}{ Panel B. Sample based on survey and archival data } \\
\hline \multicolumn{5}{|l|}{ Description } & & \multicolumn{2}{|c|}{$\underline{\text { Sample size }}$} \\
\hline \multicolumn{6}{|c|}{ Total observations based on the survey data } & \multicolumn{2}{|c|}{185} \\
\hline \multicolumn{6}{|c|}{ Less survey observations with no archival data } & \multicolumn{2}{|c|}{ (22) } \\
\hline \multicolumn{6}{|c|}{$\begin{array}{l}\text { Less observations with missing data for auditor and client } \\
\text { characteristics }\end{array}$} & \multicolumn{2}{|c|}{ (38) } \\
\hline \multicolumn{6}{|c|}{ Observations available for final sample } & \multicolumn{2}{|c|}{125} \\
\hline
\end{tabular}

32 We have multiple engagements with the same engagement partner in our sample, for which we were able to send only one survey per respondent. This resulted is the selection of 312 partners for 342 engagements.

33 Emails were sent via CenterData, an independent datacenter. All the data were delivered to CenterData, where the data were anonymized and transformed before they were delivered to our research team.

34 There are no systematic differences between the 125 observations in the final sample and the 60 lost observations; the differences in means for HPS, PMC and RIT are insignificant (respectively $p=0.312, p=0.990$, and $p=0.912$ ). 


\section{Instrument}

We constructed a survey which contained questions on the demographics of the auditor (e.g., experience, personality traits), the accounting firm (e.g., tone at the top, time budget pressure), a specific client (e.g., client importance, client experience), and the fraud brainstorming session of that specific client engagement (e.g., fraud brainstorming attendance, fraud brainstorming preparation). The auditors selected for participation in the survey received an invitation via mail indicating to which client the engagement-specific questions relate.

To measure the professional skepticism traits, we included the Hurtt Professional Skepticism Scale (Hurtt 2010), Rotter's Interpersonal Trust Scale (Wrightsman 1991) and Professional Moral Courage Scale (Sekerka et al. 2009). The score of an auditor on the Hurtt Professional Skepticism Scale is used to measure the neutral trait skepticism, with higher scores indicating higher neutral trait skepticism. The scale consists of 30 items scored on a 6-point Likert Scale, ranging from strongly disagree to strongly agree. The Hurtt Professional Skepticism Scale includes questions designed to assess whether an auditor has a questioning mind, is willing to suspend judgment, searches for knowledge, has interpersonal understanding, and has autonomy and self-esteem. ${ }^{35}$ The Professional Moral Courage Scale consists of 15 items that are scored on a 5-point Likert Scale, varying from almost never true to almost always true. Adding up the scores provides the professional moral courage score with higher scores indicating higher willingness to take skeptical actions. Moral courage explains why one actor acts in an ethical manner whereas another who faces the same ethical judgment in the same situation does not act in an ethical manner (Kidder 2005; Sekerka and Bagozzi 2007; Khelil, Hussainey, and Noubbigh 2016). The scale is intended to assess five dimensions: moral agency, multiple values, endurance of threats, going beyond compliance, and moral goals. ${ }^{36}$ The score of the auditor on Rotter's Interpersonal Trust Scale provides the interpersonal trust score with higher scores indicating higher interpersonal trust. The scale consists of 25 items that are scored on a 5-point Likert Scale, varying from strongly disagree to strongly agree. The Rotter Interpersonal Trust Scale (RIT) is intended to capture 'a generalized expectancy held by an individual or a group that the word, promise, verbal or written statement of another individual or group can be relied upon' (Rotter 1967, p. 651). We use the reversed of the score on the RIT to measure the presumptive doubt trait skepticism. ${ }^{37}$

35 Example of questions: 'I often accept other peoples' explanations without further thought.'; 'I often reject statements unless I have proof that they are true.'

36 Example of questions: 'I am the type of person who uses a guiding set of principles from the organization when I make ethical decisions on the job.'; 'I act morally even if it puts me in an uncomfortable position with my superiors.'

37 Example of questions: 'In dealing with strangers one is better off to be cautious until they have provided evidence that they are trustworthy.'; 'Most experts can be relied upon to tell the truth about the limits of their knowledge.' 
Descriptive statistics regarding the measures of professional skepticism traits are shown in Table 3.2. The mean score for HPS, PMC and RIT is respectively $141.33,84.85$, and 75.13 . These results are similar to the results of Quadackers et al. (2014), who also use absolute scores of the scales, and Cohen et al. (2017), who use the average scores of the scales (the absolute score divided by the number of questions). Further, the Cronbach's alpha values for the scales are acceptable, 0.83 for the Hurtt Professional Skepticism Scale, 0.91 for the Professional Moral Courage Scale and 0.79 for Rotter's Interpersonal Trust Scale, which is also similar to the results of Quadackers et al. (2014).

Table 3.2 Descriptive Statistics for the Scales Measuring Professional Skepticism

\begin{tabular}{lcccccc}
\hline Measurement scale & Mean & $\begin{array}{c}\text { Standard } \\
\text { deviation }\end{array}$ & $\begin{array}{c}\text { Theoretical } \\
\text { range }\end{array}$ & $\begin{array}{c}\text { Actual } \\
\text { range }\end{array}$ & $\begin{array}{c}\text { Theoretical } \\
\text { midpoint }\end{array}$ & $\begin{array}{c}\text { Cronbach's } \\
\text { alpha }\end{array}$ \\
\hline$H P S$ & 141.33 & 9.72 & $30-180$ & $114-165$ & 105 & 0.83 \\
$P M C$ & 83.85 & 10.26 & $15-105$ & $60-105$ & 60 & 0.91 \\
$R I T^{*(\mathrm{R})}$ & 75.13 & 8.96 & $25-125$ & $54-111$ & 75 & 0.79
\end{tabular}

This table summarizes the descriptive statistics for the professional skepticism measures. A total of 185 observations are used to calculate the descriptive statistics. See Appendix II for variables definitions.

*(R) We use the reverse of the score of the auditor on The Rotter Interpersonal Trust Scale to measure RIT, to capture distrust, a professional skepticism trait.

\section{Research Design}

To examine RQ1, we estimate the following OLS regression model ${ }^{38}$ :

$$
\begin{aligned}
F B Q= & \beta_{1}+\beta_{2} \text { HPS }+\beta_{3} \text { PMC }+\beta_{4} R I T+\beta_{5} \text { FRAUDEXP }+\beta_{6} \text { MATMISEXP_cat }+ \\
& \beta_{7} \text { AUDITEXP_Cat }+\beta_{8} \text { CLIENTEXP }+\beta_{9} \text { TEAMEXP }+\beta_{10} \text { TONE_AT_TOP }+ \\
& \beta_{11} \text { BUDGETPRESSURE }+\beta_{12} \text { TEAMSIZE }+\beta_{13} \text { FRAUDDETECT }+ \\
& \beta_{14} \text { MATMISDETECT }+\beta_{15} \text { CLIENTIMPORTANCE }+\beta_{16} \text { MANAGERCHANGE + } \\
& \beta_{17} \text { SENIORCHANGE }+\beta_{18} \text { OPENDISC + } \beta_{19} \text { ROUNDROBIN + } \beta_{20} \text { NOMINAL + } \\
& \beta_{21} \text { INDUSTRY }+\beta_{22} \text { FIRM it }+\varepsilon_{i t}
\end{aligned}
$$

Where $F B Q$ is the fraud brainstorming quality measured using the Brazel et al. (2010) 21-item validated scale (see Appendix II for variable definitions). HPS, PMC and RIT are our variables of interest measuring trait skepticism. These are respectively the score of an auditor on the Hurtt Professional Skepticism Scale, Professional Moral Courage Scale, and the reversed Rotter Interpersonal Trust Scale. Further, we include other individual and situational characteristics

38 As the dependent variable in our model, $F B Q$, is not a continuous variable, we perform a robustness check by estimating the relationship following a Poisson model. The result are very similar. 
which, together with the professional skepticism traits, form an auditor's professional skepticism. We capture the auditor's knowledge and experience by including the variables FRAUDEXP, MATMISEXP_cat, AUDITEXP_cat, and CLIENTEXP. The variables FRAUDEXP and MATMISEXP_cat measure the number of prior engagements the participant served on in which fraudulent financial reporting/material misappropriation of assets was identified. The number of years of audit experience is measure by AUDITEXP_cat. CLIENTEXP measures the client tenure as a partner, more specifically the number of years served as an engagement leader for this client. To take into account situational factors, we include TEAMEXP, TONE_AT_TOP, and BUDGETPRESSURE. TEAMEXP measures the perception of the engagement leader of the entire engagement team's level of expertise on this client on a scale from 1 to 7 (Dennis and Johnstone 2016). We use the reversed score of the measure of Sweeney et al. (2010) of perceived unethical tone at the top to measure TONE_AT_TOP. A proper tone at the top is important to the success of the brainstorming session (Beasley and Jenkins 2003; Landis, Jerris, and Braswell 2008). BUDGETPRESSURE measures the perceived time budget pressure on a scale from 1 to 7 . Consistent with prior literature, we include control variables which have been shown to be related to fraud detection and fraud brainstorming. Specifically, TEAMSIZE, which is the audit team size, is included to capture client complexity and client size as these are primary factors for labor on an audit engagement (Causholli, De Maritinis, Hay, and Knechel 2010); FRAUDDETECT and MATMISDETECT, which are dichotomous variables equal to 1 if fraudulent financial reporting/material misappropriation of assets has been detected at the client during the past three years; CLIENTIMPORTANCE, which measures the importance of a client on a scale from 1 to 7; and MANAGERCHANGE and SENIORCHANGE measure whether the lead engagement manager/senior has changed from the prior year. If the lead manager/senior did not change, he/she has more client-specific experience (Dennis and Johnstone 2016). Next, the variables capturing the nature of the format of the discussion OPENDISC, ROUNDROBIN, and NOMINAL, which measure respectively whether the discussion was open (i.e., brainstorming in an unstructured manner), round robin (i.e., brainstorming in a relatively structured manner by taking turns presenting ideas), or nominal (i.e., developing a list of ideas based on auditors' individual lists with no discussion with other engagement team members), are included. Previous research has shown that brainstorming effectiveness depends on the nature of the format of the discussion (Beasley and Jenkins 2003; Carpenter 2007; Chen et al. 2015; Landis et al. 2008). Finally, we include industry and audit firm fixed effects, and all regressions are based on robust standard errors. 


\subsection{RESULTS}

\section{Descriptive Statistics Fraud Brainstorming Quality and Underlying Items}

First, we investigate both the total fraud brainstorming quality and the underlying items compared to fraud brainstorming quality as reported by Brazel et al. (2010) and Dennis and Johnstone (2016) and across our partitions of professional skepticism traits to see whether fraud brainstorming quality is different between high versus low trait skepticism. We classify observations with above (below) median HPS, PMC and RIT as "high" ("low") trait skepticism and perform two-samples $t$-tests. ${ }^{39}$ Table 3.3 presents the relevant descriptive statistics.

The mean $F B Q$ in the overall sample is 11.6 , with a range from 5 to 20 . Compared to Brazel et al. (2010) and Dennis and Johnstone (2016), our mean is a little higher (means of 10.56 and 10.83, respectively). The minimum and maximum $F B Q$ scores in our sample are also higher compared to Brazel et al. (2010) and Dennis and Johnstone (2016) (ranges of 3-18 and 2-18, respectively). With respect to the difference between high and low trait skepticism, we find that partners with a high neutral trait (HPS) and high moral courage (PMC) report significant higher fraud brainstorming quality. Meanwhile, partners with a high presumptive doubt trait skepticism $(R I T)$ report significant lower fraud brainstorming quality. The 21 underlying items of $F B Q$ are based on three elements: attendance and communication, brainstorming structure and timing, and engagement team effort.

\section{Attendance and Communication}

With regard to attendance and communication, the results show that for 81 percent of the engagements, the partner or a forensic specialist led the session. All levels of the engagement team attended the session in 96 percent of the cases, while the attendance of a forensic, IT and tax specialist is much lower, in respectively 5, 39, and 21 percent of the sessions. Compared to the attendance reported by Brazel et al. (2010) and Dennis and Johnstone (2016), the attendance of the partner and other levels of the engagement team is higher in our sample, but the attendance of forensic, IT and tax specialists is much lower in our sample. Further, we find that partners indicate an average contribution of staff (4.5) and a slightly above average to high contribution of other team members $(5.32-5.89)$ to the brainstorming session. On the other hand, they indicate

39 Dichotomizing variables relating to individual differences is rather common in accounting research (e.g., Gissel and Johnstone 2017; Quadackers et al. 2014). Previous research does not document a scale score that is indicative of high levels of trait PS, although it is common practice to use the median as cut point. However, we acknowledge that this is somewhat arbitrary. The convention from psychology is to consider everything that is within $0.5 \mathrm{SD}$ of the mean as "average" (and lower scores as "low" and higher scores as "high"), however this is also criticized (Johnson 2019). Our results are very similar when using 0.5 SD above the mean as cut point. 
a slightly below average contribution of forensic specialists (3.02). The results reported in Brazel et al. (2010) show a lower contribution of staff (3) and seniors (4.2) and a higher contribution of forensic specialists (4.9) compared to our sample. Last, the team members indicate a high level of openness to ideas from the partners in our sample. These results are similar to the results of Brazel et al. (2010) and Dennis and Johnstone (2016).

Table 3.3 Fraud Brainstorming Quality and Underlying Items

\begin{tabular}{|c|c|c|c|c|c|c|c|c|c|c|}
\hline \multirow[t]{3}{*}{ Item ${ }^{a}$} & \multicolumn{4}{|c|}{ Overall $[n=185]$} & \multicolumn{2}{|c|}{$\begin{array}{c}\text { High }[n=91] \\
\text { versus } \\
\text { Low }[n=94] \\
\text { HPS }\end{array}$} & \multicolumn{2}{|c|}{$\begin{array}{c}\text { High }[\mathrm{n}=88] \\
\text { versus } \\
\text { Low }[\mathrm{n}=97] \\
P M C \\
\end{array}$} & \multicolumn{2}{|c|}{$\begin{array}{c}\text { High }[\mathrm{n}=85] \\
\text { versus } \\
\text { Low }[\mathrm{n}=100] \\
\text { RIT }\end{array}$} \\
\hline & \multicolumn{2}{|c|}{$\%$} & \multicolumn{2}{|c|}{ \# } & & & & & & \\
\hline & Me. & $\underline{\text { Std. }}$ & Me. & $\underline{\text { Std. }}$ & $\underline{\Delta}^{\mathrm{b}}$ & $\underline{\text { Stat. }}$ & $\underline{\Delta}^{\mathrm{b}}$ & $\underline{\text { Stat. }}$ & $\underline{\Delta}^{\mathrm{b}}$ & $\underline{\text { Stat. }}$ \\
\hline$F B Q$ & 11.6 & 2.8 & & & 1.20 & $2.95^{\star \star \star}$ & 1.59 & $3.98^{* \star *}$ & $(.87)$ & $2.11^{*+*}$ \\
\hline \multicolumn{11}{|c|}{ Attendance and Communication } \\
\hline LEADER_PTR_FS & .81 & .39 & & & $(.06)$ & 1.04 & .01 & 24 & .00 & .03 \\
\hline$A T T \_A L L \_L V L S$ & .96 & .20 & & & .00 & .05 & .00 & .14 & .01 & .49 \\
\hline ATT_FORENSIC & .05 & .22 & & & .03 & 1.07 & .06 & $1.87^{\star *}$ & .00 & .09 \\
\hline ATT_IT & .39 & .49 & & & .14 & $2.00^{\star \star}$ & .10 & $1.43^{\star}$ & $(.05)$ & .63 \\
\hline ATT_TAX & .21 & .41 & & & .11 & $1.94^{\star \star}$ & .17 & $2.94^{\star \star \star}$ & $(.10)$ & $1.63^{*}$ \\
\hline CONTR_STAFF & & & 4.50 & 1.11 & .43 & $2.50^{\star \star \star}$ & .41 & $2.43^{\star \star *}$ & $(.18)$ & 1.06 \\
\hline CONTR_SENIOR & & & 5.32 & 1.24 & .25 & 1.11 & .42 & $1.93^{* *}$ & $(.13)$ & .58 \\
\hline CONTR_MAN & & & 5.89 & .82 & .34 & $2.80^{* \star *}$ & .50 & $4.21^{\star \star *}$ & $(.08)$ & .62 \\
\hline CONTR_PTR & & & 5.79 & .80 & .27 & $2.26^{\star \star *}$ & .45 & $3.82^{* \star \star}$ & (.17) & $1.43^{*}$ \\
\hline CONTR_FOREN & & & 3.02 & 2.38 & 1.24 & $1.76^{\star *}$ & 1.59 & $2.27^{\star \star \star}$ & (1.2) & $1.75^{* *}$ \\
\hline PTR_OPEN & & & 5.09 & 1.05 & $(.12)$ & .61 & .21 & 1.03 & .08 & .38 \\
\hline \multicolumn{11}{|l|}{ Structure and Timing } \\
\hline AGENDA & .88 & .32 & & & .04 & .82 & .03 & .66 & $(.04)$ & .86 \\
\hline NO_CHECKLIST & .37 & .48 & & & $(.02)$ & .28 & (.13) & $1.77^{* *}$ & $(.04)$ & .52 \\
\hline TIMING_PPEP & .68 & .47 & & & .01 & .17 & .03 & .50 & .01 & .21 \\
\hline TIMING_END_PY & .15 & .36 & & & .07 & $1.32^{*}$ & .01 & .28 & .13 & $2.44^{*+*}$ \\
\hline \multicolumn{11}{|c|}{ Engagement Team Effort } \\
\hline HOURS_PREP & & & 6.26 & .83 & 1.46 & 1.11 & 2.08 & $1.59^{\star *}$ & $(.37)$ & .28 \\
\hline SESSIONS_MULT & .46 & .50 & & & .06 & .79 & .07 & .91 & $(.10)$ & $1.33^{*}$ \\
\hline SESSIONS_DUR & & & 66 & 195 & 10 & .34 & 53 & $1.79^{* * *}$ & 23 & .77 \\
\hline LIST_PRIOR & .57 & .50 & & & .07 & .99 & .17 & $2.42^{\star \star \star}$ & $(.09)$ & $1.26^{*}$ \\
\hline DISCUUSS_MGT & & & 4.49 & .83 & .20 & $1.58^{\star \star}$ & .24 & $1.86^{\star \star}$ & (.03) & .28 \\
\hline DISCUSS_RESP & & & 4.48 & .85 & .10 & .72 & .26 & $2.01^{\star *}$ & $(.09)$ & .66 \\
\hline \multicolumn{11}{|c|}{$\begin{array}{l}\text { This table reports the overall mean and standard deviation and the difference in means [difference } \Delta=\text { mean High } \\
- \text { mean Low] of the measure of fraud brainstorming quality and the underlying items for the different professional } \\
\text { skepticism measures, and the absolute t-statistic. } \\
\text { across more than one professional skepticism measure. } \\
\text { a See Appendix II for variables definitions. Observations with above (below) mean HPS, PMC and RIT are classified } \\
\text { as "High" ("Low"). } \\
\text { b Differences in parentheses indicate the mean of the respective variable is lower in the respective high HPS, PMC } \\
\text { and RIT sample partition. }\end{array}$} \\
\hline
\end{tabular}


Regarding the difference between high and low trait skepticism, the results show that there is a significant difference between the attendance and contribution to the session of a partner with high neutral trait and high moral courage compared to the attendance and contribution to the session of a partner with low neutral trait and low moral courage. More specifically, there is a significantly higher attendance rate of specialists and a higher contribution of all team members, especially forensic specialists. Again, we find opposite results for partners with a high presumptive doubt trait with lower attendance rates and lower contribution.

\section{Brainstorming Structure and Timing}

For the brainstorming structure and timing, we observe, in the overall sample, that an agenda was used 88 percent of the time and a checklist was used 37 percent of the time. The use of an agenda in our sample is similar to Brazel et al. (2010) and Dennis and Johnstone (2016), whereas the use of checklists in our sample is higher compared to their samples. Next, with respect to timing, we find that fraud brainstorming sessions were held at the end of the prior year audit for 15 percent of the engagements and during pre-planning or early in planning for 68 percent of the engagements. Brazel et al. (2010) report that 16 percent (65 percent) of the engagements in their sample held a session at the end of the prior year audit (during pre-planning or early in planning) which is similar to our sample. We do not observe many significant differences with respect to brainstorming structure and timing when comparing high and low trait skepticism. We only find that engagement leaders with high trait skepticism more frequently plan a session at the end of prior year audit.

\section{Engagement Team Effort}

With regard to engagement team effort, the results show that on average 6 hours are spent by the engagement team preparing for the session and the average length of a session is 66 minutes. The preparation and duration of the sessions in our sample is lower (higher) compared the preparation and duration reported by Brazel et al. (2010) (Dennis and Johnstone 2016). Further, 46 (57) percent of the engagement teams held multiple sessions (developed a list of fraud risks prior to brainstorming) which is similar to Brazel et al. (2010). Last, the engagement leaders in our sample report a moderate to high amount of discussion about how management might perpetrate fraud and about audit responses to fraud risk, which is similar to Brazel et al. (2010). With respect to the difference between high and low trait skepticism, the results show that especially engagement leaders with high moral courage report a higher engagement team effort with a significantly longer preparation of the session, longer session, higher amount of discussion and significantly more use of a list of identified fraud prior to the session. 
In sum, we observe that fraud brainstorming quality is somewhat different in our sample compared to fraud brainstorming quality observed in the US, especially regarding fraud brainstorming attendance and communication. More specifically, the attendance rate and contribution of specialists is lower in our sample. With regard to structure and timing, and engagement team effort, we do not observe big differences.

Regarding the difference between high and low trait skepticism, we specifically find that there is a significantly higher attendance rate and contribution of specialists, and a higher extent of discussion about how management might perpetrate fraud for sessions of partners with high neutral trait skepticism and high moral courage. Further, partners with high moral courage make less use of checklists, take more time preparing the session, have longer fraud brainstorming sessions, more often ask team members to identify risk prior to the session, and have a more extensive discussion about audit responses to fraud risk. We find opposite results for partners with a high presumptive doubt trait with lower attendance rates and lower contribution and no list of identified risks prior to the session.

\section{Descriptive Statistics Control Variables}

To examine RQ1, we combine the survey data with archival data. Table 3.4 provides the descriptive statistics regarding the variables in our regression model. With regard to experience, the results show that the engagement leaders in our sample on average have served on six engagements in which fraudulent financial reporting was identified. Further, they on average served on one to two engagements in which material misappropriation of assets was identified. The mean audit experience in general is 3.85 (coded 1-4), indicating that partners have 11-15 years of audit experience in general. The engagement partner served on average one to three years for this client, resulting in a mean CLIENTEXP of 2.26 (coded 1-3). The auditors in our sample are slightly more experienced than the auditors in the sample of Brazel et al. (2010) and Dennis and Johnstone (2016), however the reported client experience is similar. The engagement leaders perceive the level of expertise of the entire engagement team on this specific client as moderate to high, which is similar to Brazel et al. (2010) and Dennis and Johnstone (2016). The perceived ethical tone at the top is relatively high (5.7 on a scale of $1=$ low to $7=$ high) and time budget pressure is relatively low (3.2 on a scale of $1=$ low to $7=$ high). The clients in the sample are not very complex with a mean score of 1.58 (coded 1-5), which indicates an average team size of six to ten auditors. The number of engagements in our sample where fraudulent financial reporting (material misappropriation of assets) has been detected at the client during the past three years is small. Only in five (eight) percent of the engagements was fraud detected recently, 
which is similar to Dennis and Johnstone (2016) but lower than the analogous means of 24 percent in Brazel et al. (2010). 27 percent of the engagements had a change of lead engagement manager/senior compared to the prior year. Dennis and Johnstone (2016) reported a similar manager turnover (34 percent) but a greater transition at the senior auditor level (54 percent). Regarding the format of discussion, we find that open discussion is still the predominant format (86 percent of the engagements), which is similar to Brazel et al. (2010) and Dennis and Johnstone (2016). Round robin (25 percent of the engagements) and nominal group (3 percent of the engagements) are less frequently used..$^{40}$ Last, untabulated results show that the largest industy respresentations are financial services (28 percent) which is similar to Dennis and Johnstone (2016) but different from Brazel et al. (2010) with respectively 29 and 7 percent.

Table 3.4 Descriptive Statistics

\begin{tabular}{|c|c|c|c|c|c|c|}
\hline$\underline{\text { Variable }}$ & Mean & $\underline{\text { Median }}$ & Std. Dev & $\underline{\text { Min }}$ & $\underline{\text { Max }}$ & $\begin{array}{c}\text { Theoretical } \\
\text { range }\end{array}$ \\
\hline HPS & 140.83 & 141 & 9.08 & 119 & 165 & $30-180$ \\
\hline$P M C$ & 83.85 & 85 & 10.16 & 60 & 105 & $15-105$ \\
\hline$R I T$ & 75.08 & 75 & 8.93 & 54 & 105 & $25-125$ \\
\hline$F B Q$ & 12 & 12 & 2.99 & 6 & 20 & $0-21$ \\
\hline FRAUDEXP & 5.62 & 3 & 9.18 & 0 & 80 & \\
\hline MATMISEXP_cat & 2.42 & 3 & 0.76 & 1 & 3 & \\
\hline AUDITEXP_cat & 3.85 & 4 & 0.48 & 1 & 4 & \\
\hline CLIENTEXP & 2.26 & 2 & 0.65 & 1 & 3 & \\
\hline TEAMEXP & 4.94 & 5 & 0.77 & 3 & 7 & $1-7$ \\
\hline TONE_AT_TOP & 22.71 & 23 & 3.90 & 12 & 28 & $4-28$ \\
\hline BUDGETPRESSURE & 9.55 & 9 & 3.09 & 3 & 19 & $3-21$ \\
\hline TEAMSIZE & 1.58 & 1 & 0.91 & 1 & 5 & \\
\hline FRAUDDETECT & .05 & 0 & 0.21 & 0 & 1 & \\
\hline MATMISDETECT & .08 & 0 & 0.27 & 0 & 1 & \\
\hline CLIENTIMPORTANCE & 4.10 & 4 & 1.50 & 1 & 7 & $1-7$ \\
\hline MANAGERCHANGE & .27 & 0 & 0.45 & 0 & 1 & \\
\hline SENIORCHANGE & .27 & 0 & 0.45 & 0 & 1 & \\
\hline OPENDISC & .86 & 1 & 0.35 & 0 & 1 & \\
\hline ROUNDROBIN & .25 & 0 & 0.43 & 0 & 1 & \\
\hline NOMINAL & .03 & 0 & 0.15 & 0 & 1 & \\
\hline
\end{tabular}

40 More than one format could be used during the same engagement, so these numbers do not necessarily need to add to $100 \%$. 


\begin{tabular}{|c|c|c|c|c|c|c|c|c|c|c|c|c|c|}
\hline & $\begin{array}{c}0 \\
\mathbb{1} \\
\end{array}$ & $\begin{array}{l}w \\
\frac{0}{1}\end{array}$ & $\sum_{\Sigma}^{O}$ & $\stackrel{\hbar}{\boldsymbol{x}}$ & $\begin{array}{l}\frac{0}{x} \\
\text { 岁 } \\
\stackrel{0}{0} \\
\frac{\mathbb{1}}{1}\end{array}$ & 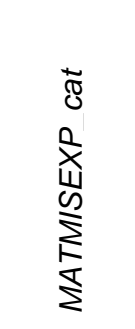 & 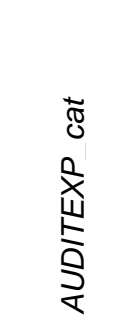 & 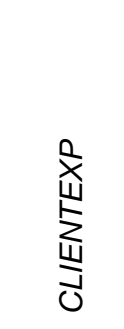 & 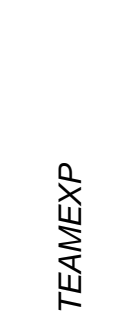 & 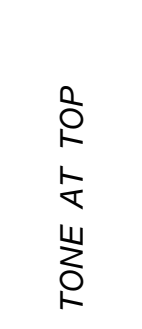 & 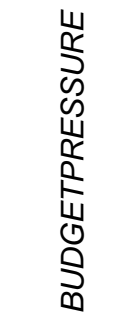 & $\frac{W}{N}$ & VIF \\
\hline HPS & $.3159^{*}$ & & & & & & & & & & & & 1.56 \\
\hline$P M C$ & $.4063^{*}$ & $.4613^{*}$ & & & & & & & & & & & 2.05 \\
\hline$R I T$ & -.1142 & .0082 & $-.1543^{*}$ & & & & & & & & & & 1.47 \\
\hline FRAUDEXP & .1222 & .0779 & .0241 & .0971 & & & & & & & & & 1.39 \\
\hline MATMISEXP_cat & -.0318 & .1255 & -.0046 & -.0327 & .0724 & & & & & & & & 1.40 \\
\hline AUDITEXP_cat & .0623 & .1551 & $.2024^{*}$ & -.0072 & .1231 & .1087 & & & & & & & 3.53 \\
\hline CLIENTEXP & .0500 & .0094 & .1291 & -.1320 & .0113 & .1419 & .1537 & & & & & & 1.43 \\
\hline TEAMEXP & $.3170^{*}$ & .2689 & .3752 & -.1516 & -.0398 & -.0012 & .0207 & .0292 & & & & & 2.01 \\
\hline TONE_AT_TOP & .1224 & .1483 & $.2300^{*}$ & -.0168 & $-.1711^{*}$ & -.0347 & .0734 & .0079 & .1556 & & & & 1.67 \\
\hline BUDGETPRESSURE & .0366 & -.0852 & -.0866 & $-.2108^{*}$ & -.0875 & -.0682 & -.1018 & -.0465 & -.1011 & $-.2163^{*}$ & & & 1.72 \\
\hline TEAMSIZE & $.3352^{*}$ & $.2000^{\star}$ & .1014 & $.1944^{*}$ & -.1460 & .0771 & -.0169 & -.0232 & $.1866^{*}$ & .1375 & .0688 & & 2.04 \\
\hline FRAUDDETECT & .1130 & .0373 & .0830 & -.0462 & -.0397 & .1232 & -.0069 & .0270 & .0656 & -.0509 & .0329 & $.2273^{*}$ & 1.78 \\
\hline MATMISDETECT & .0990 & .0558 & -.0495 & -.0591 & -.0457 & $.1876^{\star}$ & -.0920 & -.0715 & -.0944 & -.0542 & .1294 & $.2333^{*}$ & 2.25 \\
\hline CLIENTIMPORTANCE & $.3386^{*}$ & .1442 & .1319 & -.1332 & -.0499 & -.0593 & -.0795 & -.0778 & $.2164^{*}$ & -.0202 & $.2594^{*}$ & $.3346^{\star}$ & 1.79 \\
\hline MANAGERCHANGE & .0724 & .0980 & $.2007^{*}$ & -.0840 & -.1061 & .0675 & -.0315 & .0920 & -.0023 & .1327 & $.2122^{*}$ & .0426 & 1.67 \\
\hline SENIORCHANGE & $.2232^{*}$ & $.1816^{*}$ & .1197 & -.0589 & .1279 & .0202 & -.0315 & -.0755 & .0213 & .0032 & $.2385^{\star}$ & $.2015^{\star}$ & 1.86 \\
\hline OPENDISC & -.0459 & -.1112 & -.0950 & .0587 & .1199 & .0446 & .0127 & .0923 & -.1497 & -.1258 & -.0439 & .0381 & 1.85 \\
\hline ROUNDROBIN & $.1741^{*}$ & .1037 & .0786 & .0952 & -.0752 & -.0462 & .0278 & -.1420 & .0422 & .1342 & .0091 & .0183 & 1.99 \\
\hline NOMINAL & $.2631^{*}$ & -.0032 & .0074 & -.0894 & -.0220 & -.0170 & .0503 & .1000 & .0115 & .1190 & -.0109 & -.1012 & 1.33 \\
\hline & & & & & & & & & & & \multicolumn{3}{|c|}{ (continued on next page) } \\
\hline
\end{tabular}




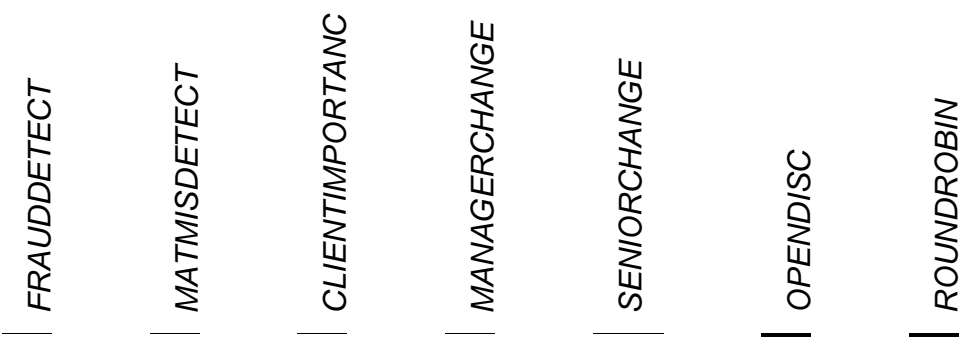

$\begin{array}{lrlllllll}\text { MATMISDETECT } & .4856^{*} & & & & & \\ \text { CLIENTIMPORTANCE } & .1601 & .1179 & & & & \\ \text { MANAGERCHANGE } & -.0532 & .0186 & .2469^{*} & & & \\ \text { SENIORCHANGE } & .1151 & .2174^{\star} & .2469^{*} & .3132^{*} & & \\ \text { OPENDISC } & -.1211 & .0370 & -.0478 & -.1589 & -.1589 & & \\ \text { ROUNDROBIN } & .0444 & .0355 & .0594 & .1902^{*} & .3567^{*} & -.5559^{*} & \\ \text { NOMINAL } & -.0352 & -.0462 & .1293 & -.0959 & -.0959 & .0643 & .0310\end{array}$

This table presents the correlation matrix. ${ }^{*}$ significant at .05 level. See Appendix II for variables definitions. 


\section{Correlation Matrix}

Table 5 reports the correlation matrix with significance levels reported at the 0.05 level. The correlation between HPS and RIT, HPS and PMC, and PMC and RIT is respectively $0.008(p=$ $.928), 0.461(p=0.000)$, and $-0.154(p=0.086)$. These results indicate that the three professional skepticism traits represent separate constructs. ${ }^{41}$ Further, HPS and PMC are moderately positively correlated with $F B Q$. The correlations between the other variables are small and the Variance Inflation Factors (VIF) do not exceed 3.53 which suggests that multicollinearity is not a concern.

\section{Regression Results}

To investigate RQ1, we estimate the regression model. Table 3.6 presents the results for RQ1. We observe that both neutral trait skepticism and moral courage are predictive of fraud brainstorming quality as HPS and $P M C$ are significantly positively associated with $F B Q$. Further, the results show that the variables TEAMEXP, TEAMSIZE, CLIENTIMPORTANCE, and NOMINAL are significantly positively associated with $F B Q$ indicating that also the experience of the engagement team, the size, complexity and importance of the client, and the format of the discussion have an effect on fraud brainstorming quality. We also run the regression including all measures of professional skepticism traits in the same model and observe that the PMC scale dominates the HPS scale in predicting fraud brainstorming quality. These results indicate that especially high professional moral courage of the partner has a positive effect on fraud brainstorming quality.

\subsection{ADDITIONAL ANALYSES}

First, we investigate how professional skepticism affects fraud brainstorming quality. To this end, we rerun the regressions with the three elements of fraud brainstorming quality as dependent variables and professional skepticism traits as variables of interest, while controlling for individual characteristics and social factors. Table 7 presents the results of these analyses. These results indicate that a high neutral trait skepticism, and, especially, a high moral courage of the partner has a positive significant impact on the attendance and communication in fraud brainstorming. We do not find a significant effect of professional skepticism traits on fraud brainstorming structure and timing, or on engagement team effort. These results are in line with the results of the two samples $t$-tests.

\footnotetext{
${ }^{41}$ This is also confirmed by a factor analysis.
} 
Table 3.6 Regression Results

\begin{tabular}{|c|c|c|c|c|c|c|c|c|}
\hline Independent Variable & $\begin{array}{l}\text { HPS } \\
\text { only }\end{array}$ & & $\begin{array}{l}P M C \\
\text { only }\end{array}$ & & $\begin{array}{l}R I T \\
\text { only }\end{array}$ & & $\begin{array}{c}\text { Full } \\
\text { model }\end{array}$ & \\
\hline & {$[1.771$} & & & & & & {$[0.88]$} & \\
\hline$P M C$ & & & .098 & *** & & & .083 & $* * *$ \\
\hline & & & [3.28] & & & & [2.55] & \\
\hline$R I T$ & & & & & -.049 & & -.038 & \\
\hline & & & & & {$[-1.56]$} & & {$[-1.28]$} & \\
\hline FRAUDEXP & .062 & & .062 & & .075 & * & .063 & * \\
\hline & {$[1.57]$} & & {$[1.65]$} & & [1.90] & & [1.75] & \\
\hline MATMISEXP_cat & -.194 & & -.115 & & -.157 & & -.150 & \\
\hline & {$[-0.69]$} & & {$[-0.37]$} & & {$[-0.52]$} & & {$[-0.49]$} & \\
\hline AUDITEXP_cat & -.175 & & -.272 & & .024 & & -.300 & \\
\hline & {$[-0.32]$} & & {$[-0.50]$} & & {$[0.04]$} & & {$[-0.57]$} & \\
\hline CLIENTEXP & .067 & & -.052 & & -.098 & & -.121 & \\
\hline & {$[0.16]$} & & {$[-0.13]$} & & {$[-0.22]$} & & {$[-0.30]$} & \\
\hline TEAMEXP & .723 & ** & .378 & & .784 & ** & .267 & \\
\hline & [2.07] & & [1.04] & & [2.27] & & {$[0.75]$} & \\
\hline$T O N E \_A T \_T O P$ & .062 & & .039 & & .060 & & .032 & \\
\hline & {$[0.96]$} & & [0.65] & & [0.94] & & {$[0.54]$} & \\
\hline BUDGETPRESSURE & -.036 & & -.028 & & -.068 & & -.042 & \\
\hline & {$[-0.47]$} & & {$[-.37]$} & & {$[-0.87]$} & & {$[-0.58]$} & \\
\hline TEAMSIZE & .738 & ** & .869 & $* * *$ & .995 & *** & .956 & $* * *$ \\
\hline & [2.24] & & [2.79] & & [2.71] & & [3.21] & \\
\hline FRAUDDETECT & -.130 & & -.789 & & -.015 & & -.586 & \\
\hline & {$[-0.09]$} & & {$[-0.59]$} & & {$[-0.01]$} & & {$[-0.48]$} & \\
\hline MATMISDETECT & 1.017 & & 1.299 & & .757 & & .945 & \\
\hline & [0.59] & & {$[0.81]$} & & [0.42] & & [0.64] & \\
\hline CLIENTIMPORTANCE & .393 & ** & .412 & ** & .337 & ** & .370 & ** \\
\hline & [2.23] & & [2.44] & & [1.88] & & [2.10] & \\
\hline MANAGERCHANGE & .302 & & .087 & & .450 & & .146 & \\
\hline & {$[0.46]$} & & {$[0.14]$} & & {$[0.70]$} & & {$[0.25]$} & \\
\hline SENIORCHANGE & .126 & & .063 & & .097 & & -.044 & \\
\hline & {$[0.18]$} & & [0.09] & & {$[0.13]$} & & {$[-0.07]$} & \\
\hline OPENDISC & .659 & & .376 & & .692 & & .521 & \\
\hline & {$[1.00]$} & & [0.55] & & [1.12] & & {$[0.75]$} & \\
\hline ROUNDROBIN & .909 & & .916 & & 1.038 & * & 1.056 & * \\
\hline & [1.55] & & [1.56] & & [1.73] & & [1.80] & \\
\hline NOMINAL & 3.514 & *** & 4.024 & $* *$ & 3.470 & *** & 3.879 & $* * *$ \\
\hline & [4.01] & & [4.92] & & [4.04] & & [4.91] & \\
\hline IND_dummies & INCL. & & INCL. & & INCL. & & INCL. & \\
\hline FIRM_dummies & INCL. & & INCL. & & INCL. & & INCL. & \\
\hline Constant & -4.493 & & -1.317 & & 6.490 & & -.282 & \\
\hline & {$[-0.88]$} & & {$[-0.41]$} & & [1.52] & & {$[-.05]$} & \\
\hline $\mathrm{R}^{2}$ & $48.3 \%$ & & $52.4 \%$ & & $47.5 \%$ & & $53.7 \%$ & \\
\hline $\mathrm{N}$ & 125 & & 125 & & 125 & & 125 & \\
\hline $\begin{array}{l}{ }^{* *}{ }^{*} \text { and }{ }^{* * *} \text { significant at resp } \\
\text { the coefficients, the t-statis } \\
+\beta_{3} P M C+\beta_{4} R I T+\beta_{5} F R \\
\beta_{10} \text { TONE_AT TOP }+\beta_{11} E \\
\beta_{15} \text { CLIENTIMPORTANCE } \\
+\beta_{20} \text { NOMINAL }+\beta_{21} \text { INDU }\end{array}$ & FIRM & & ENIORC & ulx & ${ }_{8} O P E N$ & niti & $\begin{array}{l}\text { table rep } \\
=\beta_{1}+\beta_{2} \\
\text { TEAMEX } \\
\text { ISDETEO } \\
\text { DUNDRO }\end{array}$ & $\begin{array}{l}\text { Oorts } \\
\text { HPS } \\
\langle P+ \\
\text { BI + } \\
\text { BIN }\end{array}$ \\
\hline
\end{tabular}


Table 3.7 Additional Analyses

\begin{tabular}{|c|c|c|c|c|}
\hline \multicolumn{5}{|c|}{ Panel A. Attendance and Communication } \\
\hline Independent Variable & HPS only & PMC only & RIT only & Full model \\
\hline HPS & $\begin{array}{r}.034 \\
\text { * } 911\end{array}$ & & & $\begin{array}{r}.015 \\
0871\end{array}$ \\
\hline$P M C$ & & $\begin{array}{r}.064 \\
{[3.81]}\end{array}$ & & $\begin{array}{r}.056 \\
{[3.11]}\end{array}$ \\
\hline$R I T$ & & & -.028 & -.020 \\
\hline Controls Included & & & {$[-1.54]$} & {$[-1.19]$} \\
\hline $\mathrm{R}^{2}$ & $43.2 \%$ & $48.4 \%$ & $42.3 \%$ & $49.4 \%$ \\
\hline \multicolumn{5}{|c|}{ Panel B. Structure and Timing } \\
\hline Independent Variable & HPS only & PMC only & RIT only & Full model \\
\hline HPS & $\begin{array}{r}.010 \\
{[1.08]}\end{array}$ & & & $\begin{array}{r}.010 \\
{[1.07]}\end{array}$ \\
\hline$P M C$ & & $\begin{array}{r}.004 \\
{[0.40]}\end{array}$ & & $\begin{array}{r}.000 \\
{[-0.01]}\end{array}$ \\
\hline$R I T$ & & & -.003 & -.003 \\
\hline Controls Included & & & {$[-0.39]$} & {$[-0.37]$} \\
\hline $\mathrm{R}^{2}$ & $32.3 \%$ & $31.4 \%$ & $31.4 \%$ & $32.4 \%$ \\
\hline \multicolumn{5}{|c|}{ Panel C. Engagement Team Effort } \\
\hline Independent Variable & HPS only & PMC only & RIT only & Full model \\
\hline HPS & $\begin{array}{r}.013 \\
{[0.78]}\end{array}$ & & & $\begin{array}{r}.004 \\
{[0.21]}\end{array}$ \\
\hline$P M C$ & & $\begin{array}{r}.030 \\
{[1.80]}\end{array}$ & & $\begin{array}{r}.027 \\
{[1.40]}\end{array}$ \\
\hline $\begin{array}{l}\text { RIT } \\
\text { Controls Included }\end{array}$ & & & $\begin{array}{r}-.018 \\
{[-1.09]}\end{array}$ & $\begin{array}{r}-.015 \\
{[-0.85]}\end{array}$ \\
\hline $\mathrm{R}^{2}$ & $47.1 \%$ & $48.8 \%$ & $47.5 \%$ & $49.3 \%$ \\
\hline
\end{tabular}

Next, we investigate when professional skepticism affects fraud brainstorming quality. The effect of professional skepticism could be dependent on different situational, organizational conditions. First, the effect of professional skepticism on FBQ could depend on the performance evaluation systems in place. Brazel et al. (2016) found that the outcome of the audit process biases the supervisor's evaluations of skeptical behavior. Their results showed that the auditors who employ an appropriate level of skepticism but do not identify a misstatement are penalized by the supervisors. Thus, professional skepticism might have a larger impact when a positive performance evaluation system is in place and professional skepticism is rewarded. To test this, we use the performance evaluation system measure of Cohen et al. (2017) and split the sample based on the mean of this variable. We find that when the audit firm is perceived as rewarding professional skepticism, high moral courage of the partner has a positive effect on fraud 
brainstorming quality. We do not find an effect of professional skepticism traits on FBQ when the firms do not reward professional skepticism. Next, the focus of the firm on professionalism versus commercialism might reinforce the effect of professional skepticism on FBQ. Using the measure of professional orientation of Wittek, van der Zee, and Mühlau (2008), we rerun the regression on a subsample split at the mean of the professional orientation variable. Untabulated results show that the professional moral courage of the partner has an effect in firms with a high professional orientation.

\subsection{CONCLUSIONS, LIMITATIONS AND DIRECTIONS FOR FUTURE RESEARCH}

Examining professional skepticism as a driver of fraud brainstorming quality, we find that the neutral trait skepticism and professional moral courage of the partner have a significant positive effect on fraud brainstorming quality. We do not find a significant effect for the presumptive doubt trait skepticism. More specifically, the descriptive statistics show higher attendance rate and contribution of specialists, more extensive discussion, longer preparation, and longer sessions for partners with high neutral trait skepticism and high moral courage. We find opposite results for partners with a high presumptive doubt trait. These results would suggest that the inverse of trust appears less appropriate to measure professional skepticism, while argued otherwise in prior literature (e.g., Quadackers et al. 2014). This conclusion is supported by recent findings in the literature showing that trust between auditors and clients will enhance professional skepticism (Aschauer, Fink, Moro, van Bakel-Auer, and Warming-Rasmussen 2017) and that trust is an important aspect in the audit process which can contribute to the independence of the auditor (Knechel et al. 2020). Further, additional analyses show that the effect of professional skepticism on FBQ depends on situational, organizational conditions. We only observe an effect of professional moral courage on fraud brainstorming quality in audit firms with a positive performance evaluation system and in firms with a high professional orientation. Last, we observe differences in fraud brainstorming quality between our Dutch sample compared to fraud brainstorming quality observed in the US, especially regarding fraud brainstorming attendance and communication. More specifically, the attendance rate and contribution of specialists is lower in our sample. With regard to structure and timing, and engagement team effort, we do not observe big differences. 
This study contributes to the literature by being the first to provide evidence for the relationship between an auditor's professional skepticism traits and fraud brainstorming quality. First, we address several calls in research to examine auditor characteristics (e.g., Defond and Zhang, 2014). DeFond and Zhang (2014, p. 304) 'encourage future research to consider additional individual auditor characteristics, such as professional skepticism, personality traits, gender, the complex audit team interactions, and the socio-economic characteristics.' Next, as a higher fraud brainstorming quality leads to better fraud risk identification and more effective audit plans to identify misstatements due to fraud, fraud brainstorming quality indirectly affects audit quality. Evidence for the relation between professional skepticism traits and fraud brainstorming quality therefore also is evidence for professional skepticism traits as an input for audit quality. The results of our study are not only relevant for academics, but also for audit practice, standard setters and regulators. Based on the insights from our study regarding fraud brainstorming quality and the underlying items across professional skepticism traits partitions, recommendations for fraud brainstorming practices might improve fraud brainstorming quality in practice. Further, the results of this study might help audit firms in selecting and training their people.

We note that these results should be interpreted with some possible limitations in mind. First, we cannot completely rule out the possibility that our results are driven by omitted variable bias. Second, the participants of our survey are all auditors in the Netherlands. It is possible that professional skepticism traits and organizational conditions differ across countries. 



\title{
CHAPTER 4. OUTPUT FACTORS
}

\begin{abstract}
This study investigates the relationship between audit partners' professional skepticism and publicly observable audit outcomes. We combine archival data on auditor reporting behavior with survey data on audit partners' level of professional skepticism, measured by the Hurtt Professional Skepticism Scale (HPS), the Professional Moral Courage Scale $(P M C)$ and the Rotter Interpersonal Trust Scale $(R I T)$. We find that clients audited by auditors with a higher score on HPS (i.e., higher neutral trait skepticism) are more likely to receive a going concern opinion (GCO). Further, the results show weak support for a positive relationship between higher professional moral courage and the likelihood of issuing a GCO. Conversely, we find weak evidence that higher scores on RIT (i.e., higher presumptive doubt trait skepticism) are negatively associated with observable audit outcomes. These results contribute to our understanding of professional skepticism in audit practice as this is one of the first studies examining the relationship between audit partners' professional skepticism and observable audit outcomes.
\end{abstract}

This chapter is based on a working paper with Kris Hardies, and Ann Vanstraelen.

We gratefully acknowledge the comments provided by Ann Gaeremynck (discussant), Clive Lennox, Mark Nelson, Dereck Barr-Pulliam (discussant), Luc Quadackers, participants at the 2016 Auditing Section Midyear Meeting, the 2018 International Symposium on Auditing Research and workshop participants at the University of Antwerp, Maastricht University, and KU Leuven. The study and research instrument were approved by the Ethics Committee for the Social Sciences and Humanities (EA SHW) of the University of Antwerp. We acknowledge the support of the Belgian Institute of Auditors (IBR, IRE) for facilitating this study. We gratefully thank Luc Quadackers for sharing the Dutch versions of the HPS and RIT scales. 


\subsection{INTRODUCTION}

The purpose of this study is to investigate the relationship between an auditor's level of professional skepticism and auditors' reporting behavior for a large sample of audit engagements. Professional skepticism is an important issue for the audit profession and has received considerable attention in recent years by academics (e.g., Nelson 2009; Hurtt et al. 2013; Quadackers et al. 2014), practitioners (e.g., GPPC 2013), standard-setters (e.g., PCAOB 2012; IAASB 2015) and regulators (e.g., IFIAR 2015; PCAOB 2015b). It is often argued that some audit failures could have been avoided if auditors would have been more skeptical (e.g., Beasley et al. 2001; PCAOB 2008; IFIAR 2015). Furthermore, independent public oversight bodies have repeatedly expressed concerns on the level of professional skepticism as a factor underlying many audit deficiencies (e.g., IFIAR 2012, 2015). Hence, regulators argue that 'enhancing professional skepticism of practitioners contributes significantly to quality financial statement audits' (IFIAR 2015, p.3).

While a number of laboratory experiments have investigated associations between professional skepticism and auditor judgments and decisions (e.g., Rose 2007; Quadackers et al. 2014; Bowlin et al. 2015), there is very limited archival evidence that contextualizes such findings (e.g., helps understand the relative importance of professional skepticism on audit practice).$^{42}$ In the current paper, we focus specifically on auditors' "trait skepticism" (i.e., skepticism as a stable personality characteristic). The importance of such traits in explaining attitudes and behaviors has been widely established in personality psychology (McCrae and Costa, 1995; John et al. 2008) and is acknowledged in theoretical models on auditor professional skepticism as well (Nelson 2009; Glover and Prawitt 2013; Hurtt et al. 2013; Nolder and Kadous 2018). Prior experimental research has documented variations in auditors' trait skepticism and also shows that such trait skepticism can predict skeptical behaviors (e.g., Quadackers et al. 2014). That is, variations in trait skepticism leads auditors to make different judgments and to display different behaviors even when facing similar situations or circumstances. However, personality dispositions (traits) do not necessarily determine single, contextualized behaviors (because our behavior is also affected by situations), but they do determine patterns of behaviors over time and across situations (i.e., they predict how people will behave on average). That is, the predictive power of personality traits increases to the extent that behaviors are aggregated over occasions and situations (Epstein

\footnotetext{
Using archival data, Feng and $\mathrm{Li}$ (2014) looked at the weight that auditors assign to management forecasts when making going concern decisions to infer whether auditors exercise professional skepticism (i.e., act skeptically). In a working paper, Knechel, Sofla, and Svanström (2015b) report that trait skepticism is positively associated with auditors' compensation in Big 4 accounting firms.
} 
1979; Fleeson and Gallagher 2009). When many measurements of behavior are combined, there is much clearer evidence for the stability of traits and for the effects of traits on behavior (Roberts and DelVecchio, 2000; Srivastava, John, Gosling, and Potter, 2003). Hence, personality traits are more likely to be predictive of aggregated (archival) audit outcomes than of single (experimental) judgments or behaviors (unlike experimental research, our archival data allow to capture naturally occurring, representative behaviors of individuals).

Linking trait skepticism to observable audit outcomes (e.g., audit opinions) is however challenging because it requires both the reliable measurement of trait skepticism and appropriate ways to link such measurements to audit outcomes. Furthermore, while it seems intuitive that variations in trait skepticism would also drive audit outcomes, it remains an empirical question whether differences in trait skepticism have small or large effects on audit outcomes. In practice, various factors within an audit engagement (investigated in isolation in experimental settings) can offset or interact with each other in creating audit outcomes (Nelson 2009; Aobdia 2019).

This paper examines whether the trait professional skepticism of signing partners is predictive of actual audit quality outcomes as revealed by audit opinions. It is not a priori clear whether this association will be observed in audit practice given that auditing standards require all auditors to exercise professional skepticism for each engagement. Furthermore, audit firms have standard methodologies in place for conducting an audit, and the auditor's work is subject to engagement quality control review (e.g., ISQC1). Hence, whether higher or lower levels of individual auditor's professional skepticism ultimately affect publicly observable audit outcomes is an empirical question. We address this question in this study and respond to a recent call by DeFond and Zhang (2014, p. 304) who 'encourage future research to consider additional individual auditor characteristics, such as professional skepticism' and its role in providing high audit quality.

To address this research question, we exploit the Belgian setting which has a long history of disclosure of signing audit partners, and combine survey evidence eliciting the trait skepticism of those partners with archival evidence of audit quality outcomes for the companies they audit. ${ }^{43}$ Given multiple extant definitions of professional skepticism, we use multiple measures that have been proposed in prior research to capture the presumptive doubt definition (in which auditors tend to assume some level of bias or dishonesty on the part of management; Bell et al. 2005), measured by the Rotter Interpersonal Trust Scale $(R I T)$, the neutral definition (in which auditors

43 The auditors were informed that the survey was part of a research project on how personality traits could influence the performance of certain audit engagements, and that all data would be treated in a confidential way according to the Belgian privacy laws. The study and the research instrument were approved by the Ethics Committee for the Social Sciences and Humanities of the University of Antwerp. 
neither view managers as honest nor as dishonest; O'Malley, 2000), measured by the auditingfocused professional skepticism scale by Hurtt (2010) (HPS), and the professional moral courage definition (Hurtt et al. 2013), measured by the Professional Moral Courage Scale (PMC). Consistent with the PCAOB's (2015a) recent concept release examining audit quality indicators, we consider going concern opinions as audit quality indicators. Based on a large sample of Belgian companies, we find evidence of a positive association between auditors with higher neutral trait skepticism (HPS) and the likelihood of issuing GCOs for a sample of financially distressed companies. Further, the results show weak evidence for a positive relationship between higher professional moral courage $(P M C)$ and the auditor's reporting behavior. Conversely, we find weak support for a negative relationship between higher presumptive doubt trait skepticism $(R I T)$ and the likelihood of issuing GCOs.

We make a number of important contributions to the literatures on professional skepticism and audit partners by combining pre-structured and hand-collected archival data with survey data from a representative sample of audit partners. An advantage of this method is that we have both (a) reliable measures of professional skepticism traits (which is mostly the case for experiments, but typically not for archival studies looking at professional skepticism), and (b) publicly available output-based measures of audit quality (which is typical for archival studies but not for experiments). Mostly, experiments have to rely on cases or simplified experimental designs in which one has to look at just one specific part of the audit, and where one cannot take into account factors that in the real world could potentially counteract the effect of individual professional skepticism, such as audit firms' quality control mechanisms. Therefore, the combination of prestructured and hand-collected archival data and survey data offers a unique opportunity to generalize and contextualize the results from laboratory experiments on professional skepticism (Nelson and Skinner 2013; Bloomberg, Nelson, and Soltes 2016). This examination is important because prior research as well as audit practice have proposed auditor attributes like professional skepticism as drivers of audit quality without much supporting empirical evidence (DeFond and Zhang, 2014, p. 304). Prior experimental studies provide some evidence that trait skepticism affects audit judgments, but experiments are not well suited to link those judgments with actual audit outcomes. Therefore, evidence of a relation between trait skepticism and audit quality outcomes contributes to both literatures by supporting the effectiveness of trait skepticism measurement techniques and the underlying theory linking trait skepticism to audit judgments, decisions, and outcomes. In addition, evidence comparing alternative trait skepticism measures helps to parse the relative importance of neutrality and presumptive doubt as determinants of audit quality outcomes. 


\subsection{LITERATURE REVIEW AND HYPOTHESIS}

In response to calls for more research into individual auditor characteristics (Francis 2011; Knechel et al. 2013), an increasing number of recent (archival) studies (e.g., Zerni, 2012; Ittonen, Vähämaa, and Vähämaa 2013; Gul, Donghuis, and Zhifeng 2013; Knechel, Vanstraelen, and Zerni 2015a; Hardies, Breesch, and Branson 2016; Kallunki, Kallunki, Niemi, and Hilsson 2019) has focused on the impact of individual audit partners on audit quality (see Lennox and Wu (2018) for an overview). These studies provide evidence that the individual audit partner affects the outcome of the audit. DeFond and Zhang (2014, p. 304) specifically called for 'future research to consider additional individual auditor characteristics, such as professional skepticism.' PCAOB inspections (PCAOB 2015b) and IFIAR inspections (IFIAR 2015) frequently cite professional skepticism as a factor underlying audit deficiencies.

Three definitions of professional skepticism are emphasized in the extant literature. First, under the neutral definition (O'Malley 2000), professional skepticism 'includes a questioning mind and a critical assessment of audit evidence. [...] The auditor neither assumes that management is dishonest nor assumes unquestioned honesty' (AU 230.07-09). The neutral definition is referenced in numerous audit standards, as well as in the PCAOB's Staff Audit Practice Alert No. 10 that is focused on professional skepticism (PCAOB 2012). International auditing standards use similar wording (IAASB 2012, ISA 200.15-16). To capture traits consistent with the neutral view of professional skepticism, the Hurtt Professional Skepticism Scale (HPS) can be used (Quadackers et al. 2014). It includes questions designed to assess whether an auditor has a questioning mind, is willing to suspend judgment, searches for knowledge, has interpersonal understanding, and has autonomy and self-esteem. In other words, it focuses on having and pursuing doubt as opposed to a particular direction of doubt. Prior experimental studies provide evidence that the Hurtt scale has some ability to predict skeptical judgments by auditors (e.g., Hurtt et al. 2012; Quadackers et al. 2014) and (accounting) students (e.g., Popova 2012; Bhaskar, Majors, and Vitalis 2016; Olsen, Brevik, Lundervold, and Stuart 2017), although some fail to find evidence of such relation (e.g., Rasso 2015). Second, under the presumptive doubt definition of professional skepticism, auditors have relatively more doubt about the validity of an assertion than about its invalidity, assuming some level of management bias or dishonesty by management unless evidence indicates otherwise (Bell et al. 2005). This definition is consistent with fraud standards (AU 316.13; ISA 240.24). Under this view, skepticism is the opposite of trust (Shaub 1996). Prior research has found inconsistent relations between certain trust measures and auditor judgments (e.g., Shaub 1996; Choo and Tan 2000; Rose 2007; Rennie et al. 2010). However, as noted by Quadackers et al. (2014), a scale developed by Rotter (1967) may better capture traits 
consistent with the presumptive doubt view of professional skepticism. The Rotter Interpersonal Trust Scale $(R I T)$ is intended to capture 'a generalized expectancy held by an individual or a group that the word, promise, verbal or written statement of another individual or group can be relied upon' (Rotter 1967, p. 651). Quadackers et al. (2014) show a negative relation between RIT and skeptical judgments in case of high control environment risk. Third, under the professional moral courage definition of professional skepticism, auditors vary in their willingness to take skeptical actions (Hurtt et al. 2013). To capture traits consistent with the professional moral courage view of professional skepticism, the Professional Moral Courage Scale (PMC) can be used (Sekerka et al. 2009). The Professional Moral Courage Scale is intended to assess five dimensions: moral agency, multiple values, endurance of threats, going beyond compliance, and moral goals.

The importance of professional skepticism derives from its asserted linkage to audit outcomes. Research has attempted to model or conceptualize professional skepticism and better understand that linkage. For example, Nelson (2009) models professional skepticism in audit outcomes as a consequence of the way in which auditor traits, knowledge, and incentives combine to affect auditor judgments and actions. Hurtt et al. (2013) group many of the same constructs in four categories: auditor characteristics (including traits), evidential characteristics, client characteristics, and external environment characteristics. Like Nelson (2009), Hurtt et al. (2013) consider how these constructs affect judgment and, conditional on judgment, action. Glover and Prawitt (2013) likewise view professional skepticism as arising from a combination of personal traits, knowledge, and skill. Nolder and Kadous (2018) conceptualize professional skepticism as an attitude that is reflected in auditor judgments, feelings and actions, with traits implicit in the attitude as well as potentially moderating the extent to which it affects outcomes.

A common feature of all of these models and conceptualizations is that auditors possess some relatively stable traits, or predispositions, that affect the extent to which they behave and act skeptically in a particular audit situation. Our focus is on measuring that "trait skepticism" and relating it to audit outcomes. Prior experimental research has shown that auditor professional skepticism traits are associated with auditor judgments and decisions (e.g., Rose 2007; Rennie et al. 2010; Hurtt et al. 2012; Quadackers et al. 2014). However, whether higher or lower levels of individual auditor's professional skepticism will ultimately affect publicly observable audit outcomes in audit practice is not clear given that auditing standards require all auditors to exercise professional skepticism for each engagement. It might be that the partner's professional skepticism is irrelevant for audit outcomes because professional standards require the partner to accurately make going concern judgments regardless. Furthermore, audit firms have standard 
methodologies in place for conducting an audit, and the auditor's work is subject to engagement quality control review (e.g., ISQC1).

The PCAOB's concept release lists "timely reporting of going concern issues" as an audit quality indicator, and reports that "'Failure to include a going concern paragraph within an audit report in the face of an issuer's reasonably foreseeable business distress ... can indicate issues about the effectiveness of the auditing involved" (PCAOB 2015a, p. A-23). Auditors with higher trait skepticism might be more willing to issue GCO's, either because they do the work necessary to identify going concern issues or are less willing to accept client assertions that those issues will resolve favorably. Consequently, we predict a positive relation between trait skepticism and the likelihood that the auditor expresses a GCO by testing the following hypothesis:

H1: Auditor trait skepticism affects actual audit reporting decisions.

Figure 4.1 illustrates our conceptual model. We expect a positive effect of professional skepticism traits on the likelihood that the auditor issues a GCO, while controlling for other individual characteristics (gender and experience), and situational characteristics (i.e., client and audit firm characteristics; e.g., risky clients, important clients, Big4 auditor).

\section{Professional Skepticism}

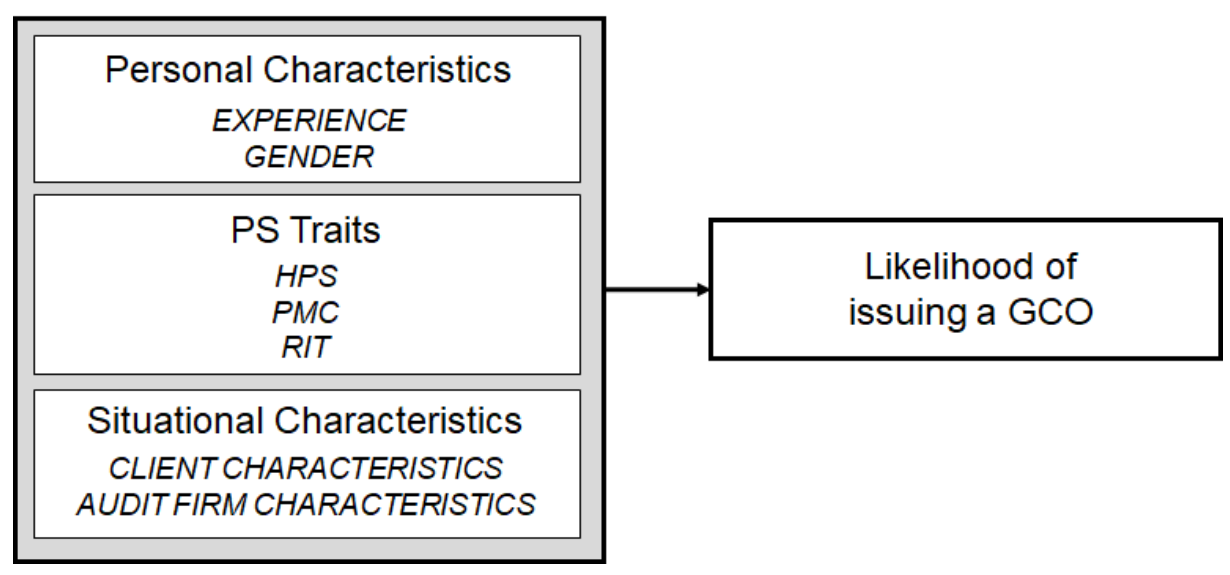

Figure 4.1 Conceptual model 


\subsection{Methodology}

\section{Data}

To investigate the relationship between skeptical auditor characteristics and audit outcomes, we combine survey data on individual auditors with publicly available, archival data. We infer audit quality from a commonly used measure in the literature: the likelihood of GCOs for financially distressed companies.

We collected financial statement data for all audited companies in Belgium for the period 20112014 from the database "Bel-First", developed by Bureau Van Dijk. We hand-collected data on audit partner identities and going concern opinions from the Belgian National Bank. Additional information, including data on audit partners, was retrieved from the public register of auditors.

To measure auditor trait skepticism, we composed a survey including the Hurtt Professional Skepticism Scale (HPS) (Hurtt 2010), the Professional Moral Courage Scale (PMC) (Sekerka et al. 2009), and Rotter's Interpersonal Trust Scale (RIT) (Wrightsman 1991). The score on HPS is used to measure neutral trait skepticism and a higher score indicates a higher neutral trait skepticism. The score on PMC provides a measure of professional moral courage and a higher score suggests that the auditor is more willing to take skeptical actions. Adding up the scores of the Rotter Interpersonal Trust Scale provides the interpersonal trust score with higher scores indicating higher interpersonal trust. Consistent with Quadackers et al. (2014), the reverse of the score $(R I T)$ is used to measure presumptive doubt trait skepticism. A higher score on $R I T$ indicates higher distrust.

In order to minimize translation bias, we used the Dutch version of the Hurtt Professional Skepticism scale and Rotter's Interpersonal Trust scale which were used in the study of Quadackers et al. (2014). Further, a French translation of both scales and a translation of the Professional Moral Courage scale were developed using a combination of the Parallel Blind Technique and Translation/Back-Translation methods (Behling and Law 2000). ${ }^{44}$ A pilot-test was conducted with 8 auditors and on the basis of their feedback, minor modifications were made to the research-instrument before sending it to the entire population of audit partners in Belgium.

Invitations to participate in the study were first sent via e-mail in September 2014 to all (819) auditors registered in Belgium for whom an e-mail address was available. ${ }^{45}$ Two weeks later, a reminder was sent. To increase the response rate, the survey was also send on paper to the 250

44 French is the second native language in Belgium.

45 We consider HPS, PMC and RIT to be traits and hence to be individual characteristics that are stable by the time an auditor commences audit training and practice (Libby and Luft 1993; Nelson 2009). 
auditors with most clients in the sample period. ${ }^{46}$ In total, 245 responses were received, corresponding to a response rate of $30 \%$, which is comparable with other surveys in accounting research (e.g., 16\% response rate by Nelson et al. (2002); see Nkansa and Bailey 2018). Of these responses, 48 responses had insufficient data for all the scales. ${ }^{47}$ Further, as shown in Table 4.1 (Panel A), we exclude data from 53 auditors who did not sign audit opinions during our sample period. This selection process yields data from 144 audit partners to match with our archival data.

Table 4.1 Survey Responses and Sample Composition

\begin{tabular}{|c|c|c|}
\hline Selected auditors for survey & 819 & \\
\hline Respondents (response rate) & $245(30 \%)$ & \\
\hline Missing survey data for HPS, $P M C$ and $R I T$ & (48) & \\
\hline Auditors not signing audit opinions in 2011-2014 & (53) & \\
\hline Available audit engagement partners for archival analyses & 144 & \\
\hline \multicolumn{3}{|l|}{ Panel B. Sample derivation } \\
\hline $\begin{array}{l}\text { Firm-year observations for the period } 2011-2014 \text { for auditors } \\
\text { in survey sample (144 auditors) }\end{array}$ & & 20,504 \\
\hline $\begin{array}{l}\text { Less joint-audits, financial institutions }{ }^{a} \text { and public } \\
\text { administrative institutions }{ }^{b}\end{array}$ & & $(2,186)$ \\
\hline Less observations with missing financial statement data & & $(8,503)$ \\
\hline Less observations for non-financially distressed companies & & $(5,143)$ \\
\hline Final sample available for GCO analyses & & 4,672 \\
\hline Number of unique audit partners in GCO sample & 118 & \\
\hline \multicolumn{3}{|c|}{$\begin{array}{l}\text { This table presents survey response and sample composition. } \\
\text { a Financial institutions are excluded because of their specific accounting requirements, which differ substantially } \\
\text { from those of industrial and commercial companies } \\
\text { b Public administrative institutions are excluded because of their specific nature }\end{array}$} \\
\hline
\end{tabular}

The majority (67\%) of the participants completed the survey in Dutch. Descriptive statistics on auditor trait skepticism are shown in Table 4.2. The mean scores for RIT and HPS are 78.99 and 137.78, respectively. These values are similar to those reported by Quadackers et al. (2014) who report mean scores of respectively 72.98 (vs. 70.95 in our sample) and 131.66 for their sample of 96 Dutch auditors. The mean score for $P M C$ is 85.93 . Further, the Cronbach alpha values for the

46 There are no systematic differences between the responses on paper and the responses by e-mail in terms of professional skepticism traits and language. As the paper-and-pencil survey was send to the 250 auditors with most clients in the sample period, male auditors, more experienced auditors, and Big 4 auditors are overrepresented among these respondents. Analyses using the paper-and-pencil or e-mail responses only yield similar results and conclusions.

47 An additional 27 responses contained missing data for either HPS, PMC or RIT. All reported analyses include the available information (i.e., either HPS, PMC or RIT) from these 27 responses. Using complete responses only (i.e., HPS, PMC and RIT available) yields similar results and conclusions for all our analyses. 
scales are acceptable, 0.92 for PMC, 0.79 for RIT and 0.88 for HPS. HPS and PMC are significantly correlated ( $r=0.469)$, and the correlation between HPS and RIT, and PMC and RIT is small (respectively $r=-0.012$ and 0.105 ). This suggests that they represent separate constructs.

Table 4.2 Descriptive Statistics for the Scales Measuring Professional Skepticism Traits

\begin{tabular}{|c|c|c|c|c|c|c|}
\hline Measurement scale & $\begin{array}{l}\text { Mean } \\
\text { score }\end{array}$ & $\begin{array}{l}\text { Standard } \\
\text { deviation }\end{array}$ & $\begin{array}{c}\text { Theoretical } \\
\text { range }\end{array}$ & $\begin{array}{l}\text { Actual } \\
\text { range }\end{array}$ & $\begin{array}{l}\text { Theoretical } \\
\text { midpoint }\end{array}$ & $\begin{array}{l}\text { Cronbach } \\
\text { alpha }\end{array}$ \\
\hline $\begin{array}{l}\text { Hurtt Professional } \\
\text { Skepticism Scale }\end{array}$ & 137.78 & 13.43 & $30-180$ & $109-175$ & 105 & 0.88 \\
\hline $\begin{array}{l}\text { Professional Moral } \\
\text { Courage Scale }\end{array}$ & 85.93 & 9.54 & $15-105$ & 58.5-105 & 60 & 0.92 \\
\hline $\begin{array}{l}\text { Rotter Interpersonal } \\
\text { Trust Scale }(R)^{\star}\end{array}$ & 78.99 & 10.09 & $25-125$ & $48-109$ & 75 & 0.79 \\
\hline
\end{tabular}

For our empirical analyses on auditor trait skepticism and audit outcomes, we need to match our survey data with archival data from financial statements and audit opinions. The archival sample selection started from the sample of 20,504 firm-year observations that during the sample period 2011-2014 were audited by the 144 audit partners for which we have survey data on HPS, $P M C$ and RIT available (Table 4.1, Panel B). From this sample, we dropped observations with joint-audits, financial institutions, and public administrative institutions. Further, we dropped observations with missing financial statement. Following prior research (e.g., DeFond, Raghunandan and Subramanyam 2002; Reynolds and Francis 2000) we limit our sample to financially distressed firms. Consistent with prior research (e.g., Mutchler, Hopwood, and McKeawn 1997; Hardies et al. 2016, 2018), we consider a firm to be financially distressed if it exhibits one of the following criteria: (1) an operational loss, (2) a bottom line loss, (3) negative retained earnings, or (4) negative working capital. This yields a sample of 4,672 observations, audited by 118 auditor partners.

In order to test the representativeness of our final samples, we compare the auditors from our final sample with all survey respondents and with all auditors for which information is available. Table 4.3 (Panel A) shows how the variables of interest (HPS, PMC and RIT) differ between auditors from the full survey sample and auditors from the GCO samples. The difference in variation in the scores of HPS, PMC and RIT is very limited across the samples. The mean score of auditors on HPS varies between 137.39 in the GCO sample (relating to 108 auditors) and 137.78 in the full survey sample (relating to 130 auditors), on PMC between 85.46 in the GCO sample (relating to 108 auditors) and 85.93 in the full survey sample (relating to 130 auditors) and 
on RIT between 78.75 in the GCO sample and 78.99 in the full survey sample. Table 4.3 (Panel B) also shows that there are no systematic differences between respondents and nonrespondents in terms of demographics such as gender, language, experience, and Big 4 affiliation. Hence, we conclude that our sample for our GCO analysis is likely to be representative in terms of professional skepticism traits (HPS, PMC and RIT) for the population of Belgian auditors.

Table 4.3 Representativeness of Auditors in Samples

\begin{tabular}{|c|c|c|c|c|c|c|}
\hline \multicolumn{7}{|c|}{ Panel A. Auditor Trait Skepticism } \\
\hline Variables & Sample & $\mathrm{N}$ auditors & Mean & Std. Dev. & Min & Max \\
\hline \multirow{2}{*}{ HPS } & Usable responses & 130 & 137.78 & 13.43 & 109 & 175 \\
\hline & GCO & 108 & 137.39 & 13.09 & 109 & 173 \\
\hline \multirow{2}{*}{$P M C$} & Usable responses & 130 & 85.93 & 9.54 & 58.5 & 105 \\
\hline & GCO & 109 & 85.46 & 9.66 & 58.5 & 105 \\
\hline \multirow{2}{*}{ RIT } & Usable responses & 135 & 78.99 & 10.09 & 48 & 109 \\
\hline & GCO & 112 & 78.75 & 9.73 & 51 & 102 \\
\hline \multicolumn{7}{|c|}{ Panel B. Auditor Demographics } \\
\hline Variables & Sample & $\mathrm{N}$ auditors & Mean & Std. Dev. & Min & Max \\
\hline \multirow{3}{*}{ GENDER } & All observations & 784 & .16 & .36 & 0 & 1 \\
\hline & Usable responses & 144 & .12 & .32 & 0 & 1 \\
\hline & GCO & 118 & .11 & .31 & 0 & 1 \\
\hline \multirow{3}{*}{$L A N G$} & All observations & 784 & .37 & .48 & 0 & 1 \\
\hline & Usable responses & 144 & .39 & .49 & 0 & 1 \\
\hline & GCO & 118 & .39 & .49 & 0 & 1 \\
\hline \multirow{3}{*}{ EXP } & All observations & 784 & 17 & 8.58 & 0 & 42 \\
\hline & Usable responses & 144 & 16 & 8.76 & 0 & 36 \\
\hline & GCO & 118 & 18 & 7.96 & 0 & 36 \\
\hline \multirow{3}{*}{ BIG4 } & All observations & 784 & .26 & .44 & 0 & 1 \\
\hline & Usable responses & 144 & .33 & .47 & 0 & 1 \\
\hline & GCO & 118 & .34 & .48 & 0 & 1 \\
\hline
\end{tabular}




\section{Research Design}

As outlined above, we use the likelihood of a GCO, a publicly available audit outcome, to proxy for audit quality. In order to test the relationship between auditor trait skepticism and the likelihood of a GCO, we estimate the following logistic regression:

$$
\begin{aligned}
\text { GCO }_{i t}= & \beta_{1}+\beta_{2} P_{i t}+\beta_{3} L_{N T A_{i t}}+\beta_{4} \text { LOSS }_{i t}+\beta_{5} \text { ROA }_{i t}+\beta_{6} \text { INVREC }_{i t}+B_{7} \text { CURRENT }_{i t}+ \\
& \beta_{8} \text { PROBANKF } \\
& \beta_{12} \text { EXPERIENCE }_{i t}+\beta_{13} \text { FYE }_{i t}+\beta_{14} \text { LIST }_{i t}+\beta_{15} \text { INDUSTRY }_{i t}+\beta_{16} \text { YEAR }_{i t}+\varepsilon_{i t}
\end{aligned}
$$

The dependent variable, GCO, is a dummy variable that takes a value of 1 for companies that received a going concern opinion and 0 otherwise. The variable of interest in the GCO model is $P S$, measured as either HPS (to test neutral trait skepticism), PMC (to test professional moral courage) or RIT (to test presumptive doubt trait skepticism). ${ }^{48}$ Consistent with prior literature (e.g., Craswell, Stokes, and Laughton 2002; Robinson 2008; Carcello, Vanstraelen, and Willenborg 2009; Francis and Yu 2009; Goodwin and Wu 2015; Kallunki et al. 2019), we include control variables which have been shown to be related to the likelihood of issuing a GCO. Specifically, LNTA, the natural logarithm of total assets, represents client size; LOSS, which is a dummy variable that takes a value of 1 for companies that have an operating loss and 0 otherwise; INVREC, which is inventories and receivables divided by total assets; $R O A$, which is net income divided by total assets; CURRENT, which is current assets divided by current liabilities; and PROBANKF, which is the score of a standardized bankruptcy prediction model developed for Belgian companies (Ooghe and Spaenjers 2005). Following Craswel et al. (2002) and Francis and Yu (2009), we include INFLUENCE, representing auditors' incentives with respect to a client's influence on the local office, which is measured as a dummy variable that takes the value of 1 for clients which are listed or within $10 \%$ of the largest clients of the audit office. Further, we include $B I G 4$, a dummy variable that takes the value of 1 for companies that are audited by a Big 4 audit firm; and GENDER, a dummy variable that takes the value of 1 for female auditors. We also control for auditor EXPERIENCE measured as the experience of the auditor in years; financialyear end, $F Y E$, which is a dummy variable that takes a value of 1 if the company has a December year end and 0 otherwise; and LIST, a dummy variable taking the value of 1 in case of a publicly listed client company. Finally, we include industry and year fixed effects and all regressions are

48 In our main analyses, we include HPS, PMC and RIT separately in our regression. In additional analyses, we also include HPS, PMC and RIT simultaneously in the regression model. 
based on robust standard errors clustered at client firm level. ${ }^{49}$ All continuous variables are winsorized at the $1^{\text {st }}$ and $99^{\text {th }}$ percentile..$^{50}$

\subsection{RESULTS}

\section{Descriptive Statistics}

Descriptive statistics for all variables used in this study are reported in Table 4.4 (Panel A). In our sample, $25 \%$ financially distressed firms received a GCO, which is comparable to previous research using Belgian data (e.g., Gaeremynck and Willekens 2003; Knechel and Vanstraelen 2007; Hardies et al. 2016). The average natural log of total assets is 16.02 , relating to an average total of assets of 52,1 million euros. Fifty percent of the companies experienced losses (LOSS). Companies in the sample have a mean ROA of -0.01 ; INVREC of 0.46 ; and CURRENT of 2.30. The mean PROBANKF for the companies is 0.53 . Given that bankruptcy scores below 0.531 indicate acute financial problems (Ooghe and Spaenjers 2005), our sample selection procedure has successfully identified companies for which the auditor can be expected to consider issuing a GCO. Only $10 \%$ of the clients have a considerable influence on the audit office. Furthermore $45 \%$ of the companies are audited by a Big 4 auditor, $11 \%$ of the clients are audited by a female audit partner, and by an auditor with an average experience of 19 years. Finally, the descriptive statistics show that $85 \%$ of the companies in the sample use 31 December as their balance sheet date, and the percentage of listed companies is $0.6 \%$, which is representative for the Belgian population of companies subject to a statutory audit.

We also test whether auditors' trait skepticism varies with certain auditor and client characteristics. Results are shown in Table 4.4 (Panel B) and suggest that auditors with a higher score on HPS and PMC have significantly larger clients (LNTA). Further, the group of auditors with higher HPS (PMC) scores contains 21\% (30\%) more auditors who are affiliated with the Big 4 than the group with lower HPS scores. The opposite is observed with respect to RIT. Auditors with higher presumptive doubt trait skepticism (higher reversed RIT scores) have, on average, smaller clients (LNTA). The group of auditors with higher presumptive doubt trait skepticism contains 30\% less auditors who are affiliated with the Big 4 and $7 \%$ less women than the group with high $R I T$ scores.

49 We do not include partner fixed effects in our models as our variable of interest (PS) is a time-invariant partner characteristic. We also do not include company fixed effects in our regressions, as our time period is short (resulting in just a small number of observations per client), and because the specifications with company fixed effects are difficult to estimate due to the binary nature of our dependent variable (Knechel et al. 2015a).

50 All results are very similar to those reported if variables are not winsorized. 
Table 4.4 Descriptive Statistics

\begin{tabular}{lrrrrrr}
\hline \multicolumn{7}{l}{ Panel A. Descriptive statistics for regression variables (firm-year observations) } \\
\hline Variable & $\mathrm{N}$ & Mean & Std. Dev. & Median & Min & Max \\
\hline GCO & 4672 & .25 & .43 & 0 & 0 & 1 \\
HPS & 4453 & 138.12 & 13.77 & 140 & 109 & 173 \\
PMC & 4427 & 85.37 & 9.20 & 88.50 & 58.50 & 105 \\
RIT & 4541 & 77.89 & 9.69 & 79 & 51 & 102 \\
LNTA & 4672 & 16.02 & 1.78 & 15.91 & 12.30 & 20.74 \\
LOSS & 4672 & .50 & .50 & 1 & 0 & 1 \\
ROA & 4672 & -.01 & .17 & .02 & -.68 & .55 \\
INVREC & 4672 & .46 & .30 & .47 & 0 & .99 \\
CURRENT & 4672 & 2.30 & 7.33 & .97 & .05 & 63.6 \\
PROBANKF & 4672 & .53 & .06 & .54 & .18 & .74 \\
INFLUENCE & 4672 & .10 & .30 & 0 & 0 & 1 \\
BIG4 & 4672 & .45 & .50 & 0 & 0 & 1 \\
GENDER & 4672 & .11 & .32 & 0 & 0 & 1 \\
LANG & 4672 & .27 & .45 & 0 & 0 & 1 \\
EXP & 4672 & 18.60 & 7.00 & 18 & 0 & 39 \\
FYE & 4672 & .85 & .35 & 1 & 0 & 1 \\
LIST & 4672 & .01 & .08 & 0 & 0 & 1
\end{tabular}

Panel B. Differences in client and auditor characteristics for high vs. low auditor trait skepticism (audit partner observations)

\begin{tabular}{|c|c|c|c|c|c|c|c|c|c|}
\hline & \multicolumn{3}{|c|}{ HPS } & \multicolumn{3}{|c|}{$P M C$} & \multicolumn{3}{|c|}{ RIT } \\
\hline & $\underline{\Delta}$ & $\underline{t}$ & $\underline{p}$ & $\underline{\Delta}$ & $\underline{t}$ & $\underline{p}$ & $\underline{\Delta}$ & $\underline{t}$ & $\underline{p}$ \\
\hline LNTA & 0.10 & 1.82 & 0.07 & 0.26 & 5.07 & 0.00 & -0.39 & -7.46 & 0.00 \\
\hline LOSS & -0.01 & -0.40 & 0.69 & 0.03 & 1.89 & 0.06 & 0.01 & 0.78 & 0.43 \\
\hline$R O A$ & 0.00 & 0.26 & 0.80 & 0.00 & 0.78 & 0.43 & 0.00 & 0.11 & 0.91 \\
\hline INVREC & 0.03 & 2.82 & 0.00 & 0.01 & 1.37 & 0.17 & -0.01 & -1.32 & 0.19 \\
\hline CURRENT & 0.07 & 0.34 & 0.74 & -0.02 & -0.09 & 0.93 & -0.60 & -2.80 & 0.01 \\
\hline PROBANKF & 0.01 & 2.61 & 0.01 & 0.00 & 0.18 & 0.85 & 0.00 & 0.05 & 0.96 \\
\hline INFLUENCE & 0.00 & 0.32 & 0.75 & 0.01 & 0.81 & 0.42 & -0.03 & -3.65 & 0.00 \\
\hline BIG4 & 0.21 & 14.35 & 0.00 & 0.30 & 21.10 & 0.00 & -0.29 & -20.4 & 0.00 \\
\hline GENDER & 0.07 & 7.38 & 0.00 & -0.05 & 5.12 & 0.00 & -0.07 & -8.00 & 0.00 \\
\hline LANG & 0.11 & 8.24 & 0.00 & 0.21 & 16.69 & 0.00 & -0.13 & -10.04 & 0.00 \\
\hline$E X P$ & -2.44 & -11.95 & 0.00 & 0.54 & 2.63 & 0.01 & 5.94 & 32.02 & 0.00 \\
\hline FYE & 0.01 & 1.16 & 0.25 & 0.00 & 0.22 & 0.83 & 0.01 & 0.95 & 0.34 \\
\hline LIST & 0.00 & 0.22 & 0.82 & -0.01 & -2.41 & 0.02 & 0.00 & 1.44 & 0.15 \\
\hline
\end{tabular}




\begin{tabular}{|c|c|c|c|c|c|c|c|c|c|c|c|c|}
\hline & $\begin{array}{l}\text { O } \\
\text { ত }\end{array}$ & $\begin{array}{l}\infty \\
\frac{2}{1}\end{array}$ & $\sum_{2}^{0}$ & $\stackrel{\hbar}{\mathbb{x}}$ & $\underset{⿱}{\Sigma}$ & $\begin{array}{l}\infty \\
\infty \\
0\end{array}$ & 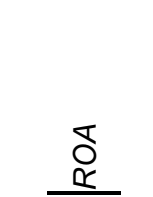 & $\begin{array}{l}\underset{\sim}{\sim} \\
\stackrel{\sim}{\gtrless} \\
\geqq\end{array}$ & 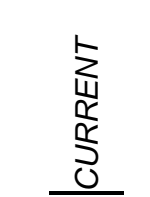 & $\begin{array}{l}\frac{1}{1} \\
\vdots \\
\vdots \\
0 \\
0 \\
\frac{1}{2} \\
2\end{array}$ & 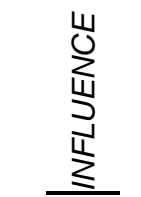 & VIF \\
\hline HPS & $0.0412^{*}$ & 1.0000 & & & & & & & & & & 1.59 \\
\hline$P M C$ & 0.0034 & $0.4686^{*}$ & 1.0000 & & & & & & & & & 1.83 \\
\hline$R I T$ & 0.0126 & $-0.0123^{*}$ & $0.1049^{*}$ & 1.0000 & & & & & & & & 1.20 \\
\hline LNTA & $-0.2258^{\star}$ & $0.0266^{*}$ & $0.0497^{*}$ & $-0.1086^{\star}$ & 1.0000 & & & & & & & 1.82 \\
\hline LOSS & $0.2278^{*}$ & -0.0058 & 0.006 & 0.0114 & $-0.1445^{*}$ & 1.0000 & & & & & & 1.53 \\
\hline$R O A$ & $-0.1930^{*}$ & -0.0037 & -0.0240 & 0.0016 & $0.1398^{*}$ & $-0.5273^{*}$ & 1.0000 & & & & & 1.97 \\
\hline INVREC & $0.1230^{\star}$ & $0.0412^{*}$ & $0.0662^{*}$ & -0.0194 & $-0.1811^{*}$ & $0.1755^{\star}$ & $-0.0957^{*}$ & 1.0000 & & & & 1.36 \\
\hline CURRENT & $-0.0729^{*}$ & 0.0049 & 0.0130 & $-0.0410^{*}$ & $-0.0257^{*}$ & -0.0223 & $0.0362^{*}$ & 0.0108 & 1.0000 & & & 1.08 \\
\hline PROBANKF & $-0.3293^{*}$ & $0.0383^{*}$ & -0.0069 & -0.0008 & $0.1854^{\star}$ & $-0.4727^{*}$ & $0.6383^{*}$ & $-0.2362^{*}$ & $0.0987^{*}$ & 1.0000 & & 1.98 \\
\hline INFLUENCE & $-0.0962^{*}$ & -0.0047 & 0.0052 & $-0.0533^{*}$ & $0.5581^{*}$ & $-0.1045^{\star}$ & $0.0712^{*}$ & $-0.1719^{\star}$ & -0.0064 & $0.0427^{\star}$ & 1.0000 & 1.67 \\
\hline BIG4 & $-0.0670^{*}$ & $0.2055^{\star}$ & $0.3049^{*}$ & $-0.2870^{\star}$ & $0.2313^{*}$ & 0.0291 & $-0.0323^{*}$ & $0.0537^{*}$ & $0.0430^{*}$ & $-0.0413^{*}$ & $0.0413^{*}$ & 1.62 \\
\hline GENDER & $0.0321^{*}$ & $0.1074^{*}$ & $0.1452^{*}$ & $-0.1162^{*}$ & 0.0142 & $0.0333^{*}$ & -0.0106 & $0.0320^{*}$ & 0.0032 & -0.0159 & -0.0228 & 1.46 \\
\hline LANG & -0.0201 & $0.1198^{*}$ & $0.1778^{*}$ & $-0.1453^{\star}$ & $-0.0118^{\star}$ & 0.0093 & $-0.0259^{*}$ & -0.0019 & $0.0285^{\star}$ & $-0.0440^{\star}$ & -0.0014 & 1.31 \\
\hline$E X P$ & $0.0338^{*}$ & $-0.1722^{*}$ & $-0.1670^{\star}$ & $0.4243^{*}$ & $-0.1141^{*}$ & 0.0129 & -0.0135 & $0.0249^{*}$ & 0.0016 & $-0.0255^{\star}$ & $-0.0568^{*}$ & 1.49 \\
\hline FYE & -0.0038 & 0.0170 & 0.0104 & 0.0139 & -0.0115 & -0.0002 & -0.0039 & $-0.0374^{*}$ & -0.0176 & -0.0024 & 0.0036 & 1.09 \\
\hline$L I S T$ & -0.0238 & -0.0033 & -0.0016 & -0.0211 & $0.1145^{\star}$ & $-0.0259^{*}$ & 0.0096 & $-0.0805^{\star}$ & -0.0027 & 0.0023 & $0.2313^{*}$ & 1.13 \\
\hline & & & & & & & & & & \multicolumn{3}{|c|}{ (continued on next page) } \\
\hline
\end{tabular}

This table presents the correlation matrix. * significant at 0.01 level; $p$-values are two-tailed. See Appendix III for variable definitions. 


\begin{tabular}{|c|c|c|c|c|c|}
\hline & $\frac{\Delta}{0}$ & 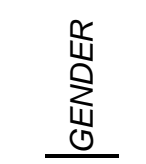 & 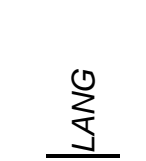 & 站 & 蓆 \\
\hline GENDER & $0.1353^{*}$ & 1.0000 & & & \\
\hline LANG & $0.0304^{*}$ & $0.0321^{*}$ & 1.0000 & & \\
\hline$E X P$ & $-0.4025^{\star}$ & $-0.1298^{*}$ & $-0.1669^{*}$ & 1.0000 & \\
\hline FYE & $-0.0274^{*}$ & -0.0050 & $0.0336^{*}$ & 0.0180 & 1.0000 \\
\hline LIST & 0.0050 & $0.0617^{*}$ & 0.0167 & $-0.0279^{*}$ & $0.0315^{\star}$ \\
\hline
\end{tabular}

This table presents the correlation matrix. ${ }^{*}$ significant at 0.01 level; $p$-values are two-tailed. See Appendix III for variable definitions. 
Table 4.5 reports the correlation matrices with significance levels reported at the 0.01 level. Most correlations are small, apart from some variables which by construction are correlated, like LOSS, ROA, PROBANKF, and OCF. The Variance Inflation Factors (VIF) do not exceed 3.12 which indicates that multicollinearity is not a concern.

\section{Regression Results}

Table 4.6 presents the regression results. The results show that HPS has a significant positive coefficient $(p=0.007)$, implying that auditors with higher neutral trait skepticism are more likely to issue a GCO to financially distressed clients. The coefficients of most of the control variables are in line with expectations. Specifically, we find that the coefficients of LNTA, CURRENT, and PROBANKF are significant negative, while LOSS significantly increases the likelihood of a GCO. When replacing HPS with $P M C$ and $R I T$, we find a positive coefficient for $P M C$ and a negative coefficient for RIT, both insignificant. However, when replacing the continuous measures of professional skepticism traits with dichotomous variables, we find significant associations for all professional skepticism traits. ${ }^{51}$ Specifically, untabulated results show a significant coefficient for HIGH_HPS (0.258; $\mathrm{t}=2.20 ; \mathrm{p}=0.028), H I G H \_P M C(0.368 ; \mathrm{t}=2.98 ; \mathrm{p}=0.003)$, and HIGH_RIT ($0.272 ; \mathrm{t}=-2.27 ; \mathrm{p}=0.023)$. These results further provide support for a significant positive relationship between auditor reporting decisions and the neutral (HPS) and professional moral courage $(P M C)$ trait skepticism. The results for $R I T$, however, suggest that presumptive doubt trait skepticism $(R I T)$ decreases the likelihood of a GCO. ${ }^{52}$

In terms of economic magnitude, the odds of receiving a GCO for clients with a partner with higher neutral trait skepticism (HIGH_HPS) were 1.3 times the odds of a company with a less skeptical audit partner and the odds of issuing a GCO for partners with higher moral courage (HIGH_PMC) were 1.4 times the odds of expressing a GCO for partners with a lower moral courage. Conversely, the odds of receiving a GCO for clients with a partner with high presumptive doubt trait skepticism (HIGH_RIT) was only 0.8 times the odds of a company with a more trusting partner. These are economically meaningful effects.

51 Dichotomizing variables relating to individual differences is rather common in accounting research (e.g., Gissel and Johnstone 2017; Pennington, Schafer, and Pinsker 2017; Sundgren and Svanström 2014; McAllister et al. 2018; Quadackers et al. 2014). Therefore, we rerun the analysis with PS as a dichotomous variable, indicating high or low trait skepticism (split based on the median score of HPS, PMC, and RIT). Previous research, however does not document a scale score that is indicative of high levels of trait skepticism. Although it is common practice to use the median as cut point, we acknowledge that this is somewhat arbitrary. Therefore, we also tested other cut points. We obtain similar inferences using alternative cut points (e.g., half a standard deviation above the mean).

52 In an untabulated analysis, we also examined the relationship on a subsample including only clients who received a GCO for the first time $(N=2,294)$. Results are very similar to the reported results of the full sample. We find a significant positive coefficient for HPS and a significant negative coefficient for RIT. 
Table 4.6 Regression Results

\begin{tabular}{|c|c|c|c|}
\hline Independent variables & Model with HPS & Model with $P M C$ & Model with $R I T$ \\
\hline HPS & $\begin{array}{l}0.012^{\star \star \star} \\
{[2.71]}\end{array}$ & & \\
\hline$P M C$ & & $\begin{array}{l}0.002 \\
{[0.32]}\end{array}$ & \\
\hline$R I T$ & & & $\begin{array}{l}-0.007 \\
{[-1.26]}\end{array}$ \\
\hline LNTA & $\begin{array}{l}-0.295^{* * *} \\
{[-7.40]}\end{array}$ & $\begin{array}{l}-0.294^{* * *} \\
{[-7.35]}\end{array}$ & $\begin{array}{l}-0.284^{* * *} \\
{[-7.25]}\end{array}$ \\
\hline LOSS & $\begin{array}{l}0.589^{* * *} \\
{[4.99]}\end{array}$ & $\begin{array}{l}0.574^{* * \star} \\
{[4.87]}\end{array}$ & $\begin{array}{l}0.527^{* * *} \\
{[4.51]}\end{array}$ \\
\hline$R O A$ & $\begin{array}{l}1.541^{\star \star \star} \\
{[4.10]}\end{array}$ & $\begin{array}{l}1.468^{* \star *} \\
{[3.90]}\end{array}$ & $\begin{array}{l}1.423^{\star \star *} \\
{[3.88]}\end{array}$ \\
\hline INVREC & $\begin{array}{l}0.157 \\
{[0.74]}\end{array}$ & $\begin{array}{l}0.207 \\
{[0.98]}\end{array}$ & $\begin{array}{l}0.226 \\
{[1.14]}\end{array}$ \\
\hline CURRENT & $\begin{array}{l}-0.043^{\star \star \star} \\
{[-3.09]}\end{array}$ & $\begin{array}{l}-0.044^{\star \star \star} \\
{[-3.10]}\end{array}$ & $\begin{array}{l}-0.045^{\star \star \star} \\
{[-3.21]}\end{array}$ \\
\hline PROBANKF & $\begin{array}{l}-13.92^{* * *} \\
{[-10.9]}\end{array}$ & $\begin{array}{l}-13.62^{* * *} \\
{[-10.8]}\end{array}$ & $\begin{array}{l}-13.58^{\star \star \star} \\
{[-11.3]}\end{array}$ \\
\hline INFLUENCE & $\begin{array}{l}0.094 \\
{[0.35]}\end{array}$ & $\begin{array}{l}0.080 \\
{[0.30]}\end{array}$ & $\begin{array}{l}0.049 \\
{[0.19]}\end{array}$ \\
\hline BIG4 & $\begin{array}{l}-0.343^{* \star} \\
{[-2.53]}\end{array}$ & $\begin{array}{l}-0.253^{\star} \\
{[-1.84]}\end{array}$ & $\begin{array}{l}-0.263^{* *} \\
{[-2.06]}\end{array}$ \\
\hline GENDER & $\begin{array}{l}0.164 \\
{[1.02]}\end{array}$ & $\begin{array}{l}0.204 \\
{[1.27]}\end{array}$ & $\begin{array}{l}0.221 \\
{[1.45]}\end{array}$ \\
\hline LANG & $\begin{array}{l}-0.316^{* *} \\
{[-2.35]}\end{array}$ & $\begin{array}{l}-0.244^{*} \\
{[-1.72]}\end{array}$ & $\begin{array}{l}-0.194 \\
{[-1.45]}\end{array}$ \\
\hline$E X P$ & $\begin{array}{l}-0.002 \\
{[-0.21]}\end{array}$ & $\begin{array}{l}-0.005 \\
{[-0.55]}\end{array}$ & $\begin{array}{l}0.004 \\
{[0.45]}\end{array}$ \\
\hline FYE & $\begin{array}{l}-0.093 \\
{[-0.55]}\end{array}$ & $\begin{array}{l}-0.104 \\
{[-0.62]}\end{array}$ & $\begin{array}{l}-0.149 \\
{[-0.92]}\end{array}$ \\
\hline LIST & $\begin{array}{l}0.037 \\
{[0.05]}\end{array}$ & $\begin{array}{l}0.075 \\
{[0.09]}\end{array}$ & $\begin{array}{l}0.076 \\
{[0.09]}\end{array}$ \\
\hline $\begin{array}{l}\text { IND_DUMMIES } \\
\text { YEAR_DUMMIES }\end{array}$ & $\begin{array}{l}\text { INCL. } \\
\text { INCL }\end{array}$ & INCL. & $\begin{array}{l}\text { INCL. } \\
\text { INCL }\end{array}$ \\
\hline Constant & $\begin{array}{l}6.023^{\star * \star} \\
{[4.39]}\end{array}$ & $\begin{array}{l}7.282^{\star * \star} \\
{[5.07]}\end{array}$ & $\begin{array}{l}7.815^{\star \star \star} \\
{[5.88]}\end{array}$ \\
\hline $\begin{array}{l}\mathrm{R}^{2} \\
\mathrm{~N}\end{array}$ & $\begin{array}{l}25.67 \% \\
4358\end{array}$ & $\begin{array}{l}25.32 \% \\
4331\end{array}$ & $\begin{array}{l}24.80 \% \\
4433\end{array}$ \\
\hline \multicolumn{4}{|c|}{$\begin{array}{l}{ }^{* *}{ }^{* *} \text { and }{ }^{* * *} \text { significant at } .10, .05 \text { and } .01 \text { level respectively. Variables are defined in Appendix III. } \\
\text { table reports the coefficients based on robust standard errors clustered at client firm level for } \\
\text { regression model: } \\
G C O_{i t}=\beta_{1}+\beta_{2} P S_{i t}+\beta_{3} L N T A_{i t}+\beta_{4} L O S S_{i t}+\beta_{5} R O A_{i t}+\beta_{6} I N V R E C_{i t}+B{ }_{7} C U R R E N T_{i t}+\beta \\
{ }_{8} P R O B A N K F_{i t}+\beta 9 I N F L U E N C E_{i t}+\beta_{10} B I G 4_{i t}+\beta_{11} G E N D E R_{i t}+\beta_{12} E X P E R I E N C E_{i t}+\beta{ }_{13} F Y E_{i t}+\beta \\
{ }_{14} L I S T_{i t}+\beta_{15} I N D U S T R Y_{i t}+\beta_{16} Y E A R_{i t}+\varepsilon_{i t}\end{array}$} \\
\hline
\end{tabular}




\subsection{ADDITIONAL ANALYSES}

To test whether trait skepticism plays a more important role in safeguarding audit quality in non-Big4 audit firms compared to Big4 audit firms, we estimate the regression models including an interaction term between HPS, PMC, RIT and BIG4. The level of professional skepticism might have a larger impact on the behavior of auditors of non-Big4 audit firms compared to Big 4 audit firms because the standard methodologies in Big 4 audit firms arguably contain stronger and stricter procedures, and Big 4 are likely to have more quality control checks in place. ${ }^{53}$ The results show, however, insignificant coefficients for the interaction terms. ${ }^{54}$

We also run the regression models including HPS, PMC, and RIT simultaneously. Quadackers et al. (2014) provide evidence that, in case of heightened audit risk (i.e., a client has a weak control environment), the RIT scale dominates the HPS scale in predicting auditor judgments (e.g., number of alternative error explanations considered) and actions (hours of audit effort budgeted). Quadackers et al. (2014) suggest that this indicates that the presumptive doubt perspective is particularly predictive of auditor decision making in higher-risk situations. The untabulated results, in contrast with the results of Quadackers et al. (2014), suggest that particularly neutral trait skepticism (HPS) is predictive for auditor decision making in terms of actual audit outcomes. This additional analysis provides further support for the positive association between neutral trait skepticism and the auditor's reporting behavior. There are a few possible explanations as to why our results differ from those reported by Quadackers et al. (2014). First, Quadackers et al. (2014) specifically focused on the control environment risk. They analyze HPS and RIT in separate regression models and always include interaction effects between the control environment risk and these trait variables. Therefore, we can only interpret their coefficients of HPS and RIT by taking into account the values of the control environment risk. Second, the highest score on the HPS scale (158) and the standard deviation (10.84) is much smaller in their sample than the highest score (175) and the standard deviation (13.43) in our sample. Third, the sample of Quadackers et al. (2014) potentially did not include a sufficient

53 We also run the analysis including an interaction effect with Big 6 audit firms. As a result of the global world in which businesses operate today, auditing has become a more global profession (Lenz and James, 2007). Nowadays, most audit firms are part of a global network of firms and DeAngelo's (1981) characterization of the large audit firm can be extended by viewing the audit firm in its entirety, i.e. the global audit firm network (Carson, 2009). The members of the network have the right to use the brand name, resources, methodologies, knowledge and expertise of the global network and in turn they are bound to abide by common policies and standards. Taking into account the membership requirements and obligations, the Second Tier firms potentially have a market-based incentive level similar to the Big 4 to supply uniform high-quality audits. The results show insignificant coefficients for the interaction terms.

54 In addition to regressions including the interaction terms, we also ran the regressions on split samples (Big 4 vs. non-Big 4). Our conclusion regarding the difference between Big 4 and non-Big 4 audit firms remains unchanged. 
number of auditors with a (relatively) high score on the HPS scale to find an effect of high neutral trait skepticism.

Lastly, we examine interaction effects between professional skepticism traits and situational characteristics. Since situational characteristics have the ability to restrict the expression of individual differences, individual differences (including personality traits) will matter less or not at all in function of situational strength (Cooper and Withney 2009; Meyer, Dalal and Hermida 2010). In strong situations (i.e., very high levels of risk), auditors may (be forced to) display similar behaviors (e.g., greatly extending audit testing in case of very high risk) regardless of their trait skepticism (e.g., Quadackers et al. 2014). Hence, auditor trait skepticism could be less important in strong situations because in such circumstances audit outcomes are more strongly affected by client characteristics (e.g., size, profitability). To test the effect of strong situations, we rerun the regression model including interaction effects between professional skepticism traits and situational characteristics (i.e., client size, client risk, partner workload, partner tenure). Overall, the untabulated results indicate that there are limited boundary effects of trait professional skepticism because there are not many cases where the effects of professional skepticism traits are being restricted by the situation. We find no significant interaction effects between HPS, PMC and RIT and client size, client risk and partner tenure. These results suggest that situations in auditing are perhaps not "strong" and that they provide ample room for personality to play its role. An exception is partner workload, for which we find negative interaction effects between partner workload (measured as dichotomous variables split at either the $90^{\text {th }}$ percentile of the number of clients audited or the $90^{\text {th }}$ percentile of the audited assets) and HPS and PMC. These results indicate that high workload reduces the positive effects of HPS and PMC on the likelihood of issuing a GCO.

\subsection{CONCLUSIONS, LIMITATIONS AND DIRECTIONS FOR FUTURE RESEARCH}

This paper enhances our understanding of the relationship between audit partners' trait skepticism and the auditor's reporting behavior in practice. By combining pre-structured and handcollected archival data with survey data from a representative sample of audit partners, this paper helps generalizing and contextualizing the results from prior laboratory experiments on professional skepticism (e.g., Bowlin et al. 2015; Quadackers et al. 2014; Rose 2007). Our results show that clients of auditors with higher neutral trait skepticism are more likely to receive a GCO when they are financially distressed. Further, the results suggest weak support for a positive relationship between professional moral courage trait skepticism and the likelihood of issuing a 
GCO. Conversely, we find weak evidence that higher presumptive doubt trait skepticism decreases the likelihood of issuing a GCO. Further, we find that situational characteristics rarely influence the effects of professional skepticism traits on the likelihood of expressing a GCO.

This study contributes to the literature by providing evidence that professional skepticism is associated with outcomes indicative of audit quality, supporting the ability of relatively simple psychometric scales to measure professional skepticism, the persistence of professional skepticism traits, and the validity of prior theory hypothesizing a link between professional skepticism and audit outcomes. Prior experimental literature has provided mixed evidence that trait professional skepticism affects audit quality, possibly because professional skepticism measures are noisy, and may capture different underlying constructs. Prior research has not linked trait skepticism measures with archival data, in part because of an inability to relate trait measures to specific audits. Our unique data allows us to tie trait skepticism measures to audit outcomes. Further, we provide evidence that different measures of professional skepticism capture different distinct aspects. Lastly, evidence that neutral trait skepticism predicts significant variation in all audit quality outcomes we investigate, highlights the importance of professional skepticism as a driver of audit quality.

We note that these results should be interpreted with the following limitations in mind. First, we cannot completely rule out the possibility that our results are driven by omitted variable bias. Second, as in all audit partner studies, endogeneity could also be a concern because the matching between audit partners and their clients is unlikely to be random, creating uncertainty about whether results are due to audit partner or client characteristics (Lennox and Wu 2018). It seems, however, unlikely that this would explain our results. To the extent that audit partner's professional skepticism affects the audit partner allocation process, it would seem likely that more skeptical partners would be allocated to lower quality clients (e.g., riskier clients), not the other way around. Third, we measured professional skepticism at one specific point in time. Although personality traits are stable characteristics, they are not perfectly time-invariant and our measures of trait skepticism might thus not perfectly capture auditors' professional skepticism at the time of performing the audit.

Despite these limitations, our archival study provides a first step in complementing behavioral experimental research on the relationship between professional skepticism and auditor judgments and decision-making. Furthermore, our results are likely relevant for the auditing profession, audit standard-setters, and regulators. 
Our data are drawn from Belgian firms, which enables us to relate surveyed professional skepticism to outcomes of audits for particular signing partners. Other research likewise exploits differences in financial-reporting regimes to shed light on questions of broad importance. As signing partners can now also be identified in other countries including the U.S., future research might seek to replicate our study by surveying partners in other countries and relating measurements of their professional skepticism to audit outcomes. Future research is also warranted on improving our understanding of how professional skepticism affects the audit process. 


\section{Chapter 5. GENERAL DISCUSSION}

\subsection{CONCLUSIONS}

The objective of this dissertation is to advance our understanding of professional skepticism by investigating professional skepticism as an input factor, and a driver of process and output factors to audit quality. In this dissertation, professional skepticism is conceptualized as a combination of personal (e.g., personality traits, and individual differences) and situational characteristics (e.g., tone at the top, budget pressure, and audit firm culture), that is, it can be understood as both a trait and state concept. To investigate the importance of inherent professional skepticism, the focus of this dissertation is on professional skepticism traits. However, to enable the distinction of the effect of trait and state skepticism, personal and situational characteristics are considered simultaneously.

\section{Input Factors}

The results, reported in Chapter 2, suggest that professional skepticism indeed is an important input factor to support a quality audit. First, the findings show that professional skepticism traits of auditors are significantly affected by personality traits and other individual differences and differ significantly across ranks. The auditor's personality (conscientiousness, openness, narcissism, and psychopathy), gender, and audit knowledge appear to be predictive of neutral and moral courage trait skepticism. Further, neutral and moral courage trait skepticism are positively associated with attitudes about behaving skeptically, subjective norms with respect to the social pressure to behave skeptically, and perceived behavioral control to behave skeptically, which in turn are positively associated with skeptical intentions. Lastly, the results suggest that these input factors (skeptical traits, attitudes, and intentions) ultimately affect audit quality as the study reports positive associations between these input factors and skeptical actions with respect to evidence collection and evaluation.

\section{Process Factors}

Chapter 3 of this dissertation, relating to process factors, explores whether professional skepticism is a driver of fraud brainstorming quality. The identification of fraud risk is an important part of the audit process and audit standards require the exercise of professional skepticism, especially when considering the risk of material misstatements due to fraud. The findings show positive associations between neutral and moral courage trait skepticism of partners and fraud 
brainstorming quality. The results suggest that partners with higher neutral trait skepticism, and especially with higher moral courage trait skepticism, will deliver higher fraud brainstorming quality, which indirectly will lead to higher audit quality.

\section{Output Factors}

To explore professional skepticism as a driver of audit outcomes, this dissertation examines whether professional skepticism traits of partners are predictive of actual audit quality outcomes as revealed by audit opinions. The findings, reported in Chapter 4, show that partners with higher neutral trait skepticism are more likely to issue a GCO. Further, the results weakly support a positive relation between partner's professional moral courage and the likelihood of expressing a GCO. Conversely, the results provide weak evidence that higher presumptive doubt trait skepticism decreases the likelihood of issuing a GCO. These findings appear to be economically meaningful.

\section{General Conclusions}

Overall, the findings of the different studies suggest that the inherent professional skepticism of an auditor is an important input factor to a quality audit, and a key driver for high quality audit processes and outcomes. Based on prior literature, different scales (HPS, RIT, and PMC) were used to capture professional skepticism traits. The results suggest that if an auditor is more professionally skeptical (HPS) and has more moral courage (PMC), the fraud brainstorming session will be of higher quality. As a higher fraud brainstorming quality leads to better fraud risk identification and more effective audit plans to identify misstatements due to fraud, higher fraud brainstorming quality will likely increase the quality of the audit. Further, a more professionally skeptical (HPS) and more professionally courageous (PMC) auditor has a positive effect on the likelihood of expressing a GCO. However, the findings provide evidence for a reverse relation with presumptive doubt trait skepticism $(R I T)$. These results suggest that the Hurtt Professional Skepticism Scale and the Professional Moral Courage Scale are more reliable measures of auditors professional skepticism traits compared to the inverse of the Rotter Interpersonal Trust Scale. The IAASB (2014) already argued that a degree of trust is essential in the audit process, and the findings of recent literature support this conclusion. Knechel et al. (2020) argue that trust is an important aspect in the audit process which can contribute to the independence of the auditor. Further, Aschauer et al. (2017) suggest that trust between auditors and clients enhances professional skepticism. 


\subsection{CONTRIBUTIONS AND PRACTICAL IMPLICATIONS}

This dissertation provides several incremental contributions to prior literature, as discussed in the previous chapters.

In general, our understanding of professional skepticism is advanced as these studies provide a holistic understanding of professional skepticism by simultaneously incorporating personal and situational characteristics. This approach enables the distinction between the effect of trait and state skepticism, in contrast to prior empirical research on professional skepticism which often focuses on singular relations in isolation (e.g., the importance of a partner's emphasis on skepticism with respect to fraud risk identification, fraud risk assessment, and fraud risk responses [Carpenter and Reimers 2013], the effect of partner communications on auditor professional skepticism [Harding and Trotman 2017], partner characteristics on the likelihood that audit team members will speak up and raise audit issues [Nelson et al. 2016]). Further, this approach (i.e., examining the effect sizes of given associations, while controlling for other relevant factors of professional skepticism) facilitates providing recommendations for practice. First, our overall results suggest that the inherent professional skepticism of an auditor affects the attitude and intention towards skeptical behavior, and consequently the audit processes and outcomes. Further, the findings show that these traits are affected by personality and individual differences. This speaks to the importance of finding the right personality fit for the profession. Hence, personality assessment during personnel screening and selection (e.g., by the use of personality tests) is recommended to ultimately attract and retain professionals that are able to take skeptical actions as the standards and regulators require. Second, the analyses include situational characteristics and these results could assist with designing effective interventions to improve auditors' (state) professional skepticism. The findings show that subjective norms (i.e., social pressure) are the strongest predictor of auditors' intentions to act skeptically. Subjective norms relate to how individuals feel about and respond to pressure from others. Furthermore, the results suggest that the effect of professional skepticism traits on the audit process (i.e., fraud brainstorming) is positive in audit firms with a positive performance evaluation system. Evidence of a positive performance evaluation system enhancing the exercise of professional skepticism is in line with Brazel et al. (2016) who found that the outcome of the audit process biases the supervisor's evaluations of skeptical behavior (i.e., auditors who employ an appropriate level of skepticism but do not identify a misstatement are penalized by the supervisors). Thus, based on the findings of this dissertation, it is recommended to focus the interventions on subjective norms (i.e., social pressure) and improving evaluation and reward systems, to enhance the exercise of 
professional skepticism. Next, based on the insights regarding fraud brainstorming quality and the underlying items across professional skepticism traits partitions, a high attendance rate of specialists, a high contribution of all team members, especially forensic specialists, and an extensive discussion about how management might perpetrate fraud during the fraud brainstorming session is recommended.

Finally, this dissertation contributes to the literature by providing evidence that the different measures of professional skepticism used in the literature capture distinct aspects. The results support the ability of relatively simple psychometric scales to measure professional skepticism, specifically the Hurtt Professional Skepticism Scale and the Professional Moral Courage Scale. However, the results reveal less support for using Rotter's Interpersonal Trust scale which appears to represent a distinct construct in our setting focusing on skeptical intentions and actions.

\subsection{LIMITATIONS AND DIRECTIONS FOR FUTURE RESEARCH}

The results of this dissertation should be interpreted with the limitations, as discussed in previous chapters, in mind.

Overall, in this dissertation, professional skepticism is measured at the individual auditor level. However, the audit is conducted by the audit engagement team, so auditors do not operate individually. It remains unknown to which extent different individuals within the audit team affect professional skepticism on the overall audit engagement. Especially the results of Chapter 3 and Chapter 4, where the inherent professional skepticism of the partner is tested, should therefore be interpreted with this limitation in mind. An important avenue for future research is to examine audit teams and audit team composition. We currently do not know whether it is necessary for all members to maintain professional skepticism or how teams are composed. For example, do partners with higher professional skepticism traits work with skeptical audit team members or not? Literature suggests that the individual characteristics of group members, as well as the diversity of skills and traits within a group, are important factors related to group effectiveness (Shaw 1981).

Further, the results in this dissertation suggest that professional skepticism is a driver for fraud brainstorming quality, an important part of the audit process. However, due to limited data availability, it is unclear whether other elements of the audit process are also affected by professional skepticism and how professional skepticism affects these processes. An important avenue for future research might be to explore whether professional skepticism affects materiality 
levels, audit planning, risk identification, risk assessment, audit testing, and the evaluation of identified material misstatements.

Last, the data in this dissertation are drawn from Belgian and Dutch audit firms. Belgium and the Netherlands are typical societies where individual views and approaches are valued which might encourage professional skepticism. However, in other cultures, individuals might be more likely to adhere to group norms and processes which might result in lower variation in skeptical behavior (IAASB 2014). Future research might seek to replicate our studies by surveying partners in other countries in order to investigate the effect of cultural differences on the association between professional skepticism and audit quality. 



\section{REFERENCES}

American Institue of Certified Public Accountants (AICPA). 1997. Consideration of fraud in a financial statement audit. New York, NY: AICPA.

Aobdia, D. 2019. Why Shouldn't Higher-IQ Audit Partners Deliver Better Auditrs? A Discussion of "IQ and Audit Quality: Do Smarter Auditors Deliver Better Audits?". Contemporary Accounting Research 36(3): 1404-1406.

Ajzen, I. 1991. The Theory of Planned Behavior. Organizational Behavior and Human Decision Processes 50 (2): 179-211.

Ajzen, I. 2005. Attitudes, Personality and Behavior $2^{\text {nd }}$ Edition. Open University Press. McGrawHill Education Europe, Berkshire, United Kingdom.

Ajzen, I. 2006. Constructing a theory of planned behavior questionnaire. Available online at: https://www.researchgate.net/publication/235913732_Constructing_a_Theory_of_Planned_B ehavior_Questionnaire.

Ajzen, I. 2012. The theory of planned behavior. In Handbook of theories of social psychology, edited by P. A. M. Lange, A. W. Kruglanski, and E. T. Higgins, 1: 438- 459. London, UK: Sage.

Anderson, S., and J. Wolfe. 2002. A perspective on audit malpractice claims. Journal of Accountancy 194(3): 59-66.

Armitage, C.J., and M. Conner. 1999. The theory of planned behavior: Assessment of predictive validity and perceived control. British Journal of Social Psychology 38 (1): 35-54.

Armitage, C.J., and M. Conner. 2001. Efficacy of the theory of planned behavior: Meta-analytic review. British Journal of Social Psychology 40 (4): 471-499.

Aschauer, E., M. Fink, A. Moro, K. van Bakel-Auer, and B. Warming-Rasmussen. 2017. Trust and professional skepticism in the relationship between auditors and clients: Overcoming the dichotomy myth. Behavioral Research in Accounting 29 (1): 19-42.

Autoriteit Financiële Markten (AFM) 2010. Rapport Algemene Bevindingen Kwaliteit Accountantscontrole en Kwaliteitsorganisaties. Amsterdam, The Netherlands: AFM.

Autoriteit Financiële Markten (AFM) 2014. Uitkomsten onderzoek kwaliteit wettelijke controles Big 4-accountantsorganisaties. Amsterdam, The Netherlands: AFM.

Autoriteit Financiële Markten (AFM) 2017. Uitkomsten van onderzoeken naar de implementatie en borging van verandertrajecten bij de $O O B$-accountantsorganisaties en de kwaliteit van de wettelijke controles bij de Big4-accountantsorganisaties. Amsterdam, The Netherlands: AFM.

Autoriteit Financiële Markten (AFM) 2018. Fraud Protocol: What can you expect from auditors when it comes to fraud. Amsterdam, The Netherlands: AFM. 
Autoriteit Financiële Markten (AFM) 2019. Kwaliteit overige OOB-accountantsorganisaties onderzocht. Uitkomsten van het onderzoek bij de overige OOB-accountantsorganisatie. Amsterdam, The Netherlands: AFM.

Bagley, P.L., D. Dalton, and M. Ortegren. 2012. The factors that affect accountants' decisions to seek careers with Big 4 versus non-Big 4 accounting firms. Accounting Horizons 26 (2): 239264.

Bailey, C.D. 2015. Psychopathy, academic accountants' attitudes toward unethical research practices, and publication success. The Accounting Review 90(4): 1307-1332.

Bamber, E.M., and M.V. Iyer. 2002. Big 5 auditors' professional and organizational identification: consistency or conflict? Auditing: A Journal of Practice and Theory 21(2): 21-38.

Bamber, E.M., and M.V. Iyer. 2007. Auditors' identification with their clients and its effect on auditors' objectivity. Auditing: A Journal of Practice and Theory 26(2): 1-24.

Bandura, A. 1977. Self-efficacy: Toward a unifying theory of behavioral change. Psychological Review 84: 191-215.

Bandura, A. 1982. Self-efficacy mechanism in human agency. American Psychologist 37(2): 122147.

Baumeister, R.F., and J.A. Bargh. 2014. Conscious and unconscious: Toward an integrative understanding of human mental life and action. In Dual-process theories of the social mind, edited by J.W. Sherman, B. Gawronski, and Y. Trope, 35-49. New York, NY, US: Guilford Press.

Beasley, M.S., J.V. Carcello, and D.R. Hermanson. 2001. Top 10 audit decisions. Journal of Accountancy 191(4): 63-66.

Beasley, M.S., J.V. Carcello, D.R. Hermanson, and T.L. Neal. 2013. An analysis of alleged auditor deficiencies in SEC fraud investigations:1998-2010. Center for Audit Quality.

Beasley, M., and J.G. Jenkins. 2003. A primer for brainstorming fraud risks. Journal of Accountancy 196(6): 8-32.

Bedard, J.C., M.L. Ettredge, and K.M. Johnstone. 2008. Fee pressure and the longitudinal dynamics of audit engagement budgeting and reporting. Advances in Accounting 24: 32-40.

Behling, O., and K.S. Law. 2000. Translating Questionnaires and Other Research Instruments: Problems and Solutions. Sage Publications.

Bell, T.B., M.E. Peecher, and I. Solomon. 2005. The 21st century public company audit: Conceptual elements of KPMG's global audit methodology. New York: KPMG LLP.

Bellovary, J.L., and K.M. Johnstone. 2007. Descriptive Evidence from Audit Practice on SAS No. 99 Brainstorming Activities. Current Issues in Auditing 1(1): 1-11. 
Bhaskar, L.S., T.M. Majors, and A. Vitalis. 2016. Are 'Good' Auditors Impacted More by Depletion? Threats to Valued Auditor Attributes. Working paper. Indiana University, University of Southern California, and University of Waterloo.

Bloomberg, R., M.W. Nelson, and E. Soltes. 2016. Gathering data for archival, field, survey, and experimental accounting research. Journal of Accounting Research 54 (2): 341-395.

Bobek, D.D., and R.C. Hatfield. 2003. An investigation of the theory of planned behavior and the role of moral obligation in tax compliance. Behavioral Research in Accounting 15(1): 13-38.

Bonner, S. 1990. Experience effects in auditing: The role of task-specific knowledge. The Accounting Review 65(1): 72-92.

Book, A., B.A. Viser, and A.A. Volk. 2015. Unpacking "evil": Claiming the core of the Dark Triad. Personality and Individual Differences 73: 29-38.

Bowlin, K.O., J.L. Hobson, and M.D. Piercey. 2015. The effects of auditor rotation, professional skepticism, and interactions with managers on audit quality. The Accounting Review 90(4): 1363-1393.

Brazel, J., T.D. Carpenter, and G.J. Jenkins. 2010. Auditors' Use of Brainstorming in the Consideration of Fraud: Reports from the Field. The Accounting Review 85(4): 1273-1301.

Brazel, J., S.B. Jackson, T.J. Schaefer, and B.W. Stewart. 2016. The outcome effect and professional skepticism. The Accounting Review 91 (6): 1577-1599.

Brazel, J., and T.J. Schaefer. 2015. Executive Summary: State of the Art Research Related to Auditor Professional Skepcitism. Available at: https://www.iaasb.org/system/files/meetings/files/20151207-IAASB-Agenda_Item_7BExecutive-Summary-State_of_Art_Research_Related_to_Auditor_Professional_Skepticismfinal_0.pdf

Brown, V.R., and P.B. Paulus. 2002. Making Group Brainstorming More Effective: Recommendations From an Associative Memory Perspective. Current Directions in Psychological Science 11(6): 208-212.

Buchan, H. F. 2005. Ethical decision making in the public accounting profession: An extension of Ajzen's Theory of Planned Behavior. Journal of Business Ethics 61: 165-181.

Carcello, J.V., A. Vanstraelen, and M. Willenborg. 2009. Rules Rather than Discretion in Audit Standards: Going Concern Opinions in Belgium. The Accounting Review 84(5): 1395-1428.

Carmichael, D.R., and J.L. Craig. 1996. Proposal to say the "F" word in auditing standards. The CPA Journal 66(6):22.

Carpenter, T.D. 2007. Audit team brainstorming, fraud risk identification, and fraud risk assessment: Implications of SAS No. 99. The Accounting Review 82(5): 1119-1140. 
Carpenter, T.D., and J.L. Reimers. 2005. Unethical and fraudulent financial reporting: Applying the theory of planned behavior. Journal of Business Ethics 60: 115-129.

Carpenter, T.D., and J.L. Reimers. 2013. Professional skepticism: The effects of a partner's influence and the level of fraud indicators on auditors' fraud judgments and actions. Behavioral Research in Accounting 25(2): 45-69.

Carson, E. 2009. Industry Specialization by global Audit. The Accounting Review 84(2): 355-382.

Causholli, M., M. De Martinis, D. Hay, and R. Knechel. 2010. Audit Markets, Fees and Production: Towards an Integrated View of Empirical Audit Research. Journal of Accounting Literature 29: 167-215.

Chen, Q., K. Kelly, and S. Salterio. 2012. Do changes in audit actions and attitudes consistent with increased auditor skepticism deter aggressive earnings management? An experimental investigation. Accounting, Organizations, and Society 37(2): 95-115.

Chen, X.C., K.T. Trotman, and F.H. Zhou. 2015. Nominal versus interacting electronic fraud brainstorming in hierarchical audit teams. The Accounting Review 90(1): 175-198.

Chi, W., L.A. Myers, T.C. Omer, and H. Xie. 2017. The effects of audit partner pre-client and client-specific experience on audit quality and on perceptions of audit quality. Review of Accounting Studies 22(1): 361-391.

Christ, M.Y. 1993. Evidence on the nature of audit planning problem representations: An examination of auditor free recalls. The Accounting Review 68(2): 304-322.

Choo, F. and K. Tan. 2000. Instruction, skepticism, and accounting students' ability to detect frauds in auditing. The Journal of Business Education 1(Fall): 72-87.

Craswell, A., D. Stokes, and J. Laughton. 2002. Auditor independence and fee dependence. Journal of Accounting and Economics 33(2): 253-275.

Church, B.W., N.T. Dai; X. Kuang and X. Liu. 2019. The role of auditor narcissism in auditor-client negotiations: Evidence from China. Contemporary Accounting Research, forthcoming.

Cohen, J.R., D.W. Dalton, and N.L. Harp. 2017. Neutral and presumptive doubt perspectives of professional skepticism and auditor job outcomes. Accounting, Organizations and Society 62 : $1-20$.

Cooper, W.H., and M.J. Withney. 2009. The Strong Situation Hypothesis. Personality and Social Psychology Review 13(1): 62-72.

Costa, P.T., and R.R. McCrae. 1992. Revised NEO Personality Inventory (NEO PI-R) and NEO Five-Factor Inventory (NEO-FFI): Professional manual. Odessa, FL: Psychological Assessment Resources. 
Dalton, D.W., S. Buchheit, and J.J. McMillan. 2014. Audit and tax career paths in public accounting: An analysis of student and professional perceptions. Accounting Horizons 28(2): 213-231.

DeAngelo, L.E. 1981. Auditor Size and Audit Quality. Journal of Accounting and Economics 3: 183-199.

Defond, M.L., K. Raghunandan, and K.R. Subramanyam. 2002. De nonaudit service fees impair auditor independence? Evidence from going-concern audit opinions. Journal of Accounting Research 40(4): 1247-1274.

DeFond, M.L., and J. Zhang. 2014. A review of archival auditing research. Journal of Accounting and Economics 58(2): 275-326.

Dennis, S.A., and K.M. Johnstone. 2016. A Field Survey of Contemporary Brainstorming Practices. Accounting Horizons 30(4): 449-472.

Dennis, S.A., and K.M. Johnstone. 2018. A field experiment examining audit subordinates' knowledge and a partner-led intervention in fraud brainstorming. Accounting, Organizations and Society 66: 14-28.

Dowling, C. 2009. Appropriate audit support system use: The influence of auditor, audit team, and firm factors. The Accounting Review 84(3): 771-810.

Drobyshevsky, A., S. B. Baumann, and W. Schneider. 2006. A rapid fMRI task battery for mapping of visual, motor, cognitive, and emotional function. Neuroimage 31(2): 732-744.

Ehrhart, M.G., K.H. Ehrhart, S.C. Roesch, B.G. Chung-Herrera, K. Nadler and K. Bradshaw. 2009. Testing the latent factor structure and construct validity of the Ten-Item Personality Inventory. Personality and Individual Differences 47: 900-905.

Epstein, S. 1979. The stability of behavior: I. On predicting most of the people much of the time. Journal of Personality and Social Psychology 37(7): 1097-1126.

Ericsson, K.A., and H.A. Simon. 1980. Verbal reports as data. Psychological Review 87(3): 215251.

Ettredge, M.L., J.C. Bedard, and K.M. Johnstone. 2008. Empirical tests of audit budget dynamics. Behavioral Research in Accounting 20(2): 1-18.

Eysenck, H.J. 1991. Dimensions of personality: 16, 5, or 3 ? - Criteria for a taxonomic paradigm. Personality and Individual Differences 12(8): 773-790.

Farag, M.S., and R.Z. Elias. 2016. The relationships between accounting students' personality, professional skepticism, and anticipatory socialization. Accounting Education 25(2): 124-138. 
Feng, M., and C. Li. 2014. Are Auditors Professionally Skeptical? Evidence from Auditors' GoingConcern Opinions and Management Earnings Forecasts. Journal of Accounting Research 52(5): 1061-1085.

Ferguson, L. 2015, March 3. Opening Statement on the International Forum of Independent Audit Regulators Report on 2014 Survey of Inspection Findings. Available at: https://www.ifiar.org/?wpdmdl=2070

Financial Reporting Council (FRC). 2012. Professional skepticism establishing a common understanding and reaffirming its central role in delivering audit quality. Londen: FRC.

Fishbein, M. and I. Azjen. 1975. Belief, Attitude, Intention and Behavior: An Introduction to Theory and Reserch. Addison Wesley: Reading, MA.

Fishbein, M., and I. Azjen. 2010. Predicting and Changing Behavior: The Reasoned Action Approach. Psychology Press (Taylor and Francis): New York.

Flanagen, J.C. 1954. The Critical Incident Technique. Psychological Bulleting 51(4): 327-358.

Fleeson, W. 2017. The production mechanisms of traits: Reflections on two amazing decades. Journal of Research in Personality 69: 4-12.

Fleeson, W., and P. Gallagher. 2009. The Implications of Big Five standing for the distribution of trait manifestation in behavior: Fifteen experience-sampling studies and a meta-analysis. Journal of Personality and Social Psychology 7(6): 1097-1114.

Francis, J.R. 2011. A framework for understanding and researching audit quality. Auditing: $A$ Journal of Practice and Theory 30(2): 125-152.

Francis, J.R., and M.D. Yu. 2009. Big 4 office size and audit quality. The Accounting Review 84 (5): 1521-52.

Fullerton, R., and C. Durtschi. 2004. The Effect of Professional Skepticism on the Fraud Detection Skills of Internal Auditors.

Gaeremynck, A., and M. Willekens. 2003. The endogenous relationship between audit-report type and business termination: evidence on private firms in a non-litigious environment. Accounting \& Business Research 33(1): 65-79.

General Accounting Office (GAO). 1996. The Accounting Profession. Major issues: progress and concerns. Washington D.C.

Gibbins, M., S. Salterio, and A. Webb. 2001. Evidence about auditor-client management negotiation concerning client's financial reporting. Journal of Accounting Research 39(3): 535563.

Gibbins, M., and K.T. Trotman. 2002. Audit review: Managers' interpersonal expectations and conduct of review. Contemporary Accounting Research 19(3): 411-444. 
Gibbins, M., and S. Qu. 2005. Eliciting experts' context knowledge with theory-based experiential questionnaires. Behavioral Research in Accounting 17(1): 71-88.

Gibson, A.M., and A.H. Frakes. 1997. Truth or consequences: A study of critical issues and decision making in accounting. Journal of Business Ethics 16(2): 161-171.

Gissel, J.L., and K.M. Johnstone. 2017. Information Sharing During Auditors' Fraud Brainstorming: Effects of Psychological Safety and Auditor Knowledge. Auditing: A Journal of Practice and Theory 36(2): 87-110.

Global Public Policy Committee (GPPC). 2013. Enhancing Auditor Professional Skepticism. By Glover, S., D. Prawitt, and B. Young. IAASB

Glover, S.M. 1997. The influence of time pressure and accountability on auditors' processing of nondiagnostic information. Journal of Accounting Research 35: 213-227.

Glover, S.M., and D.F. Prawitt. 2014. Enhancing auditor professional skepticism: The professional skepticism continuum. Current Issues in Auditing 8(2): 1-10.

Gold, A., U. Gronewold, and S.E. Salterio. 2014. Error management in audit firms: error climate, type, and originator. The Accounting Review 89(1): 303-330.

Goldman, N., M. Harris, and T.C. Omer. 2019. Does task-specific knowledge improve audit quality: Evidence from audits of income tax accounts. Available at SSRN: https://ssrn.com/abstract=3049095 or http://dx.doi.org/10.2139/ssrn.3049095

Goodwin, J. and D. Wu. 2016. What is the relationship between audit partner busyness and audit quality? Contemporary Accounting Research 33: 341-377.

Gosling, S.D., P.J. Rentfrow, and W.B. Jr. Swann. 2003. A very brief measure of the Big-Five personality domains. Journal of Research in Personality 37: 504-528.

Graham, L., and J.C. Bedard. 2003. Fraud risk and audit planning. International Journal of Auditing 7(1): 55-70.

Grenier, J.H. 2017. Encouraging professional skepticism in the industry specialization era. Journal of Business Ethics 142(2): 241-256.

Griffith, E.E., J.S. Hammersley, K. Kadous and D. Young. 2015. Auditor mindsets and audits of complex estimates. Journal of Accounting Research 53(1): 49-77.

Grohnert, T., R.H.G. Meuwissen, and W.H. Gijselaers. 2018. Developing auditors' professional skepticism: the effect of workplace learning on audit quality. Working paper. Maastricht University.

Gronewold, U., and M. Donle. 2011. Organizational error climate and auditors' predispositions toward handling errors. Behavioral Research in Accounting 23(2): 69-92. 
Gul, F.A., W. Donghui, and Y. Zhifeng. 2013. Do individual auditors affect audit quality? Evidence from archival data. The Accounting Review 88(6): 1993-2023.

Hammersley, J.S. 2006. Pattern identification and industry-specialist auditors. The Accounting Review 81(2): 309-336.

Hammersley, J.S. 2011. A review and model of auditor judgments in fraud-related planning tasks. Auditing: A Journal of Practice and Theory 30: 101-128.

Hammersley, J.S., K.M. Johnstone, and K. Kadous. 2011. How do audit seniors respond to heightened fraud risk? Auditing: A Journal of Practice and Theory 30(3): 81-101.

Hardies, K. 2019. Personality, social norms, and sexual harassment in the workplace. Personality and Individual Differences 151(109496): 1-5.

Hardies, K., D. Breesch, and J. Branson. 2016. Do (fe)male auditors impair audit quality? Evidence from going-concern opinions. European Accounting Review 25(1): 7-34.

Hardies, K., M.L. Vandenhaute, and D. Breesch. 2018. An Analysis of Auditors' Going-Concern Reporting Accuracy in Private Firms. Accounting Horizons 32(4): 117-132.

Hardies, K., and S. Janssen. 2017. FAR research project: Professional skepticism: a trending concept in need of understanding. Maandblad voor Accountancy en Bedrijfseconomie 91(9): 274-280.

Harding, N., M. Azim, R. Jidin, and J. Muir. 2016. A consideration of literature on trust and distrust as they relate to auditor professional skepticism. Australian Accounting Review 78(26): 243254.

Harding, N., and K. Trotman. 2017. The effect of partner communications of fraud likelihood and skeptical orientation on auditors' professional skepticism. Auditing: A Journal of Practice and Theory 36(2): 111-131.

Harrison, A., J. Summers and B. Mennecke. 2018. The effects of the Dark Triad on unethical behavior. Journal of Business Ethics 153(1): 53-77.

Hasson, B. and W.R. Knechel. 2019. Getting from skeptical judgment to skeptical action: A field study of auditor behavior. Working paper. Florida Southern College and University of Florida. Heirman, W., M. Walrave, A. Vermeulen, K. Ponnet, H. Vandebosch, and K. Hardies. 2016. Applying the theory of planned behavior to adolescents' acceptance of online friendship requests sent by strangers. Telematics and Informatics 33(4): 1119-1129.

Hmieleski, K.M. and D.A. Lerner. 2016. The Dark Triad and nascent entrepreneurship: An examination of unproductive versus productive entrepreneurial motives. Journal of Small Business Management 54(S1): 7-32. 
Hobson, J.L., M.T. Stern, and A.F. Zimbelman. 2019. The Benefit of Mean Auditors: The Influence of Social Interaction and the Dark Triad on Unjustified Auditor Trust. Contemporary Accounting Research, forthcoming.

Hoffman, V.B., and M.F. Zimbelman. 2009. Do strategic reasoning and brainstorming help auditors change their standard audit procedures in response to fraud risk? The Accounting Review 84(3): 811-837.

Hurtt, R.K. 2010. Development of a scale to measure professional skepticism. Auditing: A Journal of Practice and Theory 29(1): 149-171.

Hurtt, R.K., H. Brown-Liburd, C.E. Earley, and G. Krishnamoorthy. 2013. Research on auditor professional skepticism: Literature synthesis and opportunities for future research. Auditing: $A$ Journal of Practice and Theory 32: 45-97.

Hurtt, R.K., M. Eining, and D. Plumlee. 2012. Linking professional skepticism to auditors' behaviors. Working paper. Baylor University and University of Utah.

Institute of Chartered Accountants in England and Wales (ICAEW) Audit and Assurance Faculty. 2018. Skepticism: The Practitioners' Take. Available at: https://www.icaew.com//media/corporate/files/technical/audit-and-assurance/audit-and-assurancefaculty/publications/others/scepticism-the-practitioners-take.ashx

International Auditing and Assurance Standards Board (IAASB). 1998. The auditor's responsibilities relating to fraud in an audit of financial statements. ISA 240. New York, NY: IFAC.

International Auditing and Assurance Standards Board (IAASB). 2012. Overall Objectives of the Independent Auditor and the Conduct of an Audit in Accordance with International Standards on Auditing. ISA 200. Ney York, NY: IFAC.

International Auditing and Assurance Standards Board (IAASB). 2014. A Framework for Audit Quality: Key Elements that Create an Environment for Audit Quality. New York, NY: IFAC.

International Auditing and Assurance Standards Board (IAASB). 2015. Enhancing Audit Quality in the Public Interest. A Focus on Professional Skepticism, Quality Control, and Group Audits. Ney York, NY: IFAC.

International Auditing and Assurance Standards Board (IAASB). 2016. The auditor's responsibility to consider fraud in an audit of financial statements. ISA 240. New York, NY: IFAC.

International Auditing and Assurance Standards Board (IAASB), International Ethics Standards Board for Accountants (IESBA), and International Accounting Education Standards Board (IAESB). 2017. Toward Enhanced Professional Skepticism. Observations of the IAASB- 
IAESB-IESBA Professional Skepticism Working Group. Available at: https://www.ifac.org/publications-resources/toward-enhanced-professional-skepticism-0 International Federation of Accountants (IFAC). 2008. Handbook of International Auditing, Assurance and Ethics Pronouncements.

International Federation of Accountants (IFAC). 2009a. International Standard on Auditing (ISA) 200: Overall objectives of the independent auditor and the conduct of an audit in accordance with international standards on auditing. New York: IFAC.

International Federation of Accountants (IFAC). 2009b. International Standard on Auditing (ISA) 240: The auditor's responsibilities relating to fraud in an audit of financial statements. New York: IFAC.

International Federation of Accountants (IFAC). 2009c. International Standard on Auditing (ISA) 315: Identifying and assessing the risks of material misstatement through understanding the entity and its environment. New York: IFAC.

International Forum of Independent Audit Regulators (IFIAR). 2012. Global Survey of Audit Inspection Findings. Available at: www.ifiar.org

International Forum of Independent Audit Regulators (IFIAR). 2014. Report on 2013 Survey of Inspection Findings. Amsterdam, The Netherlands: IFIAR.

International Forum of Independent Audit Regulators (IFIAR). 2015. Report on 2014 Survey of Inspection Findings. Amsterdam, The Netherlands: IFIAR.

International Forum of Independent Audit Regulators (IFIAR). 2016. Report on 2015 Survey of Inspection Findings. Amsterdam, The Netherlands: IFIAR.

International Forum of Independent Audit Regulators (IFIAR). 2017. Report on 2016 Survey of Inspection Findings. Amsterdam, The Netherlands: IFIAR.

International Forum of Independent Audit Regulators (IFIAR). 2018. Report on 2017 Survey of Inspection Findings. Amsterdam, The Netherlands: IFIAR.

International Forum of Independent Audit Regulators (IFIAR). 2019. Report on 2018 Survey of Inspection Findings. Amsterdam, The Netherlands: IFIAR.

International Forum of Independent Audit Regulators (IFIAR). 2020. Report on 2019 Survey of Inspection Findings. Amsterdam, The Netherlands: IFIAR.

Isaacs, K., N.P. Mota, J. Tsai, I. Harpaz-Rotem, J.M. Cook, P.D. Kirwin, J.H. Krystal, S.M. Southwick, and R.H. Pietrzak. 2017. Psychological resilience in U.S. military veterans: A 2year, nationally representative prospective cohort study. Journal of Psychiatric Research 84: 301-309. 
Ittonen K., E. Vähämaa and S. Vähämaa. 2013. Female auditors and accruals quality. Accounting Horizons 27(2): 205-228.

John, O.P., R.W. Robins and L.A. Pervin. 2008. Handbook of personality: Theory and research. New York, NY: Guilford Press.

Johnson, J.A. 2019. Calibrating personality self-report scores to acquaitance ratings. Personality and Individual Differences, forthcoming.

Johnstone, K.M., and J.C. Bedard. 2001. Engagement planning, bid pricing, and client response in the market for initial attest engagements. The Accounting Review 76(2): 199-220.

Johnstone, K.M., M.H. Sutton, and T.D. Warfield. 2001. Antecedents and consequences of independence risk: Framework for analysis. Accounting Horizons 15(1): 1-18.

Jones, D.N. and D.L. Paulhus. 2014. Introducing the Short Dark Triad (SD3): A brief measure of dark personality traits. Assessment 21(1): 28-41.

Judge, T.A., and R. Ilies. 2002. Relationship of personality to performance motivation: A metaanalytic review. Journal of Applied Psychology 87: 797-807.

Kallunki, J., J.P. Kallunki, L. Niemi, and H. Nilsson. 2019. IQ and Audit Quality: Do Smarter Auditors Deliver Better Audits? Contemporary Accounting Research 36(3): 1373-1416.

Kelley, T., and L. Margheim. 1990. The Impact of Time Budget Pressure, Personality, and Leadership Variables on Dysfunctional Auditor Behavior. Auditing: A Journal of Practice and Theory 9(2): 21-42.

Kerr, N.L., and R.S. Tindale. 2004. Group Performance and Decision Making. Annual Review of Psychology 55: 623-655.

Khan, J., and N. Harding. 2020. Facilitating the application of auditors' underlying skeptical disposition: The relationship between trait skepticism and basic human values. Accounting Research Journal 33 (1): 34-56.

Khelil, I., K. Hussainey, and H. Noubbigh. 2016. Audit committee - internal audit interaction and moral courage. Managerial Auditing Journal 31(4/5): 403-433.

Kidder, R.M. 2005. Moral Courage: Taking Action When Your Values are Put to the Test. William Morrow Publishing, New York.

Knapp, C.A., and M.C. Knapp. 2001. The effects of experience and explicit fraud risk assessment in detecting fraud with analytical procedures. Accounting, Organizations and Society 26: 2537.

Knechel, W.R., G.V. Krishnan, M. Pevzner, L.B. Shefchik, and U.K. Velury. 2013. Audit quality: Insights from the academic literature. Auditing: A Journal of Practice and Theory 32(S1): 385421. 
Knechel, W.R., A. Sofla and T. Svanström. 2015b. Recognition and Control of Professional Skepticism in Big 4 and Non-Big 4 Audit Firms. Working paper. University of Florida, KU Leuven, and Umea School of Business and Economics.

Knechel, W.R., E. Thomas, and M. Driskill. 2020. Understanding financial auditing from a service perspective. Accounting, Organizations and Society 81.

Knechel, W.R., and A. Vanstraelen. 2007. The Relationship between Auditor Tenure and Audit Quality Implied by Going Concern Opinions. Auditing: A Journal of Practice and Theory 26(1): 113-131.

Knechel, W.R., A. Vanstraelen, and M. Zerni. 2015a. Does the Identity of Engagement Partners

Matter? An Analysis of Audit Partner Reporting Decisions. Contemporary Accounting Research 32(4): 1443-1478.

Koch, K., K. Pauly, T. Kellermann, N.Y. Seiferth, M. Reske, V. Backes, and U. Habel. 2007. Gender differences in the cognitive control of emotion: An fMRI study. Neuropsychologia 45(12): 2744-2754.

KPMG. 2020. Practice aptitude tests online resources: https://www.practiceaptitudetests.com/top-employer-profiles/kpmg-assessments/

Kuhl, J., and M. Quirin. 2011. Seven steps toward freedom and two ways to lose it: Overcoming limitations of intentionality through self-confrontational coping with stress. Social Psychology 42(1): 74-84.

Landis, M., S.L. Jerris, and M. Braswell. 2008. Better Brainstorming. Journal of Accountancy 206(4): 70-73.

Lennox, C. and X. Wu. 2018. A review of the archival literature on audit partners. Accounting Horizons 32(2): 1-35.

Lenz, H., and L. James. 2007. International Audit Firms as Strategic Networks - The Evolution of Global Professional Service. In Economics and Management of Networks. Franchising, Strategic Alliances, and Cooperatives edited by G. Cliquet, M. Tuunane, G. Hendrikese, and J. Windsperger. Heidelberg: Physica-Verslag.

Libby, R., and J. Luft. 1993. Determinants of Judgement Performance in Accounting Settings: Ability, Knowledge, Motivation, and Environment. Accounting, Organizations and Society, 18(5): 425-250.

Lynch, A.L., U.S. Murthy, and T.J. Engle. 2009. Fraud brainstorming using computer-mediated communication: The effects of brainstorming technique and facilitation. The Accounting Review 84(4): 1209-1232. 
Majors, T. 2013. Communicating measurement uncertainty: An experimental study of financial reporting implications for managers and investors. Dissertation, University of Texas - Austin. Later published as: Majors, T. 2016. The interaction of communicating measurement uncertainty and the Dark Triad on managers' reporting decisions. The Accounting Review 91(3): 973-992.

Malone, C.F., and R.W. Roberts. 1996. Factors associated with the incidence of reduced audit quality behaviors. Auditing: A Journal of Practice and Theory 15(2): 49-64.

Marks, M.A., J.E. Mathieu, and S.J. Zaccaro. 2001. A temporally based framework taxonomy of team processes. Academy of Management Review 26(3): 356-376.

McAllister, M., A.D. Blay, and K. Kadous. 2018. Fraud Brainstorming Group Composition: The Persuasive Power of a Skeptical Minority. Working paper. Bryant University, Florida State University, and Emory University.

McCrae, R.R., and P.T. Costa. 1990. Personality in Adulthood. New York, NY: Guilford Press.

McCrae, R.R. and P.T. Costa. 1995. Trait explanations in personality psychology. European Journal of Personality 9(4): 231-252.

McKnight, D.H., V. Choudhury, and C. Kacmar. 2002. Developing and validating trust measures for e-commerce: An integrative typology. Information Systems Research 13(1): 334-359.

McKnight, D.H., C.J. Kacmar, and V. Choudhury. 2004. Dispositional trust and distrust distinctions in predicting high-risk and low-risk internet expert advice site perceptions. e-Service Journal $3(2): 35-58$.

McMillan, J.J., and R.A. White. 1993. Auditors' belief revisions and evidence search: the effect of hypothesis frame, confirmation bias, and professional skepticism. The Accounting Review 68(3): 443-465.

Mervielde I, F. De Fruyt, and S. Jarmuz. 1998. Linking openness and intellect in childhood and adulthood. In Parental Descriptions of Child Personality: Developmental Antecedents of the Big Five. Mahway, NJ: Erlbaum.

Meyer, R.D., R.S. Dalal, and R. Hermida. 2010. Review and Synthesis of Situational Strength in the Organizational Sciences. Journal of Management 36(1): 121-140.

Mock, T.J., and J.L. Turner. 2005. Auditor identification of fraud risk factors and their impact on audit programs. International Journal of Auditing 9(1): 59-77.

Mutchler, J., W. Hopwood, and J.C. McKeown. 1997. The Influence of Contrary Information and Mitigating Factors on Audit Opinion Decisions on Bankrupt Companies. Journal of Accounting Research 35(2): 295-310. 
Nelson, M.W. 2009. A model and literature review of professional skepticism in auditing. Auditing: A Journal of Practice and Theory 28(2): 1-34.

Nelson, M.W. and D.J. Skinner. 2013. How should we think about earnings quality? A discussion of: "Earnings quality: Evidence from the field". Journal of Accounting and Economics 56: 3441.

Nelson, M.W., C.A. Proell, and A.E. Randel. 2016. Team-oriented leadership and auditors' willingness to raise audit issues. The Accounting Review/ 91(6): 1781-1805.

Nelson, M.W., J.A. Eliott, and R.L. Tarpley. 2002. Evidence from auditors about managers' and auditors' earnings management decisions. The Accounting Review 77(Supplement): 175-202.

Nkansa, P. and C.D. Bailey. 2018. Survey Nonresponse in the Auditing Profession: Trends and Recommendations. Current Issues in Auditing 12(1): A7-A17.

Nolder, C.J., and K. Blankenship. 2019. Application of Attitude Research Across Domains: Current State of Knowledge and Future Directions. In Handbook of Attitudes edited by D. Albarracin, and B.T. Johnson. New York, NY, US: Routledge.

Nolder, C.J., and K. Kadous. 2018. Grounding the professional skepticism construct in mindset and attitude theory: A way forward. Accounting, Organizations and Society 67: 1-14.

Nolder, C.J., K. Kadous, and M.E. Peecher. 2019. The role of attitudes in auditing research and directions for future research. In Handbook of attitudes ( $2^{\text {nd }}$ ed.) edited by Albarracin, and Johnson. Londen: Routledge.

O'Boyle, E.H., D.R. Forsyth, G.C. Banks and M.A. McDaniel. 2012. A meta-analysis of the Dark Triad and work behavior: a social exchange perspective. Journal of Applied Psychology 97(3): 557-579.

O'Malley, S.F.C. 2000. The Panel on Audit Effectiveness. Stanford, CT: The Public Oversight Board.

Olsen, C., E. Brevik, A. Lundervold, and I. Stuart. 2017. What Personality Traits Make Auditors Professionally Skeptical? Opportunities for Future Research on Trait Professional Skepticism. Available at SSRN: https://ssrn.com/abstract=2618363

Olsen, C., and A. Gold. 2018. Future research directions at the intersection between cognitive neuroscience research and auditors' professional skepticism. Journal of Accounting Literature 41: 127-141.

Ooghe, H. and C. Spaenjers. 2005. De FiTO-meter: een nieuwe, eenvoudige en geïntegreerde maatstaf voor de financiële toestand van een onderneming. Accountancy en Bedrijfskunde 25(3): 5-14. 
Paulhus, D.L., and K. Williams. 2002. The Dark Triad of personality, narcissism, Machiavellianism, and psychopathy. Journal of Research in Personality 36: 556-563.

Payne, E.A., and R.J. Ramsay. 2005. Fraud risk assessments and auditors' professional skepticism. Managerial Auditing Journal 20(3): 321-330.

Peecher, M.E. 1996. The influence of auditors' justification processes on their decisions: A cognitive model and experimental evidence. Journal of Accounting Research 34(1): 125-140.

Pennington, R., J. Schafer, and R. Pinsker. 2017. Do Auditor Advocacy Attitudes Impede Audit Objectivity? Journal of Accounting, Auditing \& Finance 32(1): 136-151.

Ponemon, L.A. 1992. Auditor underreporting of time and moral reasoning: An experimental lab study. Contemporary Accounting Research 9(1): 171-189.

Popoola, T.I., and K.O. Akinyele. 2017. Professional Skepticism and Auditing. Accounting, Auditing and Accountability Journal 30(8): 1927-1928.

Popova, V. 2012. Exploration of skepticism, client-specific experiences, and audit judgments. Managerial Auditing Journal 28(2): 140-160.

Prusik, M., and M. Szulawski. 2019. The relationship between the Dark Triad personality traits, motivation at work, and burnout among HR recruitment workers. Frontiers in Psychology 10(1290): 1-12.

Public Company Accounting Oversight Board (PCAOB). 2003. Consideration of fraud in financial statement audits. Auditing Standard No. 2401. Washington, DC: PCAOB.

Public Company Accounting Oversight Board (PCAOB). 2006. Due professional care in the performance of work. Auditing Standard No. 1015. Washington, DC: PCAOB.

Public Company Accounting Oversight Board (PCAOB). 2008. Report on the PCAOB's 2004, 2005, 2006, and 2007 Inspections of Domestic Annually Inspected Firms. Washington, DC: PCAOB.

Public Company Accounting Oversight Board (PCAOB). 2012. Staff Audit Practice Alert on Maintaining and Applying Professional Skepticism in Audits. Washington, DC: PCAOB.

Public Company Accounting Oversight Board (PCAOB). 2015a. Concept Release on Audit Quality Indicators. Washington, DC: PCAOB.

Public Company Accounting Oversight Board (PCAOB). 2015b. Staff Inspection Brief. Vol.2015/2, October 2015. Washington, DC: PCAOB.

Public Company Accounting Oversight Board (PCAOB). 2016. Release No. 2016-004. Annual Report on the Interim Inspection Program Related to Audits of Brokers and Dealers. Washington, DC: PCAOB. 
Public Company Accounting Oversight Board (PCAOB). 2018. Release No. 2018-003. Annual Report on the Interim Inspection Program Related to Audits of Brokers and Dealers. Washington, DC: PCAOB.

Public Company Accounting Oversight Board (PCAOB). 2019a. Release No. 105-2019-031. Order instituting disciplinary proceedings, making findings, and imposing sanctions. Washington, DC: PCAOB.

Public Company Accounting Oversight Board (PCAOB). 2019b. Release No. 2019-002. Annual Report on the Interim Inspection Program Related to Audits of Brokers and Dealers. Washington, DC: PCAOB.

Quadackers, L., M. Groot, and A. Wright. 2009. Auditor's professional characteristics and their relationship to skeptical judgments and decisions. Working paper. Vrije Universiteit Amsterdam and Northeastern University.

Quadackers, L., M. Groot, and A. Wright. 2014. Auditor's professional skepticism: Neutrality versus presumptive doubt. Contemporary Accounting Research 31(3): 639-657.

Rasso, J.F. 2015. Construal instructions and professional skepticism in evaluating complex estimates. Accounting Organizations and Society 46: 44-55.

Rennie, M.E., L.S. Kopp, and W.M. Lemon. 2010. Exploring trust and the auditor-client relationship: Factors influencing the auditor's trust of a client representative. Auditing: $A$ Journal of Practice and Theory 29(1): 279-293.

Reynolds, K.J., and J.R. Francis. 2000. Does size matter? The influence of large clients on officelevel auditor reporting decisions. Journal of Accounting and Economics 30(3): 375-400.

Richards, L. 2016. Best practices for ensuring professional skepticism in the audit process. Available at http://www.accountingweb.com/aa/auditing/best-practices-for-ensuringprofessional-skepticism-in-the-audit-process.

Roberts, B.W., and W.F. DelVecchio. 2000. The rank-order consistency of personality traits from childhood to old age: A quantitative review of longitudinal studies. Psychological Bulletin 126(1): 3-25.

Robinson, D. 2008. Auditor independence and auditor-provided tax service: Evidence from goingconcern audit opinions prior to bankruptcy filings. Auditing: A Journal of Practice and Theory 27(2): 31-54.

Robinson, S., M.B. Curtis, and J.C. Robertson. 2018. Disentangling the Trait and State Components of Professional Skepticism: Specifying a Process for State Scale Development. Auditing: A Journal of Practice and Theory 37(1): 215-235. 
Romero, E., P.V.J.A. Gómez-Fraguela and L. López-Romero. 2012. Measuring personality traits with ultra-short scales: A study of the Ten Item Personality Inventory (TIPI) in a Spanish sample. Personality and Individual Differences 53: 289-293.

Rose, J.M. 2007. Attention to Evidence of Aggressive Financial Reporting and Intentional Misstatement Judgments: Effects of Experience and Trust. Behavioral Research In Accounting 19: 215-229.

Rotter, J.B. 1954. Social learning and clinical psychology. Englewood Cliffs, NJ: Prentice-Hall.

Rotter, J.B. 1967. A new scale for the measurement of interpersonal trust. Journal of Personality 35: 651-665.

Rouwelaar, J.B. and I. De Loo. 2018. The influence of management accountants on managerial decisions. Journal of Applied Accounting Research 19: 442-464.

Scott, B.A., J.A. Colquitt, E.L. Paddock, and T.A. Judge. 2010. A daily investigation of the role of manager empathy on employee well-being. Organizational Behavior and Human Decision Processes 113: 127-140.

Sekerka, L.E., and R.P. Bagozzi. 2007. Moral courage in the workplace: moving to and from the desire and decision to act. Business Ethics: A European Review 16(2): 132-149.

Sekerka, L.E., R.P. Bagozzi, and R. Charnigo. 2009. Facing ethical challenges in the workplace: Conceptualizing and measuring professional moral courage. Journal of Business Ethics 89(4): 565-579.

Shaub, M.K. 1996. Trust and suspicion: The effects of situational and dispositional factors on auditors' trust of clients. Behavioral Research in Accounting 8: 154-174.

Shaub, M.K., and J.E. Lawrence. 1999. Differences in auditors' professional skepticism across career levels in the firm. Advances in Accounting Behavioral Research 2: 61-83.

Sharma, D.S. 2014. Non-audit services and auditor independence. In Routledge Companion to Auditing, edited by D. Hay, W.R. Knechel, and M. Willekens, 67-88. New York, NY, US: Routledge.

Shaw, M.E. 1981. Group dynamics: The psychology of small group behavior. New York: McGrawHill.

Sheeran, P. 2002. Intention-Behavior Relations: A Conceptual and Empirical Review. European Review of Social Psychology 12(1): 1-36.

Srivastava, S., O.P. John, S.D. Gosling, and J. Potter. 2003. Development of personality in early and middle adulthood: Set like plaster or persistent change? Journal of Personality and Social Psychology 84(5): 1041-1053. 
Stevens, G.W., J.K. Deuling, and A.A. Armenakis. 2012. Successful psychopaths: Are they unethical decision-makers and why? Journal of Business Ethics 105: 139-149.

Sundgren, S. and S. Svanström. 2014. Auditor-in-charge characteristics and going-concern reporting. Contemporary Accounting Research 31(2): 531-550.

Sweeney, B., D. Arnold, and B. Pierce. 2010. The impact of perceived ethical culture of the firm and demographic variables on auditors' ethical evaluation and intention to act decisions. Journal of Business Ethics 93(4): 531-551.

Tabachnick, B.G. and L.S. Fidell. 2013. Using Multivarite Statistics. Boston: Pearson.

Trotman, K.T., T.D. Bauer, and K.A. Humphreys. 2015. Group judgement and decision making in auditing: Past and furture research. Accounting, Organizations and Society 47: 56-72.

Trotman, K.T., R. Simnett, and A. Khalifa. 2009. Impact of the type of audit team discussions on auditors' generation of material frauds. Contemporary Accounting Reseach 26(4): 1115-1142.

Van Linden, C., and K. Hardies. 2018. Entrance requirements to the audit profession within the EU and audit quality. International Journal of Auditing 22(3): 360-373.

Vedel, A. and D.K. Thomsen. 2017. The Dark Triad across academic majors. Personality and Individual Differences 116: 86-91.

Webb, T.L., and P. Sheeran. 2006. Does changing behavioral intentions engender behavior change? A meta-analysis of the experimental evidence. Psychological Bulletin 132(2): 249268.

Wissing, B.G., and M.A. Reinhard. 2019. The Dark Triad and deception perceptions. Frontiers in Psychology 10(1811): 1-7.

Wittek, R., T. van der Zee, and P. Mühlau. 2008. Client acceptance decisions of Dutch auditing parnters. Journal of Management and Governance 12: 93-115.

Wrightsman, L.S. 1991. Interpersonal Trust and Attitudes Toward Human Nature. In Measures of Personality and Social Psychological Attitudes edited by Robinson, J.P., P.R. Shaver and L.S. Wrightsman, 373-412. Volume 1 in Measures of Social Psychological Attitudes Series.

Ying, S.X., C. Patel, and P. Pan. 2019. Accounting and Business Research 50 (2): 179-202.

Zerni, M. 2012. Audit partner specialization and audit fees: Some evidence from Sweden. Contemporary Accounting Research 29(1): 312-340. 


\section{APPENDICES}

APPENDIX I. VARIABLES DEFINITIONS CHAPTER 2

\begin{tabular}{|c|c|}
\hline Variable Name & Description \\
\hline \multicolumn{2}{|c|}{ Professional Skepticism Traits } \\
\hline HPS & Auditor's score on the Hurtt Professional Skepticism Scale.* \\
\hline$P M C$ & Auditor's score on the Professional Moral Courage Scale.* \\
\hline$R I T$ & $\begin{array}{l}\text { Reversed auditor's score on the Rotter Interpersonal Trust } \\
\text { Scale.* }\end{array}$ \\
\hline \multicolumn{2}{|l|}{ Individual Differences } \\
\hline$A G E$ & The age of the auditor expressed in years. \\
\hline $\begin{array}{l}\text { AUDIT KNOWLEDGE } \\
\text { KNOW_VALUATION } \\
\text { KNOW_FRAUD } \\
\text { KNOW_ANALYT_PROC }\end{array}$ & $\begin{array}{l}\text { Measures of knowledge on a scale from } 1 \text { (not at all } \\
\text { experienced) to } 7 \text { (extremely experienced) relating to } \\
\text { measurement and valuation, risk of material misstatement } \\
\text { due to fraud, and the application of analytical procedures. }\end{array}$ \\
\hline EXPERIENCE_YRS & The experience of the auditor expressed in years. \\
\hline GENDER & $\begin{array}{l}\text { Dichotomous variables equal to } 1 \text { if the auditor is female; } 0 \\
\text { otherwise. }\end{array}$ \\
\hline \multicolumn{2}{|l|}{ Personality Traits } \\
\hline $\begin{array}{l}\text { DARK TRIAD MEASURES } \\
\text { MACHIAVELLIANISM } \\
\text { NARCISSISM } \\
\text { PSYCHOPATHY }\end{array}$ & $\begin{array}{l}\text { Jones and Paulhus (2014) measures of personality on a } \\
\text { scale from } 1 \text { (disagree strongly) to } 5 \text { (strongly agree); } \\
\text { measured as the mean score of the answers to the } \\
\text { underlying items. }\end{array}$ \\
\hline $\begin{array}{l}\text { PERSONALITY MEASURES } \\
\text { EXTRAVERSION } \\
\text { AGREEABLENESS } \\
\text { CONSCIENTIOUSNESS } \\
\text { EMOTIONALSTABILITY } \\
\text { OPENNESS }\end{array}$ & $\begin{array}{l}\text { Gosling et al (2003) measures of personality on a scale } \\
\text { from } 1 \text { (disagree strongly) to } 7 \text { (agree strongly); measured } \\
\text { as the mean score of the answers to the underlying items. }\end{array}$ \\
\hline \multicolumn{2}{|l|}{ Theory of Planned Behavior } \\
\hline ATTITUDE & $\begin{array}{l}\text { Measure of attitude towards professional skepticism on a } \\
\text { scale from } 1 \text { to } 7 \text { based on responses to five underlying } \\
\text { statements; author-constructed scale based on the work } \\
\text { of Ajzen }(1991 ; 2006) .{ }^{*}\end{array}$ \\
\hline INTENTION & $\begin{array}{l}\text { Measure of intention towards professional skepticism on a } \\
\text { scale from } 1 \text { (strongly disagree) to } 7 \text { (strongly agree); } \\
\text { measured by the answer to the question 'I intend to } \\
\text { maintain professional skepticism throughout my next } \\
\text { audits'; author-constructed scale based on the work of } \\
\text { Ajzen }(1991 ; 2006) \text {. }\end{array}$ \\
\hline
\end{tabular}




Variable Name
PERCEIVED_BEHAVIORAL_
CONTROL ( $\overline{P B C})$

SUBJECTIVE_NORM (SN)

\section{Situational Characteristics}

BIG4

BUDGET_PRESSURE

CLIENT_IMPORTANCE

TONE_AT_TOP

\section{Skeptical Actions}

SEARCHING_FOR_INFO

QUESTIONING

SUSPENDING_JDGMT
Description

Measure of self-control on a scale from 1 to 7 based on responses to three underlying statements; authorconstructed scale based on the work of Ajzen (1991; 2006). *

Measure of perceived social pressure on a scale from 1 to 7 based on responses to three underlying statements; author-constructed scale based on the work of Ajzen $(1991 ; 2006){ }^{*}$

Dichotomous variables equal to 1 if the audit firm is a Big4 firm; 0 otherwise.

Measure of time budget pressure on a scale from 1 (strongly disagree) to 7 (strongly agree); measured as the sum of the answers to the underlying 3 items. *

Measure of the importance of the client on a scale from 1 (not at all important) to 7 (extremely important).

Sweeney et al. (2010) measure of perceived unethical tone at the top on a scale from 1 (disagree strongly) to 7 (strongly agree); measured as the reverse of the sum of the answers to the underlying 4 items. ${ }^{*}$

Measures of skeptical action on a scale from 1 to 7 based on responses to three underlying statements; authorconstructed scale based on the work of Robinson et al. (2017).* 
APPENDIX II. VARIABLES DEFINITIONS CHAPTER 3

Variable Name

Professional Skepticism Traits

HPS

$P M C$

RITS

Fraud Brainstorming Quality

$F B Q$

AGENDA

ATT_[ALL_LVLS, FORENSIC,

IT, TAKS]

CONTR_[STAFF, SENIOR, MAN, PTR, FOREN]

DISCUSS_[MGT, RESP]

HOURS_PREP

LEADER PTR FS
Description

Auditor's score on the Hurtt Professional Skepticism Scale. * Auditor's score on the Professional Moral Courage Scale.*

Reversed auditor's score on the Rotter Interpersonal Trust Scale.*

Brazel et al. (2010) measure of fraud brainstorming quality; calculated as the sum of the answers to the underlying 21 items: LEADER_PTR_FS, ATT_[ALL_LVLS, FORENSIC, IT, TAX], CONTR_STAFF, SENIOR, MAN, PTR, FOREN], PTR_OPEN, AGENDA, NO_CHECKLIST, TIMING_PPEP, TIMING_END_PY, HOURS_PREP, SESSIONS_MULT, SESSIONS_DUR, LIST_PRIOR, DISCUSS_MGT, DISCUSS_RESP.

Dichotomous variables equal to 1 if an agenda was used during fraud brainstorming; 0 otherwise.

Dichotomous variables equal to 1 if the session was attended by [all levels of the engagement team, forensic specialist, IT specialist, tax professional]; 0 otherwise.

The relative levels of [staff, senior, manager, partner, forensic specialist] contribution to the session on a scale from 1 (very low contribution) to 7 (very high contribution); to measure fraud brainstorming quality, a dichotomous variable is created which is equal to 1 if the perceived level of contribution of the [staff, senior, manager, partner, forensic specialist] is greater than the sample mean; 0 otherwise.

The extent of discussion during the session about [how management might perpetrate fraud, audit responses to fraud risk] on a scale from 1 (no discussion at all) to 7 (extreme amount of discussion); to measure fraud brainstorming quality, a dichotomous variable is created which is equal to 1 if the extent of discussion is greater than the sample mean; 0 otherwise.

The hours spent by the engagement team preparing for fraud brainstorming; to measure fraud brainstorming quality, a dichotomous variable is created which is equal to 1 if the number of hours is greater than the sample mean; 0 otherwise.

Dichotomous variables equal to 1 if the session was led by the audit partner or a forensic specialist; 0 otherwise. 
Variable Name

LIST_PRIOR

NO_CHECKLIST

PTR_OPEN

SESSIONS_DUR

SESSIONS_MULT

TIMING_[PPEP, END_PY]

Control Variables

AUDITEXP_cat

BUDGETPRESSURE

CLIENTEXP

CLIENTIMPORTANCE

FRAUDDETECT

FRAUDEXP

MANAGERCHANGE
Description

Dichotomous variables equal to 1 if the participant developed a list of fraud risks prior to brainstorming with the group; 0 otherwise.

Dichotomous variables equal to 1 if no checklist was used during fraud brainstorming; 0 otherwise.

Participant's rating of the engagement partner's openness to ideas submitted during fraud brainstorming on a scale from 1 (extremely low level of openness) to 7 (extremely high level of openness); to measure fraud brainstorming quality, a dichotomous variable is created which is equal to 1 if the openness is greater than the sample mean; 0 otherwise.

The number of minutes spent in fraud brainstorming; to measure fraud brainstorming quality, a dichotomous variable is created which is equal to 1 if the number of minutes is greater than the sample mean; 0 otherwise.

Dichotomous variables equal to 1 if more than one fraud brainstorming session was held by the engagement team; 0 otherwise.

Dichotomous variables equal to 1 if fraud brainstorming occurred [at the end of the prior year's audit, pre-planning or early in planning]; 0 otherwise.

Number of years, coded as follows: $1=0-4$ years, $2=5-$ 10 years, $3=11-15$ years, $4=>16$ years.

Measure of time budget pressure on a scale from 1 (strongly disagree) to 7 (strongly agree); measured as the sum of the answers to the underlying 3 items. *

The number of years served as an engagement partner for this client, coded as follows: $1=0$ years (first year), $2=$ $1-3$ years, $3=3-7$ years .

The importance of a client on a scale from 1 (not at all important) to 7 (extremely important).

Dichotomous variables equal to 1 if fraudulent financial reporting has been detected at the client during the past three years; 0 otherwise.

The number of engagements the participant served on in which fraudulent financial reporting was identified.

Dichotomous variables equal to 1 if the lead engagement manager changed from the prior year; 0 otherwise. 


Variable Name

MATMISDETECT

MATMISEXP_cat

NOMINAL

OPENDISC

ROUNDROBIN

SENIORCHANGE

TEAMEXP

TEAMSIZE

TONE_AT_TOP

\section{Description}

Dichotomous variables equal to 1 if material misappropriation of assets has been detected at the client during the past three years; 0 otherwise.

The number of engagements the participant served on in which material misappropriation of assets was identified, coded as follows: $1=0$ engagements, $2=1-2$ engagements, $3=>2$ engagements.

Dichotomous variables equal to 1 if the nature of the format of the discussion for fraud brainstorming is nominal; 0 otherwise.

Dichotomous variables equal to 1 if the nature of the format of the discussion for fraud brainstorming is open discussion; 0 otherwise.

Dichotomous variables equal to 1 if the nature of the format of the discussion for fraud brainstorming is round robin; 0 otherwise.

Dichotomous variables equal to 1 if the lead engagement senior changed from the prior year; 0 otherwise.

The perception of the entire engagement team's level of expertise on this client on a scale from 1 (extremely low level of expertise) to 7 (extremely high level of expertise).

Number of financial statement auditors assigned to the engagement, coded as follows: $1=1-5$ auditors, $2=6-$ 10 auditors, $3=11-15$ auditors, $4=16-20$ auditors, $5=>$ 20 auditors.

Sweeney et al. (2010) measure of perceived unethical tone at the top on a scale from 1 (disagree strongly) to 7 (strongly agree); measured as the reverse of the sum of the answers to the underlying 4 items. *

${ }^{*}$ See underlying items in Appendix IV 
APPENDIX III. VARIABLES DEFINITIONS CHAPTER 4

Variable Name

Description

\section{Professional Skepticism Traits}

HPS

Auditor's score on the Hurtt Professional Skepticism Scale.*

HIGH_HPS

Dichotomous variables equal to 1 if auditors scored at or above the median score on the Hurtt Professional Skepticism Scale; 0 otherwise.

$R I T$

Reversed auditor's score on the Rotter Interpersonal Trust Scale.*

HIGH RIT

Dichotomous variables equal to 1 if auditors scored at or above the median, reversed score on the Rotter Interpersonal Trust Scale; 0 otherwise.

\section{Audit Quality Proxies}

GCO

Dichotomous variables equal to 1 if a company received a GCO; 0 otherwise.

EM1

The value of discretionary accruals measured by subtracting non-discretionary accruals of total accruals

EM2

Total accruals.

Control Variables

LNTA

LOSS

$R O A$

INVREC

CURRENT

PROBANKF

The natural logarithm of total assets.

Dichotomous variables equal to 1 if a company has an operating loss; 0 otherwise.

Total equity deflated by total assets.

Inventories and receivables divided by total assets.

Current assets divided by current liabilities.

The score of a standardized bankruptcy prediction model developed for Belgian companies by Ooghe and Spaenjers (2005). In this model, eight variables are logittransformed and then equally weighted: (1) gross added value/personnel employed, (2) net return on total assets before taxes, (3) net return on equity after taxes, (4) selffinancing level, (5) general level of financial independence, (6) short-term financial debt level, (7) free cash flow, and (8) (cash + short-term investments - shortterm financial debt)/current assets. A higher score indicates a healthier company.

INFLUENCE

The ratio of the client's fees for all services to the sum of fees for all clients of the audit office.

BIG4

Dichotomous variables equal to 1 if the audit firm is a Big4 firm; 0 otherwise. 


\begin{tabular}{|c|c|}
\hline Variable Name & Description \\
\hline GENDER & $\begin{array}{l}\text { Dichotomous variables equal to } 1 \text { if the auditor is female; } 0 \\
\text { otherwise. }\end{array}$ \\
\hline LANG & $\begin{array}{l}\text { Dichotomous variables equal to } 1 \text { if the auditor is French } \\
\text { speaking; } 0 \text { otherwise. }\end{array}$ \\
\hline$E X P$ & The experience of the auditor expressed in years. \\
\hline FYE & $\begin{array}{l}\text { Dichotomous variables equal to } 1 \text { if the company has a } \\
\text { December year-end; } 0 \text { otherwise. }\end{array}$ \\
\hline LIST & $\begin{array}{l}\text { Dichotomous variables equal to } 1 \text { if the company is listed; } 0 \\
\text { otherwise. }\end{array}$ \\
\hline SALESG & $\left(\right.$ sales $_{t}-$ sales $\left._{t-1}\right) /$ sales $_{t-1}$ \\
\hline$P P E G$ & $\left(P P E_{t}-P P E_{t-1}\right) / P P E_{t-1}$ \\
\hline OCF & Operating cash flow divided by total assets. \\
\hline SALESVOL & $\begin{array}{l}\text { The natural logarithm of the standard deviation of a } \\
\text { company's sales from year t- } 2 \text { through year t. }\end{array}$ \\
\hline OCFVOL & $\begin{array}{l}\text { The natural logarithm of the standard deviation of a } \\
\text { company's cash flow from operations from year t- } \\
\text { through year t. }\end{array}$ \\
\hline
\end{tabular}


APPENDIX IV. MEASUREMENT SCALES 55

HURTT PROFESSIONAL SKEPTICISM SCALE (HPS) (Cronbach's alpha $=0.84$ )

The Hurtt Professional Skepticism Scale (Hurtt 2010) consists of 30 items scored on a 6-point scale, ranging from 1 (strongly disagree) to 6 (strongly agree). The items of which the scores should be reversed are indicated by $(r)$. A higher total score indicates greater trait skepticism.

1. I often accept other peoples' explanations without further thought. ( $r$ )

2. I feel good about myself.

3. I wait to decide on issues until I can get more information.

4. The prospect of learning excites me.

5. I am interested in what causes people to behave the way that they do.

6. I am confident of my abilities.

7. I often reject statements unless I have proof that they are true.

8. Discovering new information is fun.

9. I take my time when making decisions.

10. I tend to immediately accept what other people tell me. (r)

11. Other peoples' behavior doesn't interest me. ( $r$ )

12. I am self-assured.

13. My friends tell me that I usually question things that I see or hear.

14. I like to understand the reason for other peoples' behavior.

15. I think that learning is exciting.

16. I usually accept things I see, read or hear at face value. ( $r$ )

17. I don't feel sure of myself. ( $r$ )

18. I usually notice inconsistencies in explanations.

19. Most often I agree with what the others in my group think. ( $r$ )

20. I dislike having to make decisions quickly.

21. I have confidence in myself.

22. I don't like to decide until l've looked at all of the readily available information.

23. I like searching for knowledge.

24. I frequently question things that I see or hear.

25. It is easy for other people to convince me. ( $r$ )

26. I seldom consider why people behave in a certain way. ( $r$ )

27. I like to ensure that I've considered most available information before making a decision.

28. I enjoy trying to determine if what I read or hear is true.

29. I relish learning.

30. The actions people take and the reasons for those actions are fascinating.

55 The statistics reported in parentheses relate to the sample of Chapter $2(n=663)$. 
Professional Moral Courage SCALE (PMC) (Cronbach's alpha = 0.91)

The Professional Moral Courage scale (Serkerka et al., 2009) consists of 15 Items scored on a 7-point scale, ranging from 1 (never true) to 7 (always true). Respondents are asked to evaluate these statements as they pertain to them at work. Adding up the points for each item and dividing the total by 15 provides the moral courage score. A higher total score indicates greater moral courage and willingness to take skeptical action.

1. I am the type of person who is unfailing when it comes to doing the right thing at work.

2. When I do my job I regularly take additional measures to ensure my actions reduce harms to others.

3. My work associates would describe me as someone who is always working to achieve ethical performance, making every effort to be honorable in all my actions.

4. I am the type of person who uses a guiding set of principles from the organization as when I make ethical decisions on the job.

5. No matter what, I consider how both my organization's values and my personal values apply to the situation before making decisions.

6. When making decisions I often consider how my role in the organization, my command, and my upbringing must be applied to any final action.

7. When I encounter an ethical challenge I take it on with moral action, regardless of how it may pose a negative impact on how others see me.

8. I hold my ground on moral matters, even if there are opposing social pressures.

9. I act morally even if it puts me in an uncomfortable position with my superiors.

10. My coworkers would say that when I do my job I do more than follow the regulations, I do everything I can to ensure actions are morally sound.

11. When I go about my daily tasks I make sure to comply with the rules, but also look to understand their intent, to ensure that this is being accomplished as well.

12. It is important that we go beyond the legal requirements but seek to accomplish our tasks with ethical action as well.

13. It is important for me to use prudential judgment in making decisions at work.

14. I think about my motives when achieving the mission, to ensure they are based upon moral ends.

15. I act morally because it is the right thing to do. 
ROTTER INTERPERSONAL TRUST SCALE (RIT) (Cronbach's alpha = 0.76)

Rotter's Interpersonal Trust scale consists of 25 items that are scored on a 5-point Likert Scale (varying from strongly disagree to strongly agree). We gathered scale items from Wrightsman (1991). The items of which the scores should be reversed are indicated by ( $r$ ). Adding up the points for each item provides the interpersonal trust score. Higher scores indicate higher interpersonal trust. We use the reversed score on Rotter's Interpersonal Trust Scale to measure distrust; higher scores indicate greater distrust.

1. Hypocrisy is on the increase in our society. ( $r$ )

2. In dealing with strangers one is better off to be cautious until they have provided evidence that they are trustworthy. ( $r$ )

3. This country has a dark future unless we can attract better people into politics. (r)

4. Fear and social disgrace or punishment rather than conscience prevents most people from breaking the law. ( $r$ )

5. Using the honor system of not having a teacher present during exams would probably result in increased cheating. ( $r$ )

6. Parents usually can be relied on to keep their promises.

7. The United Nations will never be an effective force in keeping world peace. $(r)$

8. The judiciary is a place where we can all get unbiased treatment.

9. Most people would be horrified if they knew how much news that the public hears and sees is distorted. ( $r$ )

10. It is safe to believe that in spite of what people say most people are primarily interested in their own welfare. (r)

11. Even though we have reports in newspapers, radio, and TV, it is hard to get objective accounts of public events. ( $r$ )

12. The future seems very promising.

13. If we really knew what was going on in international politics, the public would have reason to be more frightened than they now seem to be. ( $r$ )

14. Most elected officials are really sincere in their campaign promises.

15. Many major national sports contests are fixed in one way or another. ( $r$ )

16. Most experts can be relied upon to tell the truth about the limits of their knowledge.

17. Most parents can be relied upon to carry out their threats or punishments.

18. Most people can be counted on to do what they say they will do.

19. In these competitive times one has to be alert or someone is likely to take advantage of you. ( $r$ )

20. Most idealists are sincere and usually practice what they preach.

21. Most salesmen are honest in describing their products.

22. Most students in school would not cheat even if they sure of getting away with it.

23. Most repairmen will not overcharge even if they think you are ignorant of their specialty.

24. A large share of accident claims filed against insurance companies are phony. ( $r$ )

25. Most people answer public opinion polls honestly. 


\section{PERSONALITY TRAITS}

The Ten-Item Personality Inventory (Gosling et al. 2003) consists of 10 items scored on a 7-point point Likert Scale (varying from strongly disagree to strongly agree). The items of which the scores should be reversed are indicated by ( $r$ ). Adding up the scores results in a score for EXTRAVERSION (1, 6), AGREEABLENESS (2, 7), CONSCIENTIOUSNESS (3, 8), EMOTIONALSTABILITY $(4,9)$ and OPENNESS to experiences $(5,10)$.

Here are a number of personality traits that may or may not apply to you. Please indicate to what degree you agree with the following statements. You should rate the extent to which the pair of traits applies to you, even if one characteristic applies more strongly than the other.

1. Extraverted, enthusiastic.

2. Critical, quarrelsome. $(r)$

3. Dependable, self-disciplined.

4. Anxious, easily upset. ( $r$ )

5. Open to new experiences, complex.

6. Reserved, quiet. ( $r$ )

7. Sympathetic, warm.

8. Disorganized, careless. $(r)$

9. Calm, emotionally stable.

10. Conventional, uncreative. ( $r$ )

The Short Dark Triad (Jones and Paulhus 2014) consists of 27 items scored on a 5-point Likert Scale (varying from strongly disagree to strongly agree). The items of which the scores should be reversed are indicated by $(r)$. The sum of scores indicates MACHIAVELLIANISM (1-9), NARCISSISM (10-18) and PSYCHOPATHY (19-27).

Please indicate to what degree you agree with the following statements.

\section{MACHIAVELLIANISM:}

1. It's not wise to tell your secret.

2. I like to use clever manipulation to get my way.

3. Whatever it takes, you must get the important people on your side.

4. Avoid direct conflict with others because they may be useful in the future.

5. It's wise to keep track of information that you can use against people later.

6. You should wait for the right time to get back at people.

7. There are things you should hide from other people because they don't need to know.

8. Make sure your plans benefit you, not others.

9. Most people can be manipulated.

\section{NARCISSISM:}

10. People see me as a natural leader.

11. I hate being the center of attention. ( $r$ )

12. Many group activities tend to be dull without me.

13. I know that I am special because everyone keeps telling me so.

14. I like to get acquainted with important people.

15. I feel embarrassed if someone compliments me. ( $r$ )

16. I have been compared to famous people.

17. I am an average person. ( $r$ )

18. I insist on getting the respect I deserve. 


\section{PSYCHOPATHY:}

19. I like to get revenge on authorities.

20. I avoid dangerous situations. ( $r$ )

21. Payback needs to be quick and nasty.

22. People often say l'm out of control.

23. It's true that I can be mean to others.

24. People who mess with me always regret it.

25. I have never gotten into trouble with the law. ( $r$ )

26. I enjoy having sex with people I hardly know.

27. I'll say anything to get what I want.

\section{AUDIT KNOWLEDGE}

We measure audit experience with respect to valuation, fraud, and analytical procedures. We use 3 items scored on a 7-point Likert Scale (varying from not at all experienced to extremely experienced). Higher scores indicate greater experience along these dimensions.

Indicate the amount of experience you have with respect to the following issues:

1. Difficult accounting measurement and valuation problems. (KNOW_VALUTATION)

2. The assessment of risks of material misstatements due to fraud. (KNOW_FRAUD)

3. The application of analytical procedures during an audit. (KNOW_ANALYT_PROC)

ATTITUDE (Cronbach's alpha $=0.62$ )

To measure attitude towards professional skepticism, we composed a question consisting of 5 items scored on a 7-point Scale. The items of which the scores should be reversed are indicated by $(r)$. Higher scores indicate a more positive attitude towards professional skepticism.

I think maintaining professional skepticism throughout an audit engagement is:

1. good - bad. $(r)$. Mean $=6.49$; Factor loading $=0.79$

2. harmful - beneficial. Mean $=5.87$; Factor loading $=0.62$

3. pleasant (for me) - unpleasant (for me). $(r)$. Mean $=5.44$; Factor loading $=0.48$

4. difficult - easy. Mean $=4.11$; Factor loading $=0.18$

5. unimportant - important. Mean $=6.49$; Factor loading $=0.60$

SUBJECTIVE NORM (SN) (Cronbach's alpha $=0.71)$

We measure subjective norm based on the work of Ajzen (1991, 2006), including 3 items scored on a 7-point Likert Scale (varying from strongly disagree to strongly agree). Higher scores indicate greater perceived social pressure to engage in skeptical behavior.

To what extent do you agree with the following statements?

1. Most people who are important to me within my firm would encourage me to maintain professional skepticism throughout an audit. Mean $=5.79$; Factor loading $=0.64$.

2. Most people like me maintain professional skepticism throughout an audit. Mean $=5.71$; Factor loading $=0.73$.

3. It is expected of me that I maintain professional skepticism throughout an audit. Mean = 6.18; Factor loading $=0.67$. 
PERCEIVED BEHAVIORAL CONTROL (PBC) (Cronbach's alpha $=0.34$ )

We measure perceived behavioral control based on the work of Ajzen $(1991,2006)$, including 3 items scored on a 7-point Likert scale (varying from strongly disagree to strongly agree). Higher scores indicate a greater sense of perceived behavioral control.

To what extent do you agree with the following statements?

1. Maintaining professional skepticism throughout an audit or not is entirely up to me. ( $r$ ) Mean $=4.07 ;$ Factor loading $=0.25$.

2. I am confident that I can maintain professional skepticism throughout an audit. Mean $=5.89$; Factor loading $=0.15$.

3. Maintaining professional skepticism throughout an audit is beyond my control. $(\mathrm{r})$ Mean $=$ 5.30; Factor loading $=0.94$.

\section{AUDIT FIRM TONE AT THE TOP}

We measure the relative extent of audit firm ethical tone at the top based on Sweeney et al. 2010, whereby the measure consists of 4 items scored on a 7-point Likert scale (varying from strongly disagree to strongly agree). The items of which the scores should be reversed are indicated by $(r)$. We use the reversed score to measure tone at the top. Higher scores indicate a more ethical perceived tone at the top.

To what extent do you agree with the following statements?

1. In my firm, I sometimes perceive that senior managers engage in behaviors that I consider to be unethical. $(r)$ Mean $=5.45$

2. In my firm, I sometimes perceive that partners engage in behaviors that I consider to be unethical. (r) Mean $=5.36$

3. In my firm, top management has let it be known in no uncertain terms that unethical behaviors will not be tolerated. Mean $=5.47$

4. My firm is known as a leader in promoting professional ethics within the profession. Mean = 5.08

\section{TIME BUDGET PRESSURE}

Time budget pressure consists of 3 items scored on a 7-point Likert Scale (varying from strongly disagree to strongly agree). The items of which the scores should be reversed are indicated by $(r)$. Adding up the scores results in a score for perceived pressure. Higher scores indicate a higher perceived pressure.

To what extent do you agree with the following statements?

1. I felt pressure from the budget I was working on. Mean $=3.43$

2. I felt that the time budget was unattainable. Mean $=3.59$

3. I finished my work within the allotted time budget. $(r)$ Mean $=4.18$ 


\section{SKEPTICAL ACTIONS}

We measure skeptical action using nine questions based on the work of Robinson et al. (2017), including nine items scored on a 7-point scale (varying from strongly disagree to strongly agree). Higher scores indicate greater levels of skeptical action on the audit engagement.

\section{SEARCHING FOR INFO (Cronbach's alpha =0.78)}

1. I actively sought out all of the information that I could. Mean $=5.52$; Factor loading $=0.73$

2. I used all resources available to me to get all of the information that I could. Mean $=5.64$; Factor loading $=0.65$

\section{QUESTIONING (Cronbach's alpha $=0.77)$}

3. I had a tendency to reject statements unless I had proof that they were true. Mean $=5.28$; Factor loading $=0.68$

4. I frequently questioned the things that I saw or read. Mean $=5.59$; Factor loading $=0.79$

5. I tended to question the statements that I read from this client. Mean $=5.30$; Factor loading $=0.72$

\section{SUSPENDING JDGMT (Cronbach's alpha $=0.84$ )}

6. I tried to ensure that I had considered most available information before making a decision. Mean $=5.86 ;$ Factor loading $=0.79$

7. I did not like deciding until $I$ had a chance to look at all of the available information. Mean = 5.61 ; Factor loading $=0.68$

8. I took my time when making decisions. Mean $=5.69$; Factor loading $=0.81$

9. I waited to make decisions until I could get more information. Mean $=5.56$; Factor loading $=$ 0.75 


\section{VALORIZATION ADDENDUM}

The objective of an external audit is to provide assurance to the users of financial statements on the quality of the reported information. A quality audit is therefore essential for the functioning of capital markets. The exercise of professional skepticism is often described as a key input for a quality audit. However, despite its alleged importance, our understanding of professional skepticism remains limited and underdeveloped due to the lack of prior research that simultaneously considers the impact of personal and situational characteristics. Professional skepticism traits, along with personal (e.g., knowledge, experience) and situational characteristics (e.g., tone at the top, time budget pressure, audit firm), affect the auditor's behavior. In order to advance our understanding of professional skepticism, this dissertation investigates professional skepticism traits as input factors, and as drivers of process and output factors of the audit. The focus of this dissertation is thus on the inherent professional skepticism of the auditor (i.e., professional skepticism traits), but personal and situational characteristics are incorporated to be able to make a distinction between the effect of trait and state skepticism.

Results of this dissertation show that professional skepticism traits of auditors are associated with personality traits and other individual differences, and differ significantly across ranks. Further, this dissertation shows that professional skepticism ultimately affects audit quality as professional skepticism traits are significant drivers of certain audit processes and output factors. The findings from this dissertation can inform, amongst others, audit firms, auditors, and standard setters.

Specifically, the findings in Chapter 2 show that professional skepticism traits are affected by personality and individual differences. Finding the right personality fit for the auditing profession, therefore, seems important. These findings are of interest for both (future) auditors and audit firms. People might want to think about the person-job fit before pursuing a career in auditing. Certain personality traits (such as professional skepticism traits) are important in auditing practice (e.g., Cohen et al. (2017) show that people with lower trust are more likely to leave the profession). Hence, audit firms are recommended to assess personality during personnel screening and selection (e.g., by the use of personality tests) to ultimately attract and retain professionals that are able to take skeptical actions as the standards and regulators require. Further, the analyses in Chapter 2 include situational characteristics and the results show that subjective norms (i.e., social pressure) are the strongest predictor of auditors' intentions to act skeptically. Subjective norms relate to how individuals feel about and respond to pressure from others. These findings could assist auditors and audit firms with designing effective interventions to improve auditors' 
professional skepticism. The exercise of professional skepticism throughout an audit could be encouraged by engagement team members, with managers and partners leading by example.

The findings in Chapter 3, which investigates professional skepticism traits as a driver of fraud brainstorming quality, are also relevant for practitioners. First, the results provide valuable insights regarding fraud brainstorming quality and the underlying items across professional skepticism traits partitions. Based on these findings, actions to improve fraud brainstorming quality can be recommended. More specifically, engagement team leaders might want to have a high attendance rate of specialists, a high contribution of all team members (especially forensic specialists), and an extensive discussion about how management might perpetrate fraud during the fraud brainstorming session. Furthermore, the results suggest that the effect of professional skepticism traits on fraud brainstorming is positive in audit firms with a positive performance evaluation system (i.e., a system that rewards professional skepticism). Audit firms and engagement leaders might want to take that into account when selecting the evaluation system. A well-designed evaluation and reward system can foster the exercise of professional skepticism.

Finally, Chapter 4 examines how professional skepticism traits influence the auditor's reporting behavior. The findings show that more skeptical auditors are more likely to issue a GCO and that situational characteristics rarely influence the effects of professional skepticism traits on the likelihood of expressing a GCO. These results suggest that situations in auditing provide ample room for personality to play its role. These findings again speak to the importance of finding the right personality fit for the profession.

Overall, the findings of this dissertation can help to enhance the exercise of professional skepticism in audit practice, with the ultimate goal to improve audit quality. In particular, the dissertation provides insights that the inherent professional skepticism of the auditor is an important input to a quality audit, and that situational characteristics (e.g., social pressure, tone at the top, evaluation and reward systems) can enhance the exercise of professional skepticism. 


\section{CURRICULUM VITAE}

Sanne Janssen was born on November $6^{\text {th }}$, 1989 in Borgerhout, Antwerp, Belgium. She studied Applied Economic Sciences: Business Administration at the University of Antwerp and obtained her Master of Science degree with specialization Accounting (magna cum laude) in June 2011. She was employed as a research and teaching assistant at the University of Antwerp for one year before joining the PhD program of the department of Accounting and Finance at the same institution in September 2012. In 2014, she also became a PhD candidate at the Accounting and Information Management department at Maastricht University. Because of the joint-PhD, she visited Maastricht University a few months every year during her doctoral studies. Further, she was a visiting scholar at the University of Wisconsin-Madison in the Fall of 2018. Since September 2019 she works as a Lecturer at the Open University in Heerlen, the Netherlands.

Her work was presented at various international conferences such as the midyear meeting of the Auditing Section of the American Accounting Association (AAA), the International Symposium on Auditing Research (ISAR), the European Auditing Research Network (EARNet), the Annual Congress of the European Accounting Association (EAA), and workshops at the University of Wisconsin-Madison, KU Leuven, and the Open University.

She is co-recipient of three grants from the Foundation for Auditing Research (FAR) in 2016, 2018, and 2020. She presented her work at FAR conferences and a FAR Masterclass. 